Portland State University

PDXScholar

6-10-1993

\title{
Hydrogeochemical Characterization of the Alvord Valley Known Geothermal Resources Area, Harney County, Oregon
}

Anna Maria St. John

Portland State University

Follow this and additional works at: https://pdxscholar.library.pdx.edu/open_access_etds

Part of the Environmental Sciences Commons, and the Geology Commons Let us know how access to this document benefits you.

Recommended Citation

St. John, Anna Maria, "Hydrogeochemical Characterization of the Alvord Valley Known Geothermal Resources Area, Harney County, Oregon" (1993). Dissertations and Theses. Paper 2678.

https://doi.org/10.15760/etd.2674

This Thesis is brought to you for free and open access. It has been accepted for inclusion in Dissertations and Theses by an authorized administrator of PDXScholar. Please contact us if we can make this document more accessible: pdxscholar@pdx.edu. 
AN ABSTRACT OF THE THESIS of Anna Maria St. John for the Master of Science in Geology/Geohydrology presented June $10,1993$.

Title: Hydrogeochemical Characterization of the Alvord Valley Known Geothermal Resources Area, Harney County, Oregon

APPROVED BY MEMBERS OF THE THESIS COMMITTEE:

Michael L. Cumnings, Chair

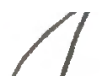

Marvin H. Beeson

Ansel G. Johnston

Leonard G. Swanson

The Alvord Valley Known Geothermal Resources Area (KGRA), located east of the Steens Mountain-Pueblo Mountains fault block in southeastern Oregon, is within the northern 
Basin and Range province. This investigation focuses on three thermal areas in the Alvord Basin: Borax Lake and the hot springs north of Borax Lake, Alvord Hot Springs and Mickey Springs.

Mickey Springs and the springs north of Borax Lake are boiling at the surface (94 and $95^{\circ} \mathrm{C}$, respectively). Inflow temperatures to Borax Lake, measured at a depth of $30 \mathrm{~m}$, are greater than $100^{\circ} \mathrm{C}$. Surface temperatures for Alvord Hot Springs and a flowing well northeast of Borax Lake are 78 and $59^{\circ} \mathrm{C}$, respectively.

Thermal fluids issue from Quaternary lacustrine and alluvial deposits. While silica sinter deposits are present at all three thermal areas, sinter is not presently being deposited. Minor calcite is being deposited at the springs north of Borax Lake. The springs discharge from $N$ to NEstriking, high-angle, basin-bounding faults along the base of Steens Mountain and Mickey Mountain and NE-striking intrabasinal faults south of Alvord Lake.

The thermal waters are dilute sodium-bicarbonate waters with significant amounts of sulfate and chloride.

Conservative element plots (B, F, and Li vs. Cl) indicate good correlation between $\mathrm{Cl}$ and the other conservative elements. These correlations could result from mixing of thermal water with a dilute cold water or fluid evolution due to increased fluid-rock interaction, evaporation, and steam loss due to boiling. The small variations in chloride 
concentrations of thermal fluids during the sampling period argues against mixing of thermal fluids with cold water. The geothermal system is a hot-water rather than a vapordominated system.

The $6 \mathrm{D}$ content of thermal fluids is similar to the $6 \mathrm{D}$ content of local cold water wells, springs, basinal pore fluids at a depth of 4 to $5 \mathrm{~m}$, and perennial streams. Similarities in $\delta D$ values indicate recharge for geothermal fluids is precipitation from the steens Mountain fault block. The $6^{18} \mathrm{O}$ content of thermal fluids is shifted 2 to $3 \%$ to the right of the world meteoric water line indicating fluid-rock interaction at elevated temperatures in the reservoir.

Tritium contents indicate relatively long residence times and/or low-velocity circulation of meteoric water through basement rocks. Values range from 0 to 0.25 T.U. The application of two end-member models, which calculate fluid residence times, generate a minimum of 57 years and a maximum of greater than 10,000 years.

Estimated reservoir temperatures based on cation and silica geothermometry are between 170 and $200^{\circ} \mathrm{C}$. Oxygensulfate isotope geothermometer estimates indicate reservoir temperatures between 198 and $207^{\circ} \mathrm{C}$ for Borax Lake and Alvord Hot Springs. Mickey Springs and a flowing well northeast of Borax Lake yield temperature estimates of 168 and $150^{\circ} \mathrm{C}$, respectively. These values indicate partial 
reequilibration of the isotopic system.

The $\delta^{13} \mathrm{C}$ contents of carbon dioxide and methane of gas discharges from the thermal areas are similar to geothermal fluids from other sites. The $\delta^{13} \mathrm{C}$ of methane indicate "normal" geothermal methane for Alvord Hot Springs and Mickey Springs $\left(-27.8\right.$ and -27.6 , respectively). The $\delta^{13} \mathrm{C}$ of $\mathrm{CH}_{4}$ for springs north of Borax Lake $(-33.6)$ indicates a small amount of thermogenic methane may be contributed by thermal alteration of organics in basinal sediments. The $\delta^{13} \mathrm{C}$ contents for $\mathrm{CO}_{2}$ at Alvord Hot Springs and Borax Lake are within the range expected for atmospheric, fumarolic, or mantle derived $\mathrm{CO}_{2}\left(-6.5\right.$ and -6.6 , respectively). The $\delta^{13} \mathrm{C}$ content of $\mathrm{CO}_{2}$ from Mickey Springs is isotopically lighter than gas released from fumaroles or the mantle (-9.4). $\mathrm{N}_{2} /$ Ar ratios for Mickey Springs and Borax Lake gases (39.2 and 40.8 , respectively) indicate interaction with airsaturated ground water during flow through the the zone of aeration. Helium is enriched relative to $\mathrm{Ar}$ and $\mathbf{N}_{2}$ in gas discharges from Alvord Hot Springs, indicating longer fluid residence times and/or increased crustal interaction at high temperatures.

Ratios of $\mathrm{B} / \mathrm{Cl}$ indicate the fluid reservoir is hosted in volcanic rocks. The Li/Cs ratios for the Borax Lake thermal area are consistent with a reservoir located in rhyolitic rocks. The ${ }^{228} \mathrm{Ra} /{ }^{226} \mathrm{Ra}$ content of Borax Lake thermal fluids $(1.14 \pm 0.13 \mathrm{dpm} / \mathrm{kg})$ indicates interaction 
with volcanic rocks for Borax Lake. The ${ }^{228} \mathrm{Ra} /{ }^{226} \mathrm{Ra}$ content of thermal fluids from Alvord Hot Springs and Mickey Springs $(0.38 \pm 0.02$ and $0.17 \pm 0.09)$ are lower than those expected for volcanic rocks and may indicate local uranium accumulation in the reservoir or zones of upflow. The ${ }^{87} \mathrm{Sr} /{ }^{86} \mathrm{Sr}$ values for thermal waters and stratigraphic units indicate the fluid reservoir is located in volcanic rocks beneath Steens Basalt. Equilibration of fluids in these units argues for thermal water circulation depths of 2 to $2.5 \mathrm{~km}$ in the Borax Lake thermal area, greater than $3 \mathrm{~km}$ in the Alvord Hot Springs area and 1 to $2 \mathrm{~km}$ in the Mickey Springs area.

Data presented in this study do not preclude a single large deep reservoir system discharging at these three thermal areas in the Alvord basin. Differences in the chemical and isotopic composition of discharge from the three thermal areas are produced during upflow from the reservoir. During upflow, thermal waters follow a complex pathway of vertical and lateral fractures which includes short residence times in shallow reservoirs before reaching the surface. Boiling, mixing with condensate, oxidation, mixing with 1-38 tritium-bearing, near-surface cold water, relative differences in flow rate and volume, and slow cooling without vigorous boiling are processes that modify fluid composition during upflow from the deep geothermal reservoir. 
HYDROGEOCHEMICAL CHARACTERIZATION OF THE

ALVORD VALLEY KNOWN GEOTHERMAL RESOURCES AREA, HARNEY COUNTY, OREGON

by

ANNA MARIA ST. JOHN

A thesis submitted in partial fulfillment of the requirements for the degree of

\author{
MASTER OF SCIENCE \\ in \\ GEOLOGY/GEOHYDROLOGY
}

Portland State University

1993 
TO THE OFFICE OF GRADUATE STUDIES:

The members of the Committee approve the thesis of Anna Maria St. John presented June 10, 1993.

Michae 1 L. Cummings,

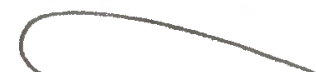

Michael L. Cummings,

Cnarr L

Marvin H. Beeson

Ansel $\mathrm{G}$. Johŕson

Leonaref G. Swanson

APPROVED:

-Anse1 G. Jønnson, Cnair, vepartment of Geology

Roy W. Koch, Vice Provost for Graduate Studies and Research 
DEDICATION

This thesis is dedicated to the memory of Michael Cummings' appendix. 


\section{ACKNOWLEDGEMENTS}

This thesis would not have been completed without the support, advice, patience and sense of humor of several wonderful people. Many thanks to George Darr and the Bonneville Power Administration for financial support. Denny Seymour and Nancy Katrinos of the Bureau of Land Management provided the impetus for this project, as well as technical support and helpful discussions. Randy Thompson, Tim Blackwood and Dave Whitaker supplied their brains and braun in the field. Randy Thompson also provided his G.I.S. wizardry and drafting skills for the enclosed maps. Many thanks to Rodger, Ray and Marie West for the use of Flipper for our Borax Lake adventures. I would like to thank Neil sturchio for a critical review of the thesis. Many thanks to all of my buddies in Manzanita and Portland for their emotional support over the years. Many thanks to the people of the Alvord and Pueblo Valleys, including the Northrops, the Davis family, Carl Thomas, Mike and Tracy of the Kueny Ranch and Jim Weston for their kindness and water. Lastly, I would like to thank my friend and advisor, Michael Cummings for intelligent discussions and critical reviews, his keen sense of observation in the field, and his patience and sense of humor during this project. 
TABLE OF CONTENTS

PAGE

ACKNOWLEDGEMENTS ....................... iii

LIST OF TABLES......................... vii

LIST OF FIGURES.......................

INTRODUCTION ........................... 1

REGIONAL TECTONIC AND GEOLOGIC SETTING.......... 5

stratigraphy........................ 10

Pre-Tertiary Rocks

Tertiary Rocks

Quaternary Deposits

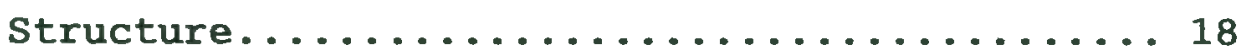

REGIONAL HEAT FLOW...................... 21

REGIONAL HYDROLOGIC SETTING................ 27

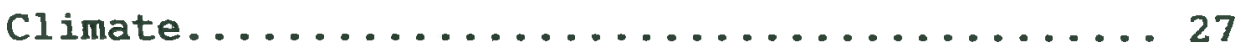

Hydrology .......................... 28

Ground Water Flow

Deep Thermal Water Flow

Surface Hydrology

SAMPLING AND ANALYSIS.................... 33

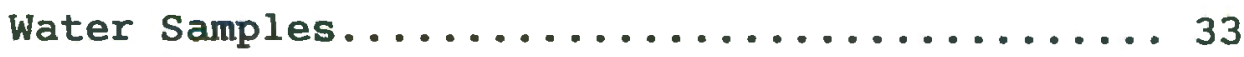

Gas Samples........................ 35

LITHOLOGY OF HOT SPRING AREAS............... 38

Borax Lake.......................... 39

Surface Features

Lithology 
Mickey Springs.................. 43

Surface Features

Lithology

Alvord Hot Springs................ 50

Surface Features

Lithology

STRUCTURAL CONTROLS ON THE LOCATION OF HOT SPRINGS. 55

Borax Lake.................... 55

Mickey Springs.................. 59

Alvord Hot Springs.................61

GEOTHERMAL RESERVOIR CONDITIONS........... 63

Chemistry of Non-thermal and Thermal Waters... 63

Temporal Variations in Water Chemistry

Chemistry of Non-thermal waters

Chemistry of Thermal Waters

Light Isotope Geochemistry............ 80

Oxygen and Deuterium

Tritium

Chemistry of Gas Discharges............. 101

Host Lithology of the Reservoir......... 107

Strontium Isotope Geochemistry

Radium Isotope Geochemistry

Carbon Isotope Geochemistry

Reservoir Geothermometry............. 117

Reservoir Temperatures

DISCUSSION........................ 128

Hydrogeochemistry and Reservoir

Characteristics.............. 129

Recharge

Residence Times in the Reservoir 
PAGE

\author{
Reservoir Temperature \\ Host Rock Lithology \\ Upf low \\ Depth of Thermal Fluid Circulation \\ Conceptual Model of Thermal Fluid \\ Circulation in the Alvord Basin.... 147 \\ SUMMARY AND CONCLUSIONS.................... 151

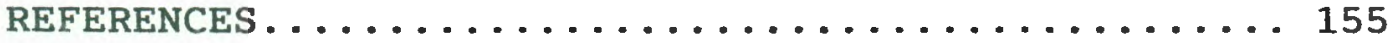

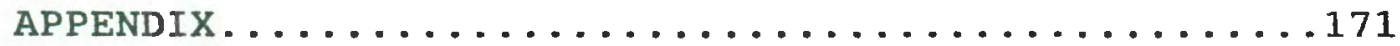




\section{LIST OF TABLES}

PAGE

TABLE

I Stratigraphy Exposed in the Alvord

Basin and Surrounding Mountains.. 11

I Determination of Heat Flow for the

Alvord Basin............... 25

II Chemical Composition of Cold water

Springs and Wells in the Alvord Basin..................... 65

IV Chemical Composition of Thermal Springs

in the Alvord Basin......... 66

V Seasonal Variations in Chloride

Concentrations in Cold Water

Springs and Wells and Thermal

Springs in the Alvord Basin.....70

VI Stable-isotope Composition of Thermal and

Non-thermal Water in the Alvord

Basin..................... 85

VII Tritium Concentrations and estimated

Mean Residence Times for Thermal

Springs and Cold Water Wells and

Springs in the Alvord Basin.....995 
VII Weighted Mean Tritium Values from

Precipitation in Selected Areas of

the Western United States...... 97

IX Chemistry of Alvord Basin Gas

Discharges................. 103

X Strontium Isotope Ratios for Volcanic

Rocks and Thermal Fluids from

the Alvord Basin and Surrounding

Mountains.................. 110

XI Radium Isotope Ratios for Thermal

Fluids from the Alvord Basin.... 113

XII Equations Expressing the Temperature

Dependence of Selected

Geothermometers (After

Fournier, 1981).............. 120

XIII Chemical, Isotopic and Gas

Geothermometry for the

Alvord Valley KGRA............ 123

XIV Chemistry of Thermal and Non-thermal

Water in the Alvord

Basin, 1953 - $1989 \ldots \ldots \ldots \ldots \ldots 172$

XV Fluid-Mineral Equilibria for Cold Waters

in the Alvord Basin........... 174

XVI Saturation Indices $\left(\log \left(I A P / K_{\mathbf{s p}}\right)\right)$ for

Thermal Fluids.............. 175 
XVII Geochemistry of Pore Fluids from

Alvord Lake................ 177 


\section{LIST OF FIGURES}

FIGURE

PAGE

1. Location Map of the Alvord Valley Known Geothermal Resources Area........ 3

2. Tectonic Setting of Southeastern Oregon (Modified from Langer, 1991)......6 6

3. Physiographic setting of the Study Area (Modified from Hart and Carlson, 1987).............. 8

4. Generalized Stratigraphy of Steens Mountain and Alvord Basin (Modified from Orr et al., 1992)................... 12

5. Heat Flow in Nevada and Surrounding

Areas (From Blackwell, 1983)...... 22

6. Idealized Sketch of Fluid Potential

Relationships in Great Basin Flow

Systems (From Mifflan, 1988)....... 29

7. Geology of the Borax Lake Thermal Area... 40

8. Geology of the Mickey Springs Area...... 44

9. Geology of the Alvord Hot Springs Area... 52 
10. Seasonal Variations in Fluid Chemistry

for Cold Waters: a) Major

Constituents, Thomas Well, b) Minor

Constituents, Thomas Well, c) Chemical

Constituents, Alvord Ranch Spring,

d) Chemical Constituents, Alvord

Ranch Well, e) Major Constituents,

Kurtz Well, f) Minor Constituents,

Kurtz Well, g) Major Constituents,

Unnamed Spring North of Mickey

Springs, and h) Minor Constituents,

Unnamed Spring North of Mickey

Springs...............6 67

11. Seasonal Variations in Chemistry of

Thermal Fluids: a) Major

Constituents, Borax Lake,

b) Minor Constituents, Borax Lake,

c) Major Constituents, Springs

North of Borax Lake, d) Minor

Constituents, Springs North of Borax

Lake, e) Major Constituents, Alvord

Hot Springs, f) Minor Constituents,

Alvord Hot Springs, g) Major

Constituents, Mickey Springs, 
and $\mathrm{h}$ ) Minor Constituents, Mickey springs.................668

12. Schoeller Diagram for Cold water

Chemistry................. 71

13. Schoeller Diagram of Thermal

water Chemistry............. 75

14. Relative $\mathrm{Cl}, \mathrm{SO}_{4}$ and $\mathrm{HCO}_{3}$ Contents

of Thermal Fluids on a Weight

Basis $(\mathrm{mg} / \mathrm{kg}) \ldots \ldots \ldots \ldots \ldots \ldots 76$

15. Plots of B, F, and Li vs, Cl for Thermal

and Non-thermal Waters from Alvord

Basin.................... 78

16. Map of North America Showing Contours

of the Approximate $\delta D$ Values of

Meteoric Surface Waters (Taylor,

$1974) \ldots \ldots \ldots \ldots \ldots \ldots \ldots \ldots \ldots$. . . . 82

17. Plot of $\delta D$ vs. $\delta^{18} \circ$ Showing Thermal

and Cold Waters Relative to

WMWL (World Meteoric Water Line)

and SMOW (standard Mean Ocean

water) $\ldots \ldots \ldots \ldots \ldots \ldots \ldots \ldots 68$

18. Seasonal variations in $\delta \mathrm{D}$ and $\delta^{18} \mathrm{O}$

Contents for Cold Waters.........88 88

19. Seasonal Variations in $\delta \mathrm{D}$ and $\delta^{18} 0$

Contents for Thermal Fluids.......89 89 
20. Tritium Models for Alvord Basin

Cold and Thermal waters......... 99

21. Relative $\mathrm{N}_{2}, \mathrm{CH}_{4}$ and $\mathrm{CO}_{2}$ Contents in

Gas Discharges on a Molar

(Volume) Basıs................ 104

22. Relative $N_{2}, H e$ and Ar Contents in

Gas Discharges on a Molar

(Volume) Basıs...................106

23. ${ }^{87} \mathrm{Sr} /{ }^{86} \mathrm{Sr}$ Ratios for Thermal waters

and Country Rocks of the Alvord

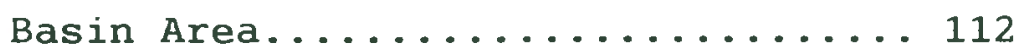

24. Gas Sources Determined from Carbon Isotope

Ratios of Methane and Carbon Dioxide

(Adapted from whiticar, 1990)..... 115

25. Schematic Section through a Hypothetical

Hot-Spring System............. 138

26. Depth vs. Boiling Curve for Water-dominated

Fluids (From Truesdell, 1985)..... 141

27. Schematic Block Diagram Showing

Conceptual Model of Thermal

Fluid Circulation in the Alvord

Basin....................... 149 


\section{INTRODUCT ION}

The geochemistry and isotopic characteristics of thermal fluids and rocks are used to assess the nature and extent of geothermal systems. Tritium and isotopic ratios of $\mathrm{O}, \mathrm{H}, \mathrm{B}, \mathrm{Sr}, \mathrm{S}, \mathrm{Ra}$ and $\mathrm{U}$ are used as tracers of subsurface flow-paths and indicators of residence times, water-rock interactions, and mixing and boiling relations (e.g. White, 1970; Fournier and Truesdel1, 1974; Truesdell and Hulston, 1980; Fournier and Hanshaw, 1986; Shevenell et a1., 1987; Taylor and Stewart, 1987; Kharaka et al., 1990; Palmer and Sturchio, 1990; Parry and Bowman, 1990; Goff et al., 1991a; Sorey et al., 1991; Sturchio, 1990; Sturchio et al., 1993). The chemical and isotopic characteristics of gases are used to delineate the origin of fluids discharged from geothermal systems (e.g. Giggenbach, 1986; White et al. 1990).

In addition, the geochemistry and isotopic composition of thermal fluids are used to determine the reservoir temperatures and lithology of reservoir rocks. The composition of thermal fluids is used to estimate underground reservoir temperatures (Fournier and Rowe, 1966; Fournier and Truesdel1, 1974; Benjamin et al., 1983; Fournier, 1979; Giggenbach, 1988; Kharaka and Mariner, 1989). The Sr-isotope geochemistry of thermal waters and 
rocks is used to determine the lithology of the source reservoir in which fluids initially equilibrated (e.g. Goff et al., 1991). Also, age determinations of hot-spring deposits offer direct information about the timing of thermal activity and the evolution of a geothermal system (e.g. Sorey et al., 1991; Sturchio, 1990; Sturchio and Binz, 1988).

Hot springs are located at three main areas in the Alvord basin in southeastern Oregon: Borax Lake, Alvord Hot Springs and Mickey Springs (Figure 1). The U.S. Geological Survey designated a large portion of this closed basin as a Known Geothermal Resource Area (KGRA) in 1979. The KGRA covers most of the valley floor from Fields to northeast of Mickey Springs (Figure 1). Borax Lake and associated hot springs are located in Pueblo Valley, while Alvord Hot Springs and Mickey Springs are located in the Alvord Valley to the north (Figure 1).

Private companies have conducted geothermal exploration programs throughout the valley including gravity, magnetic, magnetotelluric, seismic reflection and resistivity surveys, contour heat-flow maps, as well as shallow- and deeptemperature gradient drilling and fluid sampling. However, much of this information is proprietary.

This study uses a multidisciplinary approach integrating geologic, geochemical and isotopic data from fluids, gases and rocks to estimate the temperature and 


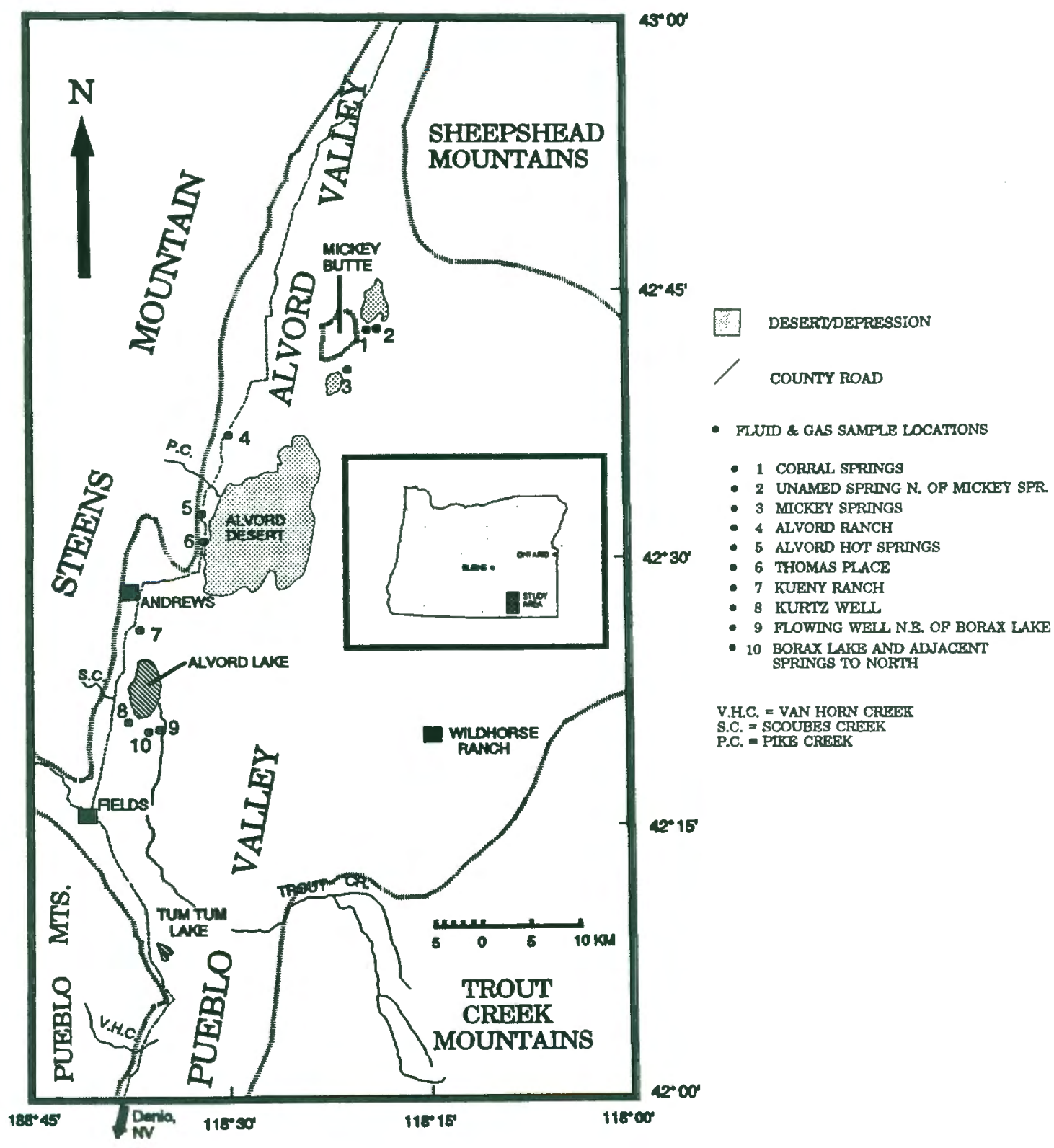

Fiqure 1. Location map of the Alvord Valley Known Geothermal Resources Area. 
extent of underlying reservoirs, to evaluate reservoir rock types, to define possible recharge zones, circulation pathways and mixing relations, and to constrain the hydrologic connection, if any, among Borax Lake, Alvord Hot Springs and Mickey Springs thermal areas. 
REGIONAL TECTONIC AND GEOLOGIC SETTING

The Alvord basin is located about $115 \mathrm{~km}$ southsoutheast of Burns in Harney County, Oregon (Figure 1). The valley is a N-NE striking graben $112 \mathrm{~km}$ long and $13 \mathrm{~km}$ wide at it widest point near Alvord Lake. The broad, flat basin floor lies between the upthrown blocks of Steens Mountain and the Pueblo Mountains to the west and the topographically lower White Horse and Trout Creek Mountains to the southeast. To the northeast, the valley is bounded by lower elevation rolling hills and plateaus more typical of Owyhee Upland topography. At the extreme north and northeast, the Alvord Valley narrows and merges into the Sheepshead Mountains. The Steens Mountain fault block is bounded by the NW-striking Brothers fault zone to the north. To the south, the Steens Mountain is separated from the Pueblo Mountains by a NW-striking normal fault (Figure 2).

Considerable topographic relief exists in this area; Steens Mountain reaches 2,961 m while the Alvord Desert lies at 1,219 m. Suggested displacements on the Steens MountainPueblo Mountains range-front faults on the west vary from $2,555 \mathrm{~m}$ to $2,926 \mathrm{~m}$, with the greatest amounts of movement being at Steens Mountain west of the Alvord Desert (Hemphill-Haley et al., 1989). This displacement suggests a long-term slip rate of $0.33 \mathrm{~mm} / \mathrm{yr}$ for the last $9.3 \mathrm{Ma}$ 


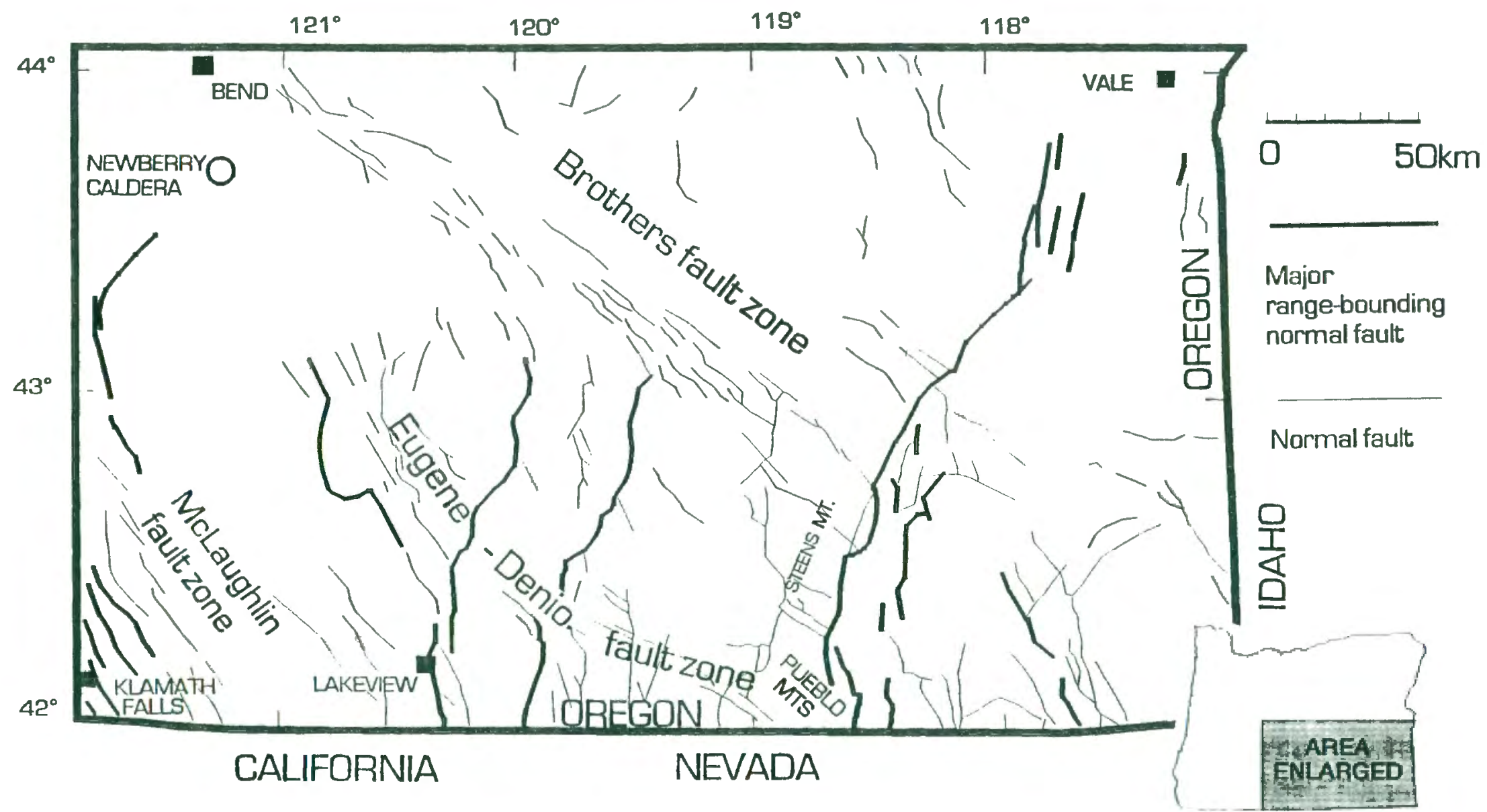

Figure 2. Tectonic setting of southeastern Oregon (Modified from Langer, 1991). 
(Hemphill-Haley et al., 1989). On the eastern side, displacement on the range-front faults are at least $325 \mathrm{~m}$ and may exceed $1,200 \mathrm{~m}$.

The Alvord basin is in the northern part of the Basin and Range province (Baldwin, 1976). The Oregon Plateau (Figure 3 ), the northernmost portion of the Great Basin and Basin and Range province, has been characterized by NW-SE extension over the past 6-14 Ma as evidenced by abundant $\mathrm{N}-$ NE-striking faults (e.g, Steens Mountain, Hart Mountain, Abert $\mathrm{Rim}$ ) along which vertical displacements are up to $2 \mathrm{~km}$ (Hart and Carlson, 1987). West- to northwest-striking normal faults (e.g., Vale fault zone, Brothers fault zone, Eugene-Denio fault zone, McLoughlin fault zone) are interpreted to indicate right-lateral, strike-slip faulting with tens of kilometers of offset caused by $E-W$ extension of the plateau (Lawrence, 1976) (Figures 2 and 3 ).

The Oregon Plateau is bordered on the west by the Paleozoic to Mesozoic rocks of the northern Klamath Mountains and the Cenozoic volcanic rocks of the Cascade Range. To the north the plateau borders the Paleozoic to Mesozoic accreted terrains exposed in the Blue Mountains and Tertiary volcanic rocks of the Columbia Plateau.

Structural features define the southern and eastern margins of the Oregon Plateau. The NW-striking, $200 \mathrm{~km}$ long, 5-km wide zone of normal faults known as the Orevada rift, the northern boundary of the exposed pre-Cenozoic 


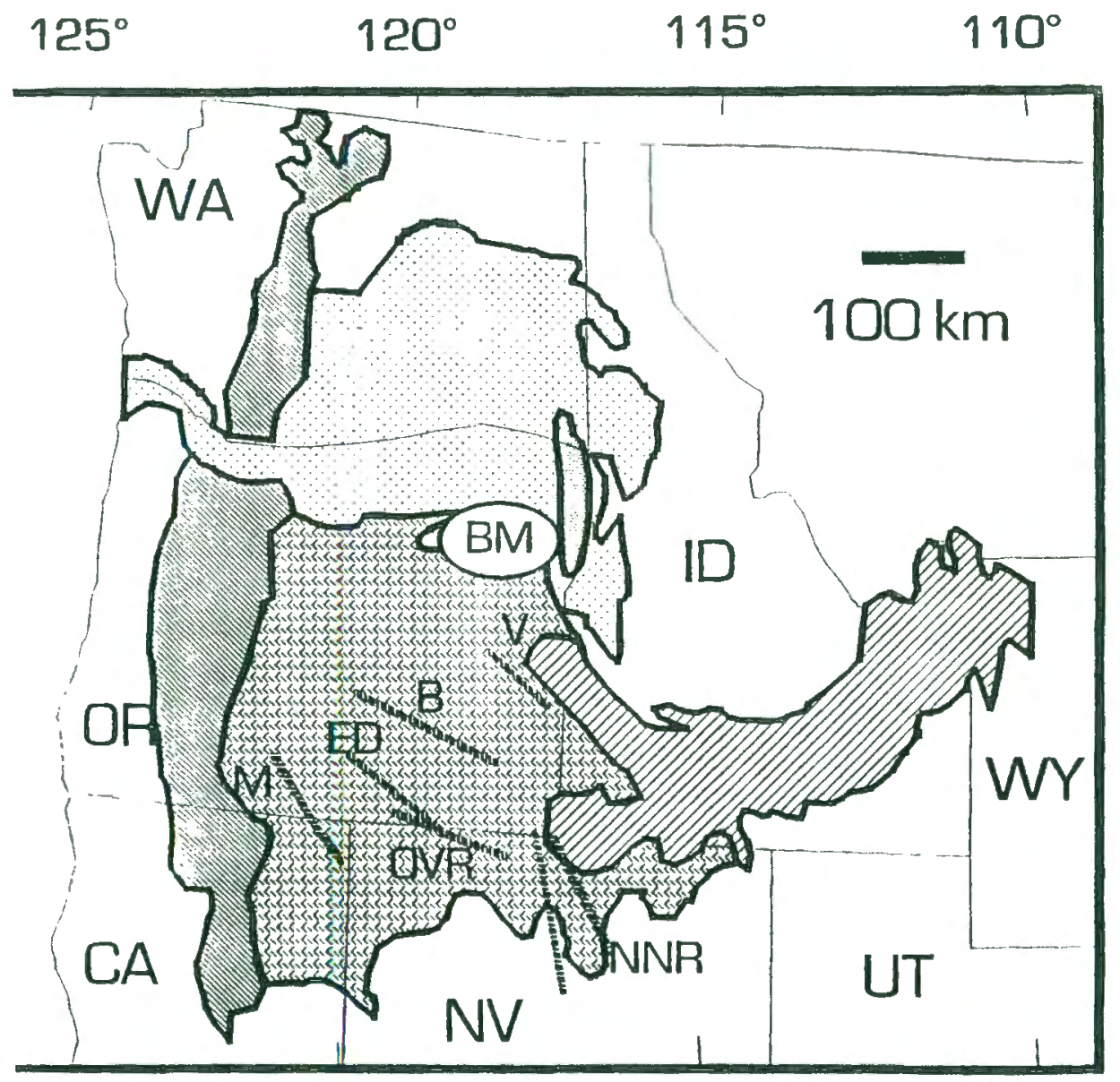

\section{CASCADES}

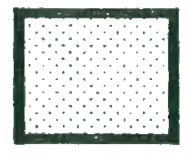

COLUMBIA PLATEAU

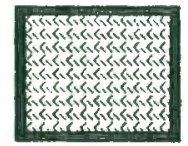

OREGON PLATEAU

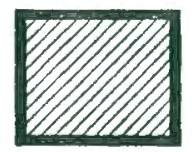

SNAKE RIVER PLAIN

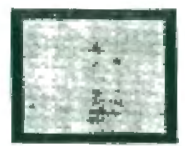

CHIEF JOSEPH DIKE SWARM

(BM) BLUE MOUNTAINS

$V=$ Vale fault zone, $B=$ Brothers fault zone. $M=$ McLaughlin fault zone, ED = Eugene-Denio fault zone, OVR = Orevada Rift, NNR $=$ Northern Nevada Rift,

Figure 3. Physiographic setting of the study area (Modified from Hart and Carlson, 1987). 
basement in the northern Great Basin, delineates the southern edge (Rytuba and McKee, 1984). The eastern margin of the plateau is defined by the Oregon-Nevada lineament (Zoback and Thompson, 1978). The Northern Nevada rift and feeder dikes of the Steens Basalt occur at the southern end of the Oregon-Nevada lineament and the western Snake River Plain graben and main dike swarms of the Columbia River Basalt at the northern end (Zoback and Thompson, 1978). Clues to the nature of the earliest extension are derived from studies of proposed Miocene rift systems. The earliest extension in the Oregon Plateau took place between 21 and 24 Ma along the NW-striking Orevada rift (Rytuba and Conrad, 1981). The Oregon-Nevada lineament was active between 17 and $14 \mathrm{Ma}$, during which time the main portion of the Steens Mountain basalts and Columbia River basalts were erupted. Both rift systems indicate a general NE-SW, early to mid-Miocene extension direction (e.g., Christiansen and McKee, 1978; Zoback and Thompson, 1978; Rytuba and Conrad, 1981). Eaton (1982) and Hart and Carlson (1987) postulate that a change in stress orientation from NE-SW to $E-W$ extension occurred at $17 \mathrm{Ma}$. Barrash and Venkatakrishnan (1982) postulate that extensional deformation in the Great Basin area was influenced by transform motion along the western margin of North America that developed by northward migration of the Mendocino triple junction from 14 to $10 \mathrm{Ma}$. Around $10 \mathrm{Ma}$, the Pacific plate changed its spreading 
direction from E-W to NW-SE relative to the Juan de Fuca plate (Barrash and Venkatakrishnan, 1982).

The geology, stratigraphy and structure of Steens Mountain-Pueblo Mountains and Alvord basin have been described by Fuller (1931), Williams and Compton (1953), Wilkerson (1958), Walker and Repenning (1965), Gunn and Watkins (1970), Cleary (1976), Hook (1981), Minor et al. (1987a, 1987b, 1987c), Hemphill-Haley (1987), Hemphill-Haley et al. (1989) and Langer (1991).

\section{STRAT I GRAPHY}

The mountain ranges surrounding the Alvord basin are dominated by voluminous Tertiary volcanic rocks and minor sedimentary rocks. Table 1 presents the stratigraphy of the Alvord basin and surrounding mountain ranges. Figure 4 is a conceptual representation of the stratigraphy of the steens Mountain fault block and the Alvord basin. The dominant lithology, Steens Basalt, covers an area of $75,000 \mathrm{~km}^{2}$ and has a volume of 30,000-35,000 $\mathrm{km}^{3}$ (Mankinen et al., 1987). The flows are time equivalent to the early Columbia River Basalt, the Owyhee Basalt and the Snake River Basalt.

The Alvord Creek Formation, Pike Creek Formation and Steens Mountain Volcanics (Andesite Series) are stratigraphically below the steens Basalt. These units have no obvious equivalents in the surrounding area. They include rhyolite, dacite, and andesite flows and tuffs. 
MABLE I

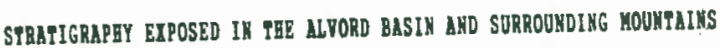

Unit

Paller (1931), villiase and Compton (1953), and Gunn and Hatkins (1970)
Walker and Repenning (1965), Hinor et al (1987a, b and $c$ ), and Langer (1981), present stndy

Mllnviu
Allaviua -.......... pnconfornity

Rhyolite asb-ilow tuffs and breccias

Steens Basalt

Steens Basalt

Steens Hountain Andesite Series

Steens Yonntain

Volcanics

Pile Creek
Volcanic Series
Alvord Creek Beds

Description

Valley fill consisting of sand, gravel and bonlder deposits, sand, silt and lacustrine sedinents. Fotal thichness estizated to be 0.5 to 1 kn in the riddle of the basin. Pleistocene to Bolocene

Partially relded ash-flow tuffs and breccias overlie SMB betreen Steens Monntain and Pueblo Monntains. 100 to 150 in thickness.

Exposed locally.

Thin, irregularly bedded flows of porpbyritic to aphyric olivine tboleiite to bigh alunina basalt. Thickness exceeds 1000 on the ligh Steens. Middle Hiocene (18 to $11 \mathrm{ka}$ ).

Thick and locally extensive olivine and augite basalt and anygdaloidal andesite rich in reolites orerlain by thin andesite and basalt flors and clastic naterial of variable thickness. Thickness exceeds $700 \_$in Steens Mountain and Pueblo Hountaius. Farly to aiddle tiocene (23 to $19.5 \mathrm{Ma}$ ).

Mhyolitic asb-flow tuffs. Total thichness is 300 to 500 m. Barly Liocene.

Light colored, fossiliterous tuffs and sedinents, claystone, opaline chert, and couglonerate in thin and thick beds.

Thickness ranges fron 50 to 200 a

Minor afic flows near base of section. sariy Miocene. 


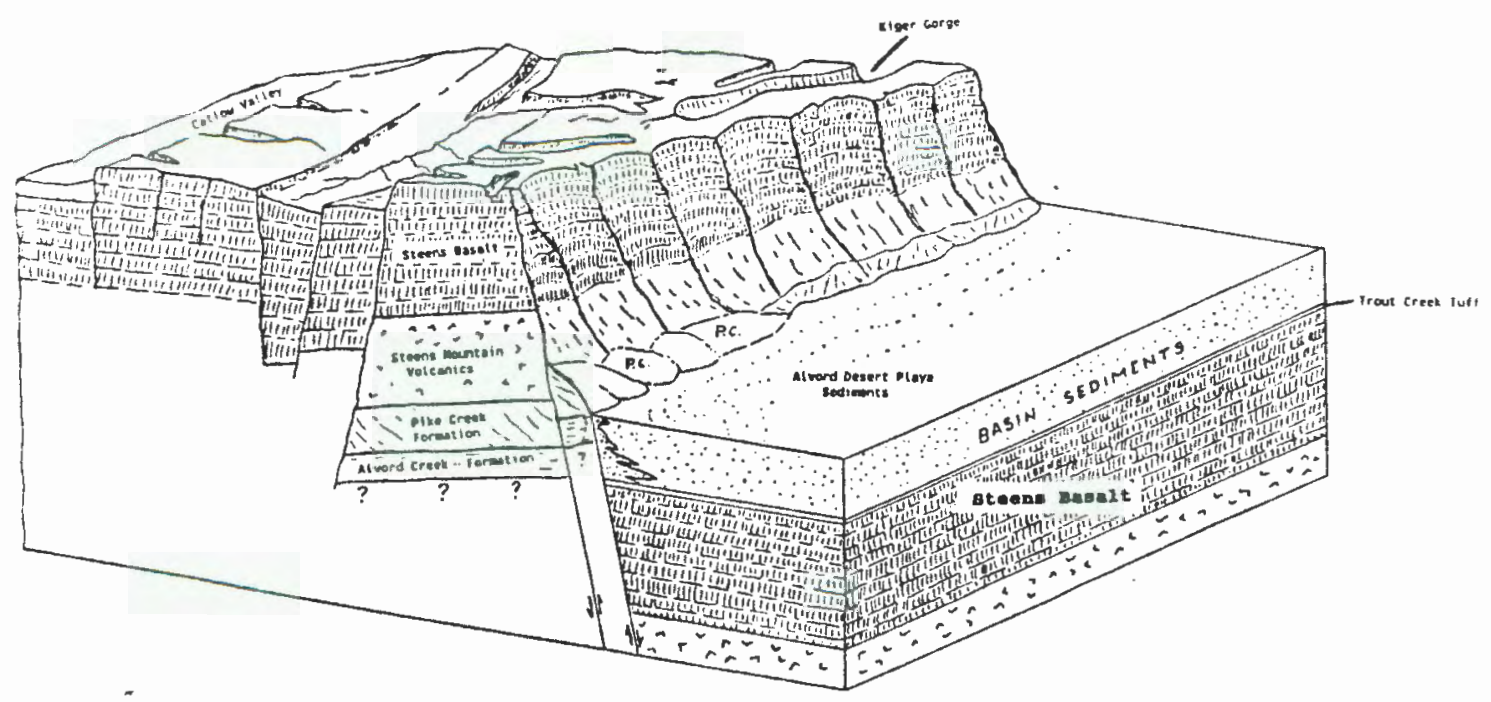

Fiqure 4. Generalized Stratigraphy of Steens Mountain and Alvord basin (modified from orr et a.. 1992) 
Major angular unconformities exist between the Pike Creek Formation and Steens Mountain Volcanics and between Steens Mountain Volcanics and Steens Basalt (Minor et al., 1987a, $1987 b$ and 1987c).

\section{Pre-Tertiary Rocks}

Pre-Tertiary crystalline rocks are exposed in the southwestern part of the Alvord basin along the crest of the Pueblo Mountains from just west of Tumtum Lake to the Nevada state line (Figure 1). The section exposed in the eastbounding fault scarp consists of Paleozoic and Mesozoic metamorphic and granitic intrusive rocks, overlain by a series of Tertiary volcanic rocks. Mesozoic intrusive rocks include granodiorite and quartz diorite, partly gneissic. Moderate to steeply dipping Permian or Triassic metasedimentary and metavolcanic rocks include an assemblage of quartzites, graywacke, greenstone, sericite schist, quartz-muscovite schist, muscovite-chlorite-actinolite schist, argillite and minor marble. The pre-Tertiary rocks do not crop out near Steens Mountain, but are inferred by Williams and Compton (1953) to underlie the extensive Tertiary volcanic sequence exposed in this scarp.

\section{Tertiary Rocks}

Tertiary volcanic and volcaniclastic deposits are the rock units that compose steens Mountain, Trout Creek Mountains, Sheepshead Mountains, and part of the Pueblo 
Mountains. The relative age and stratigraphic position of units is discussed relative to the middle Miocene steens Basalt.

Pre-Steens Basalt Section. Fuller (1931) was the first to describe the Tertiary volcanic rocks in the eastern escarpment of Steens Mountain. The lowest stratigraphic units are stratified silicic tuffs called the Alvord Creek Beds (Table 1), which have been intruded by a basaltic sill and subsequently arched by a rhyolite laccolith. The base of this unit is covered, and the maximum exposed thickness is about $275 \mathrm{~m}$ in the Alvord Creek Canyon (Figure 1) (Libbey, 1960). The Alvord Creek Beds are overlain by $500 \mathrm{~m}$ of stratified tuffs and silicic flows of the Pike Creek Volcanic Series.

The Pike Creek Volcanic Series is overlain by andesite flows called the Steens Mountain Andesite Series (Table 1) and approximately $1,000 \mathrm{~m}$ of basaltic flows of the steens Basalt. The angular unconformity between Steens Basalt and the Steens Mountain Andesite Series is typically greater than $15^{\circ}$, and as much as $30^{\circ}$ (Fuller, 1931). Basaltic dikes, which strike approximately $N-S$, cut through the steens Basalt and through the underlying tuffs and lavas. Minor et al. (1987a, 1987b, 1987c) remapped the area covered by Fuller (1931). They established a more detailed stratigraphy on 1:24,000 scale maps. The Alvord Creek Beds were renamed the Alvord Creek Formation; the Pike Creek 
Volcanic Series is now the Pike Creek Formation, and the Steens Mountain Andesite Series is the Steens Mountain Volcanics (Minor et al., 1987a, 1987b, 1987c). This nomenclature will be used in this study.

Steens Basalt. K-Ar dates from Watkins and Baksi (1974), Hart and Mertzman (1982) and Hart and Carlson (1985) indicate that the main volume of steens Basalt was extruded between 14.5 and $17 \mathrm{Ma}$, and the total age range is $11 \mathrm{Ma}$ to $18 \mathrm{Ma}$. Watkins $(1965,1969)$ infers that no significant time gap exists between single lava flows, due to the absence of interflow sediments and the presence of welded contacts between some lava flows. Paleomagnetic data indicate a change in the geomagnetic field from reversed to normal polarity in middle Miocene time (15 Ma) (Watkins 1965, 1969). Goldstein et al. (1969) confirmed these results. Mankinen et al. (1987) note that the field reversal occurred in two stages and is entirely recorded in steens Basalt exposed on the High Steens; this observation makes the High steens a reference section for magnetostratigraphy.

Post-Steens Basalt. Welded ash flow tuffs overlie Steens Basalt (Walker and Repenning, 1965; Rytuba and McKee, 1984). Ash flow tuffs, possibly erupted from the McDermitt volcanic field, outcrop between the Steens and Pueblo Mountains (Langer, 1991) and indicate that block faulting occurred after 9.3 Ma (Rytuba and McKee, 1984). However, Langer (1991) mapped rhyolitic flow breccias and partly 
welded ash-flow tuffs in the vicinity of Red Mourtain, a small hill located on the Steens Mountain fault block approximately $8 \mathrm{~km}$ northwest of Fields. She notes that flows at Red Mountain were erupted from a central crater with preserved ring breccia. Mapping by Langer (1991) indicates eruption of rhyolitic flow breccia and ash-flow tuffs from local vents as opposed to the McDermitt volcanic field to the south.

\section{Quaternary Deposits}

The Alvord basin is filled with alluvial and lacustrine deposits. Lake shorelines and lacustrine deposits at the surface attest to the presence of at least two late Pleistocene paleolakes in the valley that were up to $100 \mathrm{~m}$ deep (Hemphill-Haley, 1987). Hemphill-Haley (1987) and Hemphill-Haley et al. (1989) have mapped three separate late Quaternary-aged lacustrine and fluvial sequences along the western side of the Alvord basin. The following summary is modified from Hemphill-Haley (1987).

The older lacustrine deposits are exposed south of Indian Creek along the lower flank of Steens Mountain between $1,310 \mathrm{~m}$ and $1,280 \mathrm{~m}$. They consist of generally well developed beds of silty sand and medium- to coarse-grained sand and gravel. Individual beds are nearly horizontal, up to $4 \mathrm{~cm}$ thick, and commonly exhibit cross-bedding. Intermediate-aged lacustrine deposits are exposed south of Tuffy Creek below a prominent shoreline cut into the 
older lacustrine deposits at about $1,310 \mathrm{~m}$. They consist of medium to light brownish-gray silty to medium and coarsegrained sand and gravel, grading to fine sand, silt and clay away from the range front. Bedding is well-developed and beds dip up to $4^{\circ}$; beds thin toward the interior of the basin ranging from $10 \mathrm{~cm}$ to less than $1 \mathrm{~cm}$ thick. Evidence that the intermediate-aged paleolake was a separate lake from the earlier, older lake (instead of a prolonged recession of the older lake), includes relatively youthful, sharp-crested gravel bars at a maximum elevation of $1,378 \mathrm{~m}$ and a well-developed, youthful shoreline at that elevation that cuts the older, more eroded barrier bar deposits. Recent, unconsolidated sediments consisting of lightgray coarse sand and gravel have been deposited along the beaches associated with "present" lake levels of Alvord Lake. Sediments from the center of the lake are light-brown to light-gray, fine silt and sand.

Sand- and gravel-sized material varies in lithology depending on location in the Alvord basin. Thin section analysis of late Pliocene (Ross, 1942) to early Pleistocene (Williams and Compton, 1953) silicified sandstones south of Borax Lake (Figure 1) indicate volcanic, plutonic and metamorphic lithic clasts (Cummings and St. John, 1993). However, thin section analysis of silicified sandstones in the Mickey Springs area indicate variously textured basalt clasts (Cummings and St. John, 1993). 
STRUCTURE

Dips of volcanic rocks vary from $5^{\circ}$ to $30^{\circ}$ to the west. Generally, the Steens Mountain block dips to the west at $5^{\circ}$ or less. Most of the faults that bound the valley on the west strike approximately north-south. The east-facing scarp and frontal fault generally trend $\mathrm{N} 5^{\circ} \mathrm{E}$ but have sections where the trend approaches $N 25^{\circ} \mathrm{E}$. Another set of faults strike $\mathrm{N} 30^{\circ} \mathrm{W}$ to $\mathrm{N} 60^{\circ} \mathrm{W}$ with maximum displacements of only a few hundred meters. Cleary (1976) noted evidence of recent faulting $11.8 \mathrm{~km}$ due east of Alvord Hot Springs. He observed a series of north-south trending fractures in playa sediments and mounds of dirt and deformed greasewood on opposite sides of the fractures. An attempt to confirm these observations during the summer of 1992 was not successful.

The Steens Fault Zone (SFZ) (Hemphill-Haley, 1987) is a system of normal faults located along the base of the Steens Mountain escarpment. These faults are expressed at the surface as predominately east-facing scarps that displace late Quaternary lacustrine and alluvial deposits, lake strand lines and Tertiary volcanic rocks.

Hemphill-Haley et al. (1989) evaluated a segment of the SFZ known as the Alvord fault; it extends from Big Alvord Creek south for a distance of $27 \mathrm{~km}$ along the base of Steens Mountain, and then crosses the Alvord Desert and dies out in the playa. The northwestern $16 \mathrm{~km}$ of the fault is generally 
a single trace, while the southern portion branches into several splays that bound Serrano Point and Alvord Point. The Alvord fault trends $N 18^{\circ} \mathrm{W}$ to $N 12^{\circ} \mathrm{E}$ and is a high-angle normal fault that dips $72^{\circ}$ to the east. This segment appears to have ruptured less than a few thousand years before present and at earlier periods during the Holocene.

A number of geophysical studies have been performed in the Alvord basin to define the large-scale structure of the valley. Cleary (1976) conducted four east-west and two north-south gravity surveys (i.e. station spacing of 0.5 to $1.6 \mathrm{~km})$. Computer-generated structural models show that the average depth to basement ranges from 1.0 to $1.5 \mathrm{~km}$ in the western and southern portions of the Alvord Desert (Figure 1). In addition, one of the deepest portions of the valley is southeast of Alvord Desert and has a depth to basement between 1.5 and $2.5 \mathrm{~km}$ (Figure 1 ). Cleary (1976) notes that the Bouguer gravity in the valley reflects the general north-south structural trend and that gravity increases sharply near the valley sides where the valley-bounding normal faults are located.

Griscom and Conradi (1975) performed seven detailed gravity and magnetic surveys (i.e. station spacing of 100$200 \mathrm{~m}$ ) across areas of possible geothermal interest in the Alvord basin. A steep east-sloping gravity gradient is evident in profiles on the west side of the basin near Alvord Hot Springs. Griscom and Conradi (1975) infer that a 
large, thick mass of low-density valley fill located in the center of the Alvord basin causes this gradient. In addition, they note that gravity data imply maximum sediment thicknesses of $0.4 \mathrm{~km}$ under Alvord Lake and $0.6 \mathrm{~km}$ under Alvord Desert. Magnetic surveys suggest a maximum depth range to magnetic material, presumably volcanic basement, from 400 to $500 \mathrm{~m}$ in the middle of the Alvord Desert (Griscom and Conradi, 1975). They infer that the Alvord Desert is strongly asymmetric, with the deepest part being on the west side near the Steens Mountain fault block. The discrepancy in maximum sediment thicknesses among researchers may be due to the station-spacing used in the gravity surveys; a closer station-spacing yields better resolution of shallow features. A steep linear north-south gravity gradient is evident on the west side of Alvord Desert. Griscom and Conradi (1975) note that a major fault is located at the steepest part of the gradient, coincident with Alvord Hot Springs. 
REGIONAL HEAT FLOW

The northern Basin and Range province is characterized by abnormally high geothermal gradients and anomalous thinning of the Earth's crust. For example, hot springs and historic earthquakes in the Alvord basin (e.g., 1900-1981 of $\mathrm{M}_{\mathrm{L}}<5$, Eddington et al., 1987) indicate ongoing activity. Seismic refraction data indicate a crustal thickness of 37 km in central Oregon, while a crustal thickness of $32 \mathrm{~km}$ is indicated for northwestern Nevada (Catching, 1990). Eddington et al. (1987) calculated momentary horizontal deformation at the Oregon-Nevada border to be $0.2 \mathrm{~mm} / \mathrm{a}$ for a WNW-ESE trending extension, based on 71 earthquakes.

Sass et al. (1981) divided the northern Basin and Range province into three heat flow regimes: A region of heat flow typical of the average heat flow of the province (e.g. surface heat flow values of about $85 \pm 10 \mathrm{mWm}^{-2}$ ); a region of above average heat flow (surface heat flow values of $100^{*}$ $\mathrm{mWm}^{-2}$ ) which is designated as the Battle Mountain Heat Flow High, and a region of below average heat flow values which is called the Eureka Heat Flow Low (surface heat flow values of less than $\left.60 \mathrm{mWm}^{-2}\right)($ Figure 5$)$. The regional heat flow in the Alvord basin and northern Nevada is 60-100 $\mathrm{mWm}^{-2}$ and the regional geothermal gradient is $40-60^{\circ} \mathrm{C} / \mathrm{km}$ based on sparse data (Blackwell et al., 1978). 


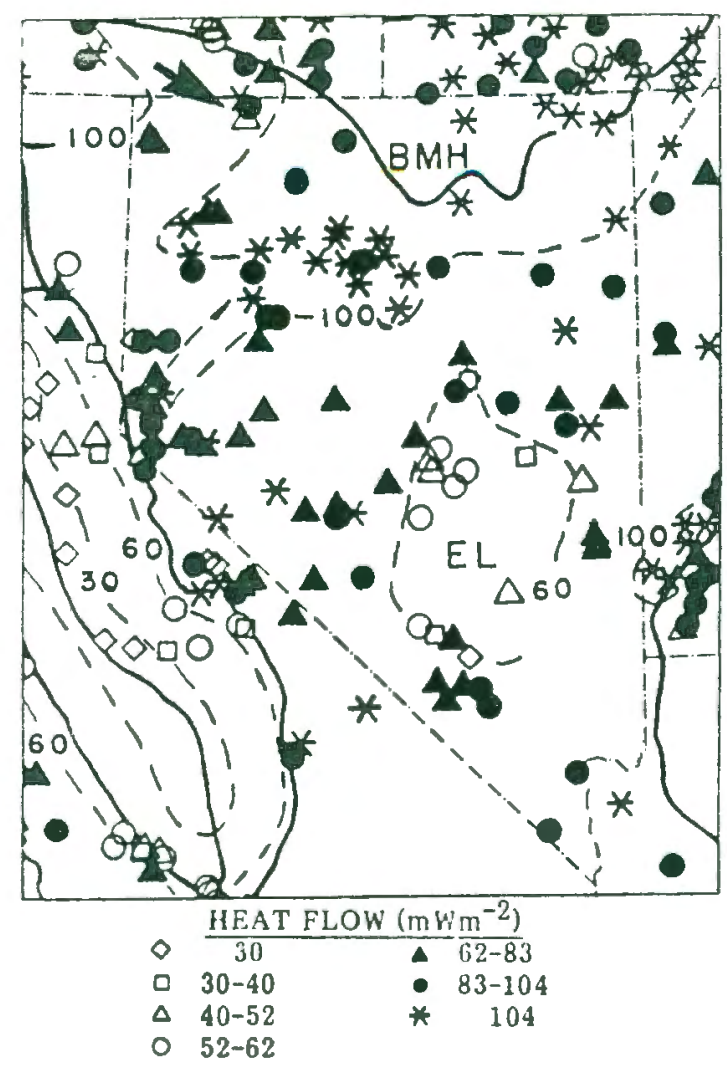

Figure 5. Heat flow in Nevada and surrounding areas (from Blackwel1, 1983).

Brown and Peterson (1980) conducted temperature gradient and heat flow studies in the Alvord basin. The following downhole heat flow measurements were obtained in the Alvord basin: 268 and $134 \mathrm{mWm}^{-2}$ near Mickey Springs, $66.9 \mathrm{mWm}^{-2}$ near Alvord Hot Springs, $52 \mathrm{mWm}^{-2}$ along the southeast side of the Alvord Desert, and 66-126 $\mathrm{mWm}^{-2} 10$ in the valley approximately 10 to $20 \mathrm{~km}$ southwest of the Whitehorse Ranch (Brown and Peterson, 1980). The following thermal gradient estimates were computed for the above areas: 146.2 and $289.8^{\circ} \mathrm{C} / \mathrm{km}$ near Mickey Springs, $78.6{ }^{\circ} \mathrm{C} / \mathrm{km}$ 
near Alvord Hot Springs, $58.5{ }^{\circ} \mathrm{C} / \mathrm{km}$ along the southeast side of the Alvord Desert and $61-130.6{ }^{\circ} \mathrm{C} / \mathrm{km}$ in the valley southwest of the Whitehorse Ranch. Blackwell et al. (1986) modelled "shallow" (61-76 m) and "deep" (unspecified depth) geothermal gradients in the vicinity of Borax Lake. They noted that an area of over $20 \mathrm{~km}^{2}$ has a geothermal gradient of at least $100^{\circ} \mathrm{C} / \mathrm{km}$ and an area of at least $2 \mathrm{~km}^{2}$ has gradient values greater than $340^{\circ} \mathrm{C} / \mathrm{km}$. Typical background gradients in the valley sediments range from 35 to $60^{\circ} \mathrm{C} / \mathrm{km}$ in the 3-4 km area surrounding Borax Lake. The high heat flow values and thermal gradients occur as a result of circulation of hot water that is believed to rise along nearby faults and spread laterally through valley fill deposits at shallow (less than $100 \mathrm{~m}$ ) depths.

The regional heat flow of the Alvord basin is estimated using the method of Swanberg (1979) and Swanberg and Alexander (1979), in which regional heat flow is correlated with the silica content of cool groundwater. Heat flow, q, is calculated in milliwatts per square meter $\left(\mathrm{mW} / \mathrm{m}^{2}\right)$ as follows:

$$
\mathbf{q}=\underline{\mathbf{T}}_{\mathrm{qt}:} \frac{-\mathbf{b}}{\mathrm{m}}
$$

where $b$ and $m$ are empirical constants $\left(13.2^{\circ} \mathrm{C}\right.$ and $0.67^{\circ} \mathrm{C}$ $\mathrm{m}^{2} / \mathrm{mw}$, respectively), where

$$
T_{q t z}=\frac{1309}{5.19-\log _{10}\left[\mathrm{SiO}_{2}\right]}-273.15
$$

and where silica concentration is in milligrams per liter 
$(\mathrm{mg} / 1)$.

Based on silica concentrations of 8 cold groundwater samples (Figure 1 and Table 2 ), the calculated heat flow values range from 83 to $185 \mathrm{mWm}^{-2}$ for the Alvord basin. Samples collected at sites believed to tap zones of thermal water mixed with local ground water have calculated heat flow values between 121 and $185 \mathrm{mWm}^{-2}$. Values for these areas are in general agreement with downhole measurements made by Brown and Peterson (1980) and Blackwell et al. (1986). High values (e.g. values obtained for springs near Mickey Springs) are in excess of previously estimated regional values.

It must be noted that the number of data points is small and that the constants, $b$ and $m$, were derived from mathematical analysis of thousands of water samples from the United States. None the less, the range of values is reasonable for the northern Basin and Range Province.

It is well-known that the Basin and Range province has high heat flow. Heat flow values for the Basin and Range Province average $85 \pm 10 \mathrm{mWm}^{-2}$ (Blackwel1, 1983). High heat flow values in the Alvord basin do not appear to be the result of shallow heat sources such as a shallow magmatic intrusion or young silicic volcanic rocks. Geothermal activity in the Alvord basin, like other geothermal systems in the Basin and Range Province, appears to be related to an active extensional tectonic setting rather than magmatic 
TABLE II

DETERMINATION OF HEAT FLOW FOR THE ALVORD BASIN

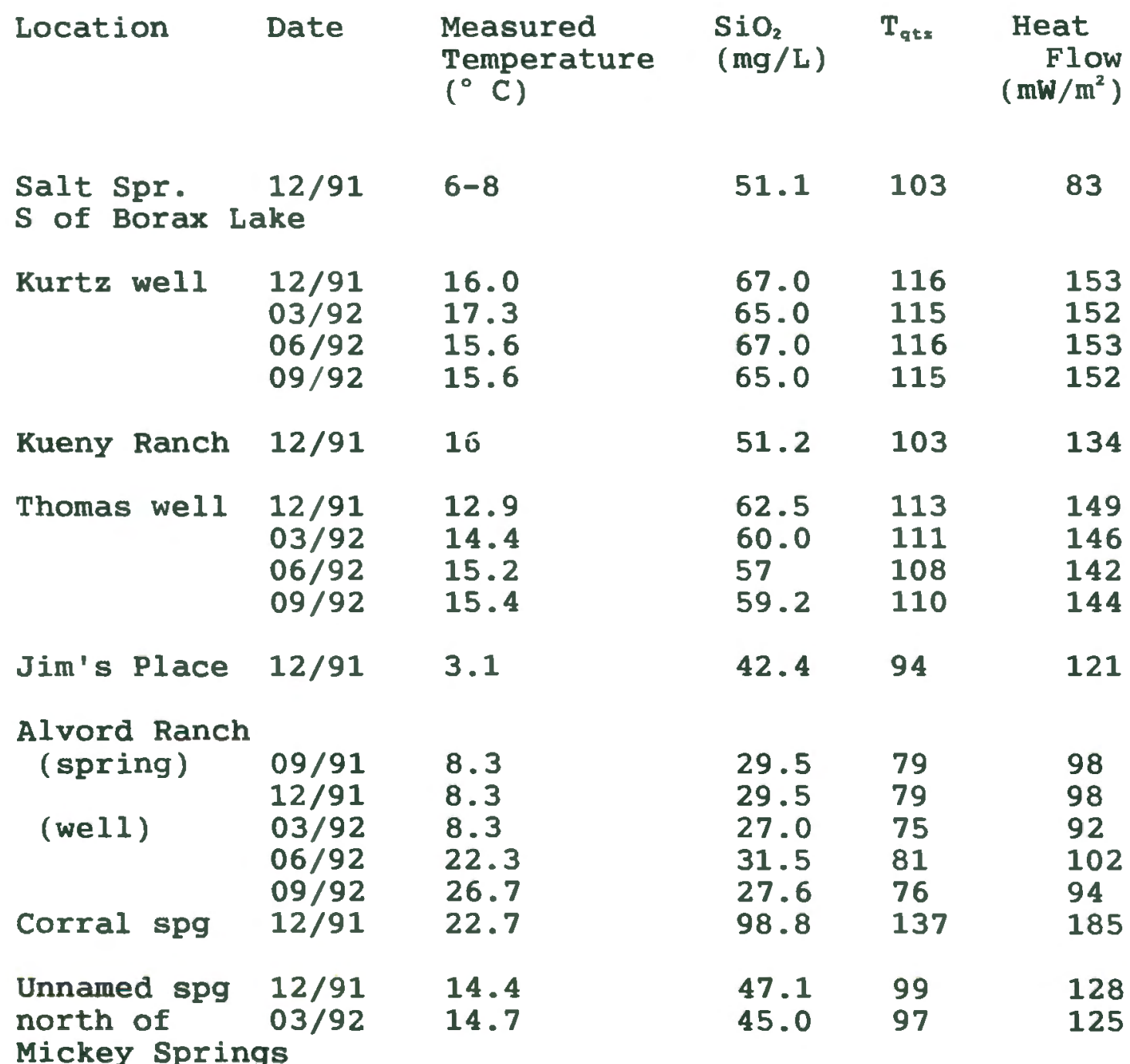


intrusions or recent volcanic activity. 
REGIONAL HYDROLOGIC SETTING

\section{CLIMATE}

Climate in the Alvord basin is typified by low rainfall, warm summers, and cold winters with large diurnal temperature fluctuations. The Alvord basin is located in the rain shadow of the Steens Mountain-Pueblo Mountains fault block; much of the precipitation brought into the region by westerly winds is intercepted by the fault block and fails to reach the Alvord basin. Mean annual temperatures and precipitation measurements are furnished by Everett Lofgren, Hines District, Bureau of Land Management. Mean annual temperatures range from $9.0^{\circ} \mathrm{C}$ at $\mathrm{P}$ Ranch at the foot of the western slope of Steens Mountain to $10.9^{\circ} \mathrm{C}$ at the Whitehorse Ranch in the Pueblo Valley. Average annual precipitation on the basin floor at the Whitehorse Ranch, northeast of Fields, and at Denio, Nevada for the period of 1941 to present is $18.6 \mathrm{~cm}$ and $20.1 \mathrm{~cm}$, respectively. Average annual precipitation at $1,830 \mathrm{~m}$ on the eastern slope of Steens Mountain at Western Brothers Mine for the period 1941 to present is about $43.1 \mathrm{~cm}$. 


\section{HYDROLOGY}

\section{Ground Water Flow}

Mifflan $(1968,1988)$ has discussed the hydrology of the Basin and Range and Great Basin physiographic provinces. The dominant hydrologic regime in the Basin and Range province is a range-to-valley flow system. Aquifer heads are typically highest in the mountains and lowest in the valleys (Figure 6). This observation implies recharge in the mountains and discharge in the valleys.

The characteristics of ground water in the Alvord basin are known from data on wells and springs in the basin (Townley et al, 1980; State of Oregon Water Well Reports). Most of the wells in the Alvord basin penetrate alluvial or lacustrine deposits to depths of greater than $164 \mathrm{~m}$. Many of the wells near the valley walls penetrate basalt. Water levels at most places in the basin are within $10 \mathrm{~m}$ of the land surface.

Springs are widely scattered in the basin and the adjacent mountains. Most are gravity springs fed by precipitation in the Steens Mountain-Pueblo Mountains fault block. They issue from the surface of the eastern slope of the Steens Mountain-Pueblo Mountains fault block (e.g. spring above Jim's place; spring west of Alvord Ranch near Big Alvord Creek), at the base of alluvial fans or fault scarps (Thomas well and springs along western margin of Alvord Desert) and on or near the basin floor at some 


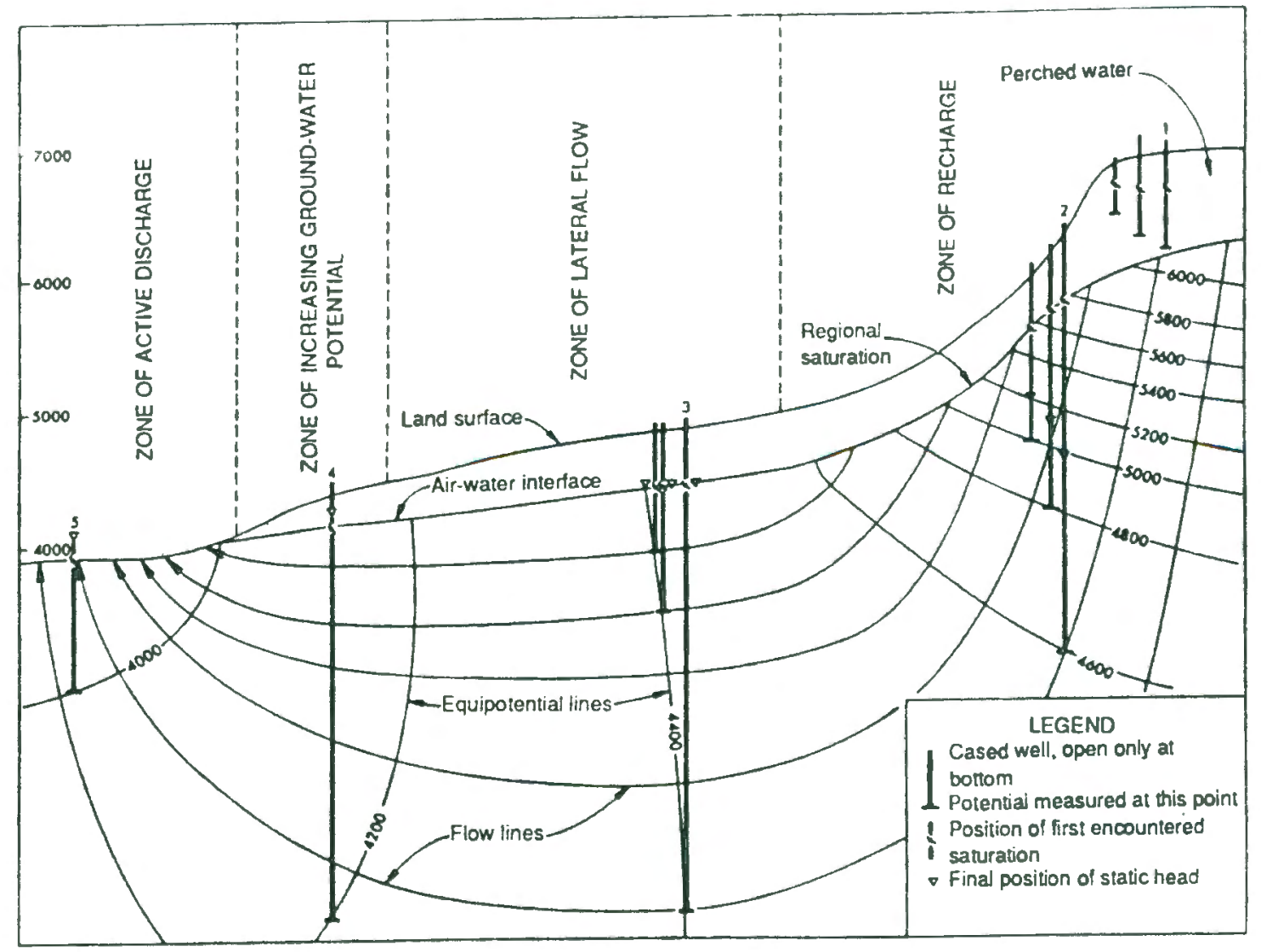

Fiqure 6. Idealized sketch of fluid potential relationships in Great Basin flow systems (from Mifflan, 1988). 
distance from the fault block (Kueny Ranch spring, McDade place spring)(Figure 1 ).

Movement of non-thermal water in the shallow subsurface in the Alvord basin cannot be fully described on the basis of available information. However, general movement patterns may be estimated from water use and areas of discharge.

Large quantities of ground water are withdrawn by numerous wells from sand and gravel and fractured basalt aquifers along the western margin of Alvord basin. Many wells produce several hundred liters of water per minute, and the water is used chiefly for irrigation (Townley et al., 1980). Ground water discharge from springs is common along the base of alluvial fans and fault scarps. The groundwater system is recharged by precipitation in the mountains and infiltration of streamflow through alluvial fans along the eastern flanks of the Steens Mountain-Pueblo Mountains fault block. Each spring, snowmelt runoff from upland streams from Steens Mountain and the Pueblo Mountains recharges the shallow section of Alvord basin fill (Townley et al., 1980). In addition, Piper et al. (1939) note that upward movement of groundwater from the underlying consolidated rocks also provides small quantities of recharge to valley fill deposits. 
Deep Thermal Water Flow

In general, the boundaries between the valleys and the mountains in the Basin-and-Range Province are defined by numerous parallel or en echelon normal faults. The Alvord basin is no exception (Hemphill-Haley et al., 1989). Fracturing and faulting associated with multiple seismic events and ongoing tectonic activity have resulted in enhanced vertical conductivity that may allow localized deep movement of water and recharge of Alvord basin thermal areas by cold meteoric water from the Steens Mountain-Pueblo Mountains fault block.

\section{Surface Hydrology}

The Alvord basin is essentially flat with interior drainage toward two ephemeral lakes, Tumtum at the south end and Alvord in the central portion (Figure 1). These lakes have an areal extent and depth which vary with seasonal precipitation and streamflow. The largest stream in the Alvord basin is Trout Creek, which flows north through Pueblo Valley into Alvord Lake in northern Pueblo Valley. In addition, numerous small streams flow off the east flank of Steens Mountain and the Pueblo Mountains into Alvord basin. A larger playa, the Alvord Desert, covers about 250 $\mathrm{km}^{2}$ in the north-central part of the valley. These ephemeral lakes and playas serve as terminal sinks for surface water in the Alvord basin. Discharge from closed basins, such as the Alvord, consists of direct evaporation 
from a playa or lake surface and transpiration by phreatophytes, plants which line the floodplains of perennial streams and surround playas, and mark extensive areas where the water table is less than $15 \mathrm{~m}$ below the surface (Mifflan, 1988). 


\section{SAMPLING AND ANALYSIS}

\section{WATER SAMPLES}

Hot spring samples, cold springs and well water were collected as outlined by Presser and Barnes (1974), Thompson (1975), Wood (1976) and Giggenbach and Goguel (1989a).

Temperature and $\mathrm{pH}$ were measured in the field using a VWR Scientific Cat. No. 34100-674 pH-MV-Temperature Meter. Measurement of $\mathrm{pH}$ was made after standardization using two buffers (with nominal pH values of 4,7 , and 10) that spanned the sample value. The temperature measurements were taken as close to the source as possible (e.g., at the top of the casing of flowing wells, in the thermal spring vent with the greatest amount of flow).

Samples for cation and anion analysis were collected and filtered through 0.45 micrometer pore-size filters prior to placing in acid-washed polyethylene bottles. Reagent grade hydrochloric acid was added to samples for cation analysis to preserve dissolved metals and acidify the sample to a $\mathrm{pH}$ below 2 . Samples collected for anion analysis were not acidified and were completely filled to enhance preservation of carbonate species. Samples collected for dissolved silica were diluted with deionized water where analyses indicated silica concentrations greater than 50 
mg/L. The dilution prevented polymerization of silica prior to analysis and is a commonly employed procedure for collection of geothermal fluids. Samples collected for stable-isotope analysis (H, O) were placed in $250 \mathrm{ml}$ polyethylene bottles with polyseal caps. The bottles were completely filled and sealed to prevent the loss of water vapor.

Cations and silica were analyzed using inductively coupled plasma atomic emission spectroscopy (EPA Method 6010). Anions were analyzed using ion chromatography (EPA Method 300.6). Samples were analyzed at the Inorganic Chemistry Laboratory, Keystone/NEA, Tigard, Oregon.

Stable isotope ratio analyses for oxygen and hydrogen were determined by standard methods at the Geochron Division, Krueger Enterprises, Inc., Cambridge, Massachusetts. Carolyn Colonero, Geochron Laboratories Division, Krueger Enterprises furnished analytical procedures. Hydrogen is generated from water samples by reacting about 5 microliters of sample with uranium metal at $800^{\circ} \mathrm{C}$. Samples of water oxygen are prepared by equilibrating $2 \mathrm{ml}$ of the water sample with 5 ccSTP of pure carbon dioxide gas in a sealed tube at $25^{\circ} \mathrm{C}$; the equilibrated $\mathrm{CO}_{2}$ gas is then withdrawn and cryogenically purified. The gas analyses are performed on specially designed dual-inlet, double or triple collecting isotope ratio mass spectrometers, such as a VG Isogas 602D Siamese 
double collecting instrument and a VG Isogas 903 triple collecting instrument. Isotopic data for water is expressed relative to standard mean ocean water (SMOW).

Tritium concentrations were determined at the Tritium Laboratory, University of Miami. The analysis procedure consists of distillation, enrichment of tritium by electrolysis, and measurement by gas counting (Ostlund and Dorsey, 1975).

Sulfate was precipitated with $\mathrm{BaCl}_{2}$ for determination of oxygen and sulfur isotopes. Oxygen isotope ratios in sulfate were determined by $\mathrm{Dr}$. Ben D. Holt at Argonne National Laboratory using the graphite reduction method of Holt (1977).

Sr-isotope ratios of thermal fluids were measured on a VG-54R mass spectrometer by the Analytical Chemistry Laboratory, Argonne National Laboratory. In the field, all samples were filtered with $0.45-\mu m$ membrane filters, stored in pre-washed polypropylene bottles and preserved with HCL to $\mathrm{pH} \leq 2$. In the laboratory, $100 \mathrm{ml}$ of water was first evaporated to dryness to concentrate the strontium prior to chemical separation.

\section{GAS SAMPLES}

Gas sampling was performed with the assistance of $\mathrm{Dr}$. Neil Sturchio at the springs north of Borax Lake, Alvord Hot Springs and Mickey Springs. Gas samples could not be 
collected at Borax Lake due to logistical problems. Gas samples were collected into a $4 \mathrm{~N} \mathrm{NaOH}$ solution in an evacuated $300 \mathrm{ml}$ flask equipped with a Rotaflo valve and analyzed by the method of Giggenbach and Goguel (1989a). Several parts of the procedure were modified as follows. Headspace gases were determined using a VG-3001 magnetic sector mass spectrometer (instead of by gas chromatography) and total $\mathrm{S}$ and $\mathrm{Cl}$ in the oxidized alkaline condensate were determined by ion chromatography (instead of gravimetrically and by titrations, respectively). Gas samples were analyzed at Argonne National Laboratory by Neil Sturchio.

Carbon isotope ratios for $\mathrm{CO}_{2}$ were determined in the following manner. An aliquot of the alkaline condensate was reacted with phosphoric acid in an evacuated flask. The $\mathrm{CO}_{2}$ thus produced was purified cryogenically and its volume measured by $\mathrm{Hg}$ manometer, then it was introduced into a precision isotope ratio mass spectrometer (VG Prism series II) for determination of its ${ }^{13} \mathrm{C}$ value relative to the PDB standard. Uncertainty of the procedure is \pm 0.1 per mil. Methane was combusted in a CuO furnace at $600^{\circ} \mathrm{C}$, and the resulting $\mathrm{CO}_{2}$ purified cryogenically for isotopic analysis.

All isotopic data for fluids, gases and rocks are expressed in $\delta$ notation, where

$$
\delta=\left(R_{\text {aapp } 1 .} / R_{\text {atandard }}-1\right) 1000 \text {, and }
$$

$\mathrm{R}=\mathrm{D} / \mathrm{H},{ }^{18} \mathrm{O} /{ }^{16} \mathrm{O}$ and ${ }^{13} \mathrm{C} /{ }^{12} \mathrm{C}$. Values are reported in $0 / 00$ relative to a standard. The standard for water (e.g., D/H 
and ${ }^{18} \mathrm{O} /{ }^{16} \mathrm{O}$ ratios) is standard mean ocean water (SMOW). The standard for ${ }^{13} \mathrm{C} /{ }^{12} \mathrm{C}$ ratios is Peedee Belemnite (PDB). 


\section{LITHOLOGY OF HOT SPRING AREAS}

Thermal features in the Alvord basin include three active hot spring areas shown in Figure 1. Mickey Springs and Alvord Hot Springs are located in the Alvord Valley while Borax Lake is in the Pueblo Valley. Mickey Springs is approximately $8 \mathrm{~km}$ northeast of the Alvord Desert. Sinter and silicified sandstone are found at this hot spring area. Alvord Hot Springs is located $1 \mathrm{~km}$ south of the Alvord Ranch. This thermal area consists of a NE-striking zone of seeps which occur at the base of the Steens Mountain fault block. Borax Lake and the hot springs to the north of Borax Lake are located $10 \mathrm{~km}$ northeast of Fields in the middle of the Pueblo Valley. The springs north of Borax Lake are aligned $\mathrm{N} 10^{\circ} \mathrm{E}$. Another hot spring is located $12 \mathrm{~km}$ east of the Pueblo Valley and south of Flagstaff Butte. Cummings and St. John (1993) present a detailed examination of the surface features, geology and geomorphic evolution of the three thermal areas. The following summary of surface features and geology is modified from Cummings and St. John (1993). 
BORAX LAKE

\section{Surface Features}

Borax Lake and hot springs extending to the north (Figure 7) are the surface expressions of the geothermal system located in the Pueblo Valley portion of the study area. Borax Lake, a warm water (greater than $22^{\circ} \mathrm{C}$ ) lake, has a surface area of $0.04 \mathrm{~km}^{2}$ and occurs at the crest of a low, shield-shaped mound that rises $8 \mathrm{~m}$ above the surrounding valley floor. The source of water for the lake consists of hot spring discharges entering the lake at a depth of $30 \mathrm{~m}$. At a topographically lower level, along the crest of a low rise, are hot springs that extend for $0.9 \mathrm{~km}$ north from the northwest corner of the lake. A warm artesian well occurs at the level of the surrounding playa $0.8 \mathrm{~km}$ northeast of Borax Lake.

\section{Lithology}

The geology in the vicinity of Borax Lake is presented in Figure 7. Cummings and St. John (1993) describe four lithologic units in the vicinity of Borax Lake, including 1) medium- to coarse-grained lithic sandstone to conglomeratic sandstone, 2) fine-grained sediments including diatomite, 3) silica sinter, and 4) unconsolidated sand.

Lithic sandstone and conglomeratic sandstone. Mediumto coarse-grained, cross-bedded, lithic-rich sandstone to conglomeratic sandstone is exposed southwest of Borax Lake. 


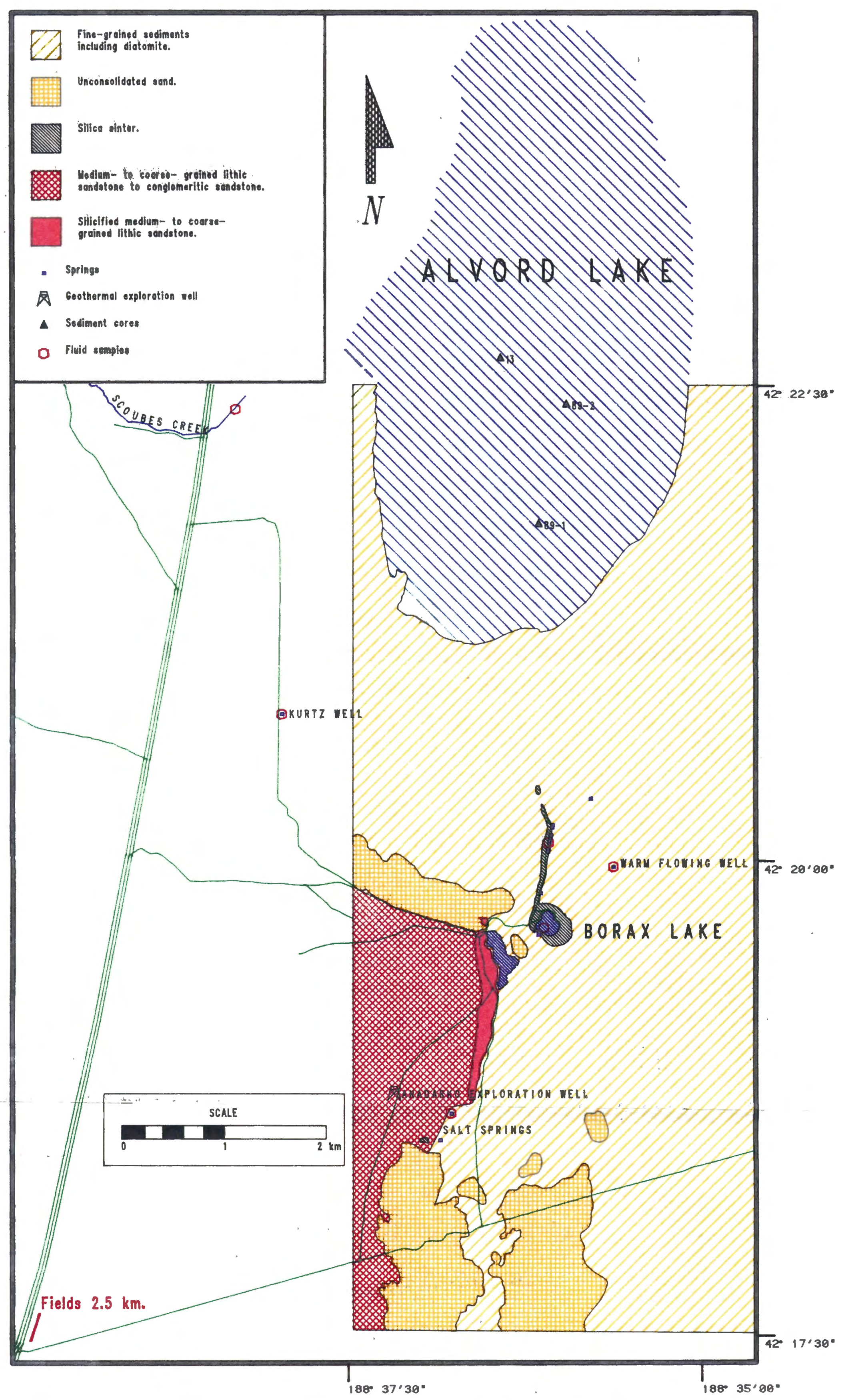

Figure 7. Geology of Borax Lake thermal area. 
Low outcrops extend from ledges up to $1 \mathrm{~m}$ high on the east for $0.6 \mathrm{~km}$ to the west where they disappear beneath surficial deposits. The outcrop area is coincident with areas of silica cementation. The lithic component includes volcanic, plutonic, and metamorphic rocks.

Fine-grained sediment. Fine-grained sedimentary deposits occur in all directions from Borax Lake (Figure 7 ). They consist of clay-rich deposits composed of approximately 808 clay. Minor quartz, feldspar, and magnetite are present along with trace amounts of what may be boracite, a magnesium borate, $\mathrm{Mg}_{6} \mathrm{Cl}_{2} \mathrm{~B}_{2} \mathrm{~B}_{8} \mathrm{O}_{25}$ (Zoltai and stout, 1984). Smectite, the most abundant clay mineral (81-848), occurs with kaolin $(5-6 q)$ and illite $(11-14 \%)$.

The stratigraphy of the mound at Borax Lake includes a layer of stiff, medium brown, clay-rich sediment at the top. The clay-rich layer unconformably overlies fine-grained, light gray sediment consisting of diatomite. The thickness of the diatomite layer is at least $5 \mathrm{~m}$ thick.

Silica sinter deposits. The distribution of silica sinter deposits is indicated in Figure 7. Sinter deposits occur around the edge and the bottom of Borax Lake, along the hot springs and small ponds north of Borax Lake, and near the salt springs south of Borax Lake. In places the sinter is overlain by fine-grained sediment that is up to 20-25 cm thick.

Sinter deposits associated with Borax Lake form a ledge 
that defines the boundary of the lake and underlies at least part of the lake bottom. The sinter ledge extends up to 37 m beyond the lake shore at the widest point. Small outflow channels are cut into the sinter and form part of the discharge system for the lake.

Two types of sinter deposits are present in and around Borax Lake. Cummings and st. John (1993) interpret the general lack of fossils, ridge patterns and mound structures on the bottom of the lake, particularly the eastern and northern lobes, and the lakeward dipping of fine-scale banding in sinter along the lake edge as evidence for sinter precipitated within and at the margins of a hot pool. Poolsinter deposits also occur around the main vent area where hot water enters the lake. In addition, the walls of this vent are armored, presumably by silica.

The morphology of the sinter that extends outward from the lake margin forming the flat top of the mound is consistent with sinter deposited from silica-bearing water flowing across a very low-relief surface. Evidence to support such an interpretation consists of relatively flatlying sheets of sinter, variable number of layers, abundant bulrush fossils, and thinning of layers away from the lake (Cumnings and St. John, 1993).

$\mathrm{X}$-ray diffraction analysis of Borax Lake sinter indicates nearly pure opal-A occurs with trace amounts of quartz, feldspar, and boracite (Cummings and St. John, 
1993). Sinter deposits also occur around the hot springs north of Borax Lake (Figure 7). Sinter deposits are locally exposed along the springs, but most of the sinter deposits are covered by a thin (less than $25 \mathrm{~cm}$ ) layer of finegrained sediment. The sinter deposits are up to $150 \mathrm{~m}$ wide near the northern end of the row of hot springs. The modern hot springs occur along a topographic break where sinter deposits west of the springs are up to $1 \mathrm{~m}$ higher than sinter deposits east of the topographic break. The modern springs are on the lower, eastern side of the break.

Unconsolidated alluvium and wind-blown deposits. Unconsolidated medium- to coarse-grained sands occur in dune-like features west and south of Borax Lake. The dunes are composed of lithic-rich sands and are up to $2 \mathrm{~m} \mathrm{high}$. Each dune is isolated from others by areas underlain by fine-grained sediments. Sage, bitter brush, and grasses grow on most of the dunes suggesting that they are largely inactive.

\section{MICKEY SPRINGS}

\section{Surface Features}

The geology of Mickey Springs is presented in Figure 8. The hot springs occur within a structural basin bounded by steep slopes cut into Steens Basalt on the west and east. The northeast-striking valley opens to the southwest into a broad depression that merges southward into the Alvord 




\section{EXPLANATION}

Unconsolidated collurium and allurium

Silica sinter

Unconsolidated bedded

silts and clays

Woll-rounded

unconsolidated conglomerate

Lithic sandstone to

conglomerate

Steens Basalt

(and Mickey Basalt of Hook, 1981)
- Spring fluid samples

8 Stromotolites

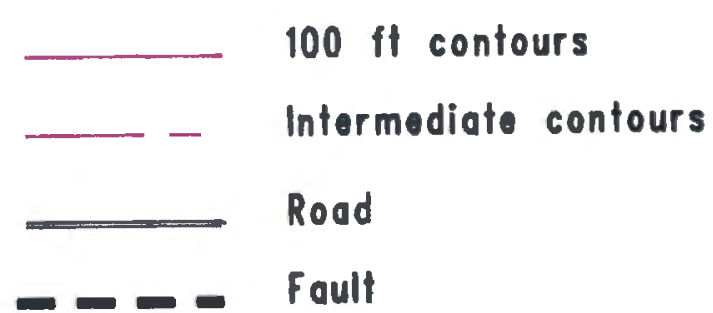

SCALE

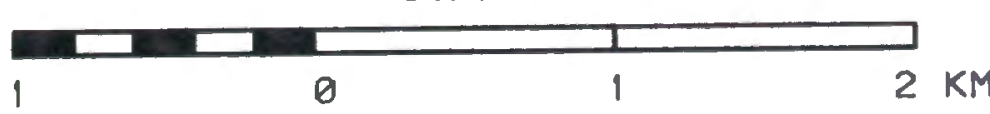


Desert and is separated from Mickey Basin to the northeast by a ridge of basalt and sediment. The hot springs occur on the east flank of a topographic high that is underlain by silica-cemented sandstone to conglomeratic sandstone. This high bounds the southwestern margin of a small depression that lies in the eastern half of the northeast-striking valley (Figure 8). Thermal features include active hot springs and pools, sinter mounds and craters, steaming ground and fumaroles.

\section{Lithology}

Cummings and St. John (1993) mapped four lithologic units that compose the Quaternary stratigraphy of the area. These include 1) lithic sandstones to conglomerate, 2) silica sinter, 3) unconsolidated bedded silts and clays, 4) well-rounded unconsolidated conglomerate, and 5) unconsolidated colluvium and alluvium. The distribution of these stratigraphic units is shown in Figure 8.

\section{Coarse- to fine-grained lithic sandstone and}

conglomerate. A small escarpment occurs immediately west of Mickey Springs; it is composed of silica cemented, coarseto fine-grained lithic sandstones and conglomerates. Similar, but generally finer grained sandstones occur east of this escarpment among the sinter terraces of the hot spring area. Petrographic analysis of these sandstones and conglomerates revealed variously textured basalt clasts, sparse plagioclase grains derived from phenocrysts in the 
basalt, and, rare rhyolite and andesite clasts (Cummings and St. John, 1993).

Sedimentary structures include cross bedding and current ripple marks. Immediately west of the active hot spring area, top-set, fore-set, and bottom-set beds are prominent. The fore-set beds are up to $1.8 \mathrm{~m}$ thick. Current ripple marks occur in moderately silicified, mediumgrained sandstone. Scour and fill cross sets in the same general area (Figure 8 ) contain masses of partially permineralized wood chips and stem fragments.

The sandstones and gravels contain fluvial cross bedding, and, in the immediate vicinity of the springs, they possess bedding characteristics typical of a Guilbert delta. Cummings and St. John (1993) observed a high percentage of silica matrix relative to framework grains for the silicified sandstones, which is consistent with sedimentation while hot springs were actively depositing silica sinter. Uranium series disequilibrium age dating yielded an age of $16,000 \mathrm{yr} . \mathrm{b} . \mathrm{p}$. for sinter interbedded with sandstone (Cummings and St. John, 1993).

Sandstone also occurs locally in the area of silica sinter deposits. Sand grains are common in dense sinter deposits in the northwestern part of the sinter area. The sandstone unit has not been observed east of Mickey Springs. Cummings and St. John (1993) place this coarse-grained unit stratigraphically below the fine-grained lacustrine 
sediments.

Cummings and St. John (1993) infer that the sandstones and gravels, fine-grained lacustrine sediments, and wellrounded cobble and pebble deposits are juxtaposed across a northeast-striking fault with estimated strike of $\mathrm{N} 40^{\circ} \mathrm{E}$ (Figure 8). They infer that this structure is the conduit for thermal waters at Mickey Springs. This fault occurs southeast of a fault of similar orientation located by Hook (1981).

Silica sinter. Silica sinter deposits are prominent at Mickey Springs although the active hot springs are not depositing silica sinter.

Cummings and St. John (1993) note the following morphologies for sinters at Mickey Springs. The sinter deposits form shield-shaped mounds that are constructed directly on fine-grained sand and sandstone. Qua quaversal dips from the crest of a deposit occur in thinly bedded to laminated, porous to dense silica sinter. The craters, forming the apex of the shield-shaped mounds, range in diameter from 1.8 to $9.0 \mathrm{~m}$ and are surrounded by aprons of steeply inward dipping porous to dense, laminated to thinly bedded pool-edge silica sinter. In most cases, the craters are infilled by younger sediment. However, in one case, the pit is at least $3.6 \mathrm{~m}$ deep and the relation of the sinter to underlying sediment is well exposed. The sinter is $1.5 \mathrm{~m}$ thick and directly overlies unconsolidated, lithic-rich, 
medium-to very fine-grained sand. The friable sand is directly overlain by wavy bedded sinter. Root casts in the sand are lined with silica and form elongate hollow tubes that are up to $7.6 \mathrm{~cm}$ long.

The sinter is composed of opal-A, amorphous silica (Cummings and St. John, 1993). In addition to opal-A, the sinter contains trace amounts of quartz and feldspar, and trace amounts of boracite. Cummings and st. John (1993) infer that the quartz and feldspar were probably introduced into the depositing sinter as wind-blown dust.

Fine-grained sedimentary deposits. Cummings and st. John (1993) mapped fine-grained clastic sediments east, north, and west of the hot spring area (Figure 8). The sediments consist of uncemented, planar bedded, silt and clay with fine-grained sand. The sediments are exposed in the banks of ephemeral streams in sections that are up to 6 m thick. The sections consist of alternating pale gray or light brown, planar to slightly wavy, laminated to thin bedded beds. From 50 to 80 beds occur per $10 \mathrm{~cm}$ of thickness. The fine-grained sediments directly onlap basalt flows in the northwestern part of the study area and are overlain by unconsolidated, well-rounded cobbles in the east and southeastern portions of the study area. To the north, the sediments are poorly exposed, but their presence is by soil color. The elevation over which the deposits occur is from approximately 1,246 to $1,274 \mathrm{~m}$. 
Similar sediments, but of silt to very fine sand sizes occur in small ravines west of Mickey Springs (Figure 8 ). The deposits are thin bedded and contain alternating very fine-grained basalt sand and light tan to brown silt. Bedding planes are planar to faintly wavy. These deposits occur to an elevation of at least 1,171 m. The lowest exposures are at approximately 1,156 m feet where they are covered by alluvium.

Cummings and St. John (1993) infer that these deposits are glacial flour that was deposited in glacial Lake Alvord. Well-rounded cobbles. Uncemented, well rounded, often flattened cobbles occur at elevations above 1,262 m north of Mickey Springs and 1,274 $\mathrm{m}$ southeast of the springs (Figure 8). Float derived from these levels occurs at lower elevations. The thickness of deposits varies from place to place and may be generally 1 to $2 \mathrm{~m}$ thick. The cobbles include a wide range of lithologic types including several textural types of basalt, rhyolite, rhyolite ash-flow tuff, and plutonic rocks. Cummings and St. John (1993) infer that these deposits represent old shorelines or beaches of glacial Lake Alvord.

Anqular colluvium. Angular basalt colluvium occurs at the base of the steep slopes that bound the basin (Figure 8). In addition, blocks up to $0.9 \mathrm{~m}$ in diameter occur far out into the basin where they directly overlie all stratigraphic units. 
Wind-blown sand. Wind-blown sand occurs on the eastern slopes of rises and, like basalt colluvium, often covers key stratigraphic relations (Figure 9). The wind blown deposits are also locally present in the depression east of Mickey Springs.

Alluvium. Alluvial deposits are present along intermittent streams that drain into the basin from the eastern side of the valley (Figure 8). These deposits merge with playa deposits over the floor of the depression east of the hot spring area (Figure 8) and cover the fine-grained sediments in this area. Playa deposits also form the valley floor southwest of the hot springs in the northeastern end of the Alvord Valley.

Cummings and St. John (1993) note that the geomorphology of the Mickey Springs area is dominated by fault-block mountains, Pleistocene lake terraces and deposits, prograding alluvial and colluvial deposits, and low areas generated by wind deflation.

\section{ALVORD HOT SPRINGS}

\section{Surface Features}

Thermal features at Alvord Hot Springs consist of a NEstriking zone of seeps located at the base of steens Mountain on the west side of the Alvord Desert. The springs are aligned along a N 21 E trend and discharge flows to the east down a gentle slope to the Alvord Desert. 


\section{Lithology}

Cummings and St. John (1993) mapped four lithologies in the vicinity of the springs: Rhyolite, silica sinter

deposits, fine-grained sediment, and unconsolidated alluvium (Figure 9).

Rhyolite. Immediately west of the hot springs are outcrops of fractured and veined rhyolite of the Pike Creek Formation previously mapped by Hook (1981) and Minor and others, (1987c).

Silica sinter deposits. Silica sinter deposits are very poorly exposed at Alvord Hot Springs. The sinter is exposed where dug into by road maintenance equipment along the east shoulder of the road that passes between the hot springs and outcrops of rhyolite. The sinter is massive, medium gray, and contains few fossil plant materials. Because of the limited exposure and outcrop disruption due to road maintenance, the geometry and extent of the deposits are not known.

Mineralogical determination by XRD indicates that the sinter is composed primarily of opal-A, but detrital grains of quartz and feldspar compose up to 5 percent of the sinter (Cummings and St. John, 1983). Trace concentrations of cristobalite, boracite, and possibly calcite are also present.

Fine-grained sediment. The immediate discharge area of the hot springs is composed of poorly exposed, interbedded 


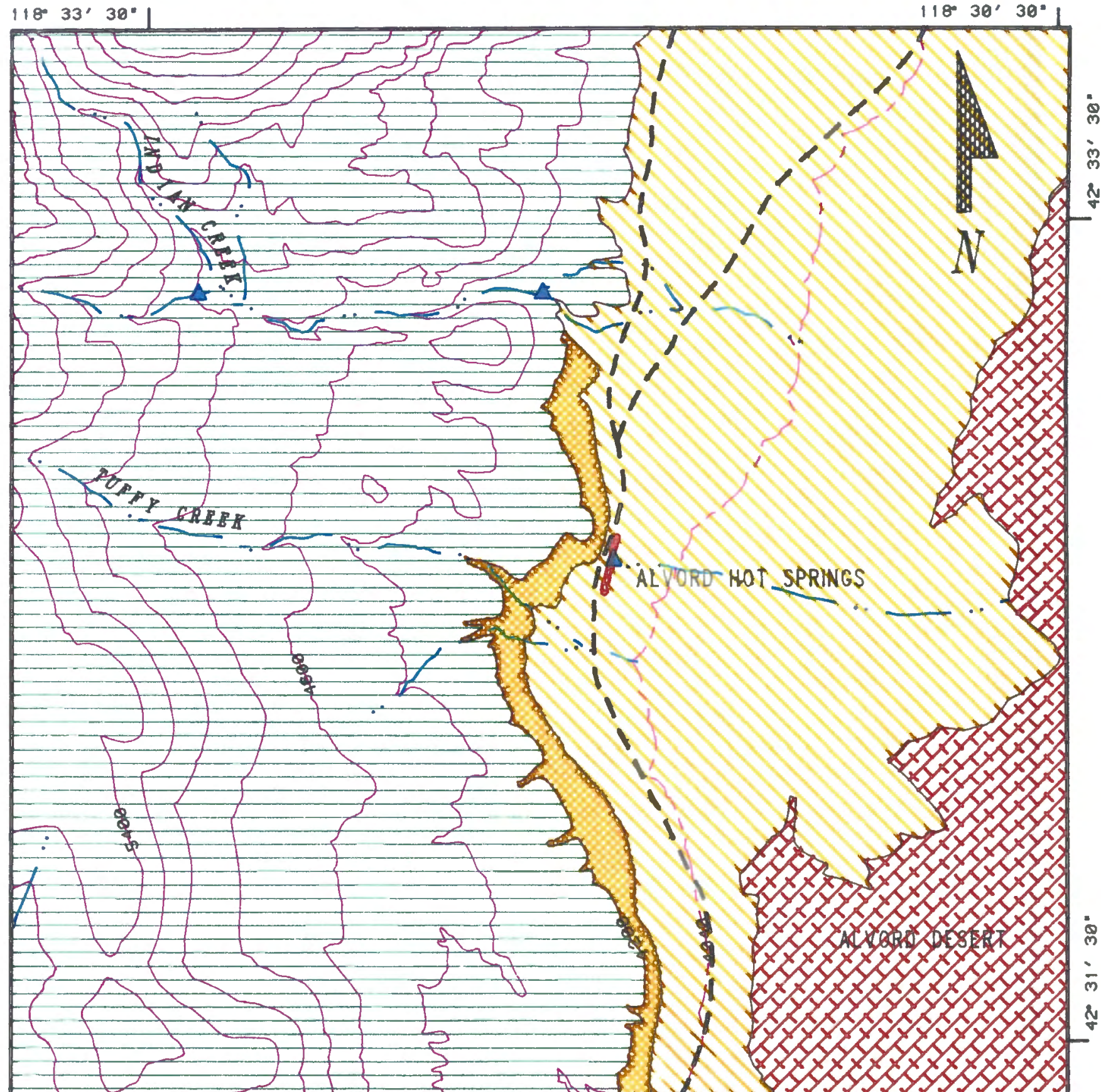

Base map digitized from

USGS 7.5' topographic

quad angle (Alvord Hot Springs).
Map covers sections $28-33$

Township $34 \mathrm{~S}$ Range $34 \mathrm{E}$

and sections 4-6 Township $35 \mathrm{~S}$

Ronge $34 \mathrm{E}$
EXPLANATION

\%

Unconsolidated alluvium

$M$

Silica sinter

Av

EXY Playa sediments

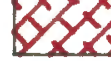

Pike Creek Formation

$200 \mathrm{ft}$. contours

Intermediate contours

Streams

- Spring fluid samples

SCALE 
sand, silt and clay. These materials are believed to underlie the slope that extends from the hot springs to the level of Alvord Desert where playa sediments are dominant. These sediments have been previously mapped as lacustrine sediments deposited in glacial Lake Alvord (Minor and others, 1987c and Hemphill-Haley et al., 1989).

The hot springs dicharge from along the Alvord fault (Hemphill-Haley et al., 1989) where it separates intermediate aged lake deposits $\left(Q 1 d_{2}\right)$ from thermal spring deposits (Qts).

The fine-grained sediments are interpreted to be an erosional remnant of the lacustrine sediments that were deposited in glacial Lake Alvord (Hemphill-Haley et al. (1989). The bulk of these sediments have been subsequently removed by wind erosion during the development of the Alvord Desert. The gentle sloping, fan shaped feature away from the hot springs may be fine-grained lacustrine sediments that have been stabilized from wind erosion by the water discharged from the hot springs (Cummings and st. John, 1993).

Unconsolidated alluvium. Unconsolidated alluvium is not abundant in the immediate area around Alvord Hot Springs. Large alluvial fans prograde from the mouths of Pike Creek and Alvord Creek north of Alvord Hot Springs (Figure 1). However, only small fans have developed at the mouths of streams that drain into the Alvord Desert 
immediately north and south of the hot springs. 
STRUCTURAL CONTROLS ON THE LOCATION OF HOT SPRINGS

A number of geophysical, heat flow, and geologic studies have been performed to investigate the relationship of hot springs to subsurface structure in Alvord basin. Griscom and Conradi (1975) performed detailed, continuous, magnetic and gravity profiles around Borax Lake, Alvord Hot Springs and Mickey Springs. An audiomagnetotelluric resistivity study was performed by Long and Gregory (1975). Gravity studies at Alvord Hot Springs and Borax Lake were performed by Cleary (1976) and seismic reflection surveys were conducted by Cleary (1976) and Anadarko Petroleum Corporation (unpublished Anadarko Petroleum Corporation reports cited by Blackwell and others, 1986). Heat flow studies were performed by Anadarko Petroleum Corporation in the vicinity of Borax Lake (Blackwell et al, 1986; Bodvarsson, 1991; Huntley, 1991). Varekamp and Buseck (1983) determined the relationship between shallow subsurface structure and the distribution of mercury at Mickey springs.

BORAX LAKE

In the section on surface features, it is indicated that Borax Lake and hot springs north of the lake occur along an N1OE zone of faults that are most easily 
interpreted as down to the east. The following geophysical studies examine these structures at depth.

Griscom and Conradi (1975) performed detailed gravity and magnetic surveys at Borax Lake using a station spacing of 100 to $200 \mathrm{~m}$. Small gravity highs ( $0.5 \mathrm{mgal})$ are associated with faults near Borax Lake. These anomalies are 0.3 to $1.0 \mathrm{~km}$ wide. Griscom and Conradi (1975) infer that the small width and narrow marginal gradients of these anomalies are caused by density differences within 100 to $200 \mathrm{~m}$ of the surface. They suggest that the highs are caused by partial cementation of the alluvium at the faults which increases the alluvium density by filling pore space with silica or calcium carbonate.

A significant amount of magnetic "noise" is evident where the magnetic traverse crosses the faults near Borax Lake (Griscom and Conradi, 1975). These anomalies are produced by increased amounts of magnetic minerals relative to background contents in the alluvium. They infer that magnetic anomalies are caused by the minor amounts of magnetic minerals at depths of less than $66 \mathrm{~m}$ in the alluvium. Griscom and Conradi (1975) note that this zone of small magnetic anomalies is associated with the weak gravity anomalies. They suggest that the association of magnetic anomalies with gravity anomalies may indicate that chemical reactions involving "hot saline waters" have generated increased amounts of magnetic minerals near the faults in 
the weakly magnetic alluvium.

Long and Gregory (1975) delineated a small resistivity minimum surrounding Borax Lake in an audiomagnetotelluric resistivity study. The minimum surrounding the hot springs occurs throughout the frequency spectra at both shallow and extreme depths. The anomaly broadens and centers on surface hot springs at the higher end of the frequency spectrum (i.e., shallower probing).

The anomaly surrounding Borax Lake shows some displacement toward the valley-bounding faults at lower frequencies (i.e., deeper probing) and a decrease in the size of the anomaly. Long and Gregory (1975) suggest that the anomaly may indicate that thermal water exits the rangefront fault in a limited area at depth and migrates down the hydrologic dip toward the center of the basin, where it appears as a zone of scattered hot springs.

Cleary (1976) performed east-west and north-south, widely spaced (distance between stations was 0.8 to $1.6 \mathrm{~km}$ ) gravity surveys to define the subsurface structure of the valley between Alvord Hot Springs and Borax Lake. He noted that the structural configuration near Borax Lake is more complicated. A buried NNE trending horst block is indicated on the profile for the survey conducted approximately $3 \mathrm{~km}$ south of Borax Lake. The eastern margin of this horst block is projected northward and is inferred to coincide with the group of hot springs north of Borax Lake (Cleary, 1976). A 
north-south profile across Borax Lake and the springs north of Borax Lake anomaly shows an anomaly directly under Borax Lake and the associated hot springs to the north. Cleary (1976) infers that a fault with moderate displacement (100$200 \mathrm{~m}$ ) occurs under the springs.

Both gravity and seismic reflection surveys (Cleary, 1976; unpublished Anadarko Petroleum Corporation reports cited in Blackwell and others, 1986) indicate that a buried north-northeast trending horst block exists beneath the area southwest of Borax Lake and the springs north of Borax Lake. Blackwell and others (1986) noted that the horst block became narrower to the north of Borax Lake, and that it may not be present north of the south end of Alvord Lake (Figure 1). The location of the NNE-trending fault that bounds the eastern margin of this intrabasinal horst block was inferred to coincide with the hot springs at Borax Lake (Cleary, 1976). However, after reprocessing of seismic data collected by Anadarko Petroleum Corporation, Robert Edmiston concludes that the hot springs north of Borax Lake and Borax Lake are not associated with the fault which bounds the eastern side of the horst block south of Borax Lake, but with a separate high-angle NNE-trending fault which parallels the NNE-trending horst south and west of Borax Lake (Robert. Edmiston, written communication, 1991). Presently, the subsurface relationship of these two faults is unknown. 
Heat flow data (unpublished contour heat flow maps of the Borax Lake area cited in Bodvarsson, 1991, 1992 and Huntley, 1991, 1992) delineate upflow zones for the Borax Lake geothermal reservoir. Bodvarsson (1991) notes that heat flow data indicate two maximum heat flow anomalies, one close to Borax Lake and the other close to the location of Anadarko Petroleum Corporation's observation well 25-22A (Figure 7). These two heat flow anomalies indicate two main upflow zones, where fluids upwell from depth, disperse in shallow regions and discharge through shallow surface manifestations (e.g. Borax Lake and the springs north of Borax Lake), or mix with shallow groundwater (Bodvarsson, 1991). Huntley (1991) argued that the above conclusions regarding the two maximum heat flow anomalies "appear to be influenced by hot springs near Borax Lake and by well 2522A, both of which represent conduits carrying hot water to the surface" (Huntley, 1992). Bodvarsson (1992) countered that the heat flow contour maps were based on data collected prior to the drilling of well 25-22A and the two main upflow zones remain even if the hot springs are removed. Presently, the hydrologic connection between the two upflow zones, if any, is unknown.

\section{MICKEY SPRINGS}

In the section on surface features, a $\mathrm{N} 40^{\circ} \mathrm{E}-$ striking fault is interpreted to control the location of the hot 
springs at Mickey Springs.

Varekamp and Buseck (1983) determined the relation between shallow subsurface geologic structure of the Mickey Springs thermal area and the observed $\mathrm{Hg}$ anomalies in the vicinity of Mickey Springs. Hook (1981) located Mickey Springs at the intersection of a $\mathrm{N}$-S-striking dike swarm and some transverse NE-striking range front faults. Peak Hg values were encountered around the hot springs and in a northeast-southwest branch, which lacks surficial expression (Varekamp and Buseck, 1983). Varekamp and Buseck (1983) interpreted the northeast-southwest branch in the anomaly pattern as a result of vapor leakage along a buried fault that serves as a conduit for hot water from deep levels. The audio-telluric pattern also shows an elongated zone with similar orientation (Brown and Peterson, 1980).

The following geophysical data are available for this site. Griscom and Conradi (1975) identified a small gravity low with a residual amplitude of $-1.4 \mathrm{mgal}$ at Mickey Springs. Griscom and Conradi (1975) note that the low suggests a small basin (depth of $75 \mathrm{~m}$ ) of alluvium, downfaulted at the hot springs. Alternatively, they note that the gravity minimum may be due to different types of volcanic bedrock with slightly differing densities that have been juxtaposed by faulting.

The audiomagnetotelluric resistivity study of Long and Gregory (1975) also delineates a resistivity minimum at 
Mickey Springs. The minimum occurs throughout the frequency spectra at both shallow and extreme depths. The anomaly broadens and centers on surface hot springs at the higher end of the frequency spectrum (i.e, shallower probing).

The anomaly at Mickey Springs shifts very little, and does not broaden at higher frequencies. Long and Gregory (1975) conclude that this anomaly suggests a direct path to the surface for ascending thermal waters and possibly a shallow depth to the source of fluids.

\section{ALVORD HOT SPRINGS}

In the section on surface features, the springs at Alvord Hot Springs are indicated to align along a N $21 \mathrm{E}$ trend. The sinter deposits at the site occur at a slightly higher elevation and immediately to the west of the modern discharge points. The following geophysical data are available for the Alvord Hot Springs.

Griscom and Conradi (1975) found that the Alvord Hot Springs are associated with a steep gravity gradient and located a major, controlling fault on gravity profiles at the steepest gradient (inflection point). Structural models by Cleary (1976) based on gravity measurements indicate that the hot springs are located directly above the western valley-bounding normal fault.

The audiomagnetotelluric resistivity study performed by Long and Gregory (1975) delineates a large resistivity 
minimum surrounding Alvord Desert. Long and Gregory (1975) suggest that the anomaly surrounding Alvord Desert results from highly conductive layers of evaporite-rich sediments and saline waters buried beneath the playa floor. In addition, they infer that this anomaly masks any anomaly associated with Alvord Hot Springs.

Hemphill-Haley et al. (1989) exposed the Alvord fault in a trench approximately $0.5 \mathrm{~km}$ north of the hot springs. The fault is a high-angle normal fault that dips $72^{\circ} \mathrm{E}$ and contains several strands within a zone about $2 \mathrm{~m}$ wide. 
GEOTHERMAL RESERVOIR CONDITIONS

The conditions within the geothermal reservoir for the three thermal areas were investigated through the use of chemical and isotopic methods. These methods assess the recharge and age of the geothermal fluids, the host rock of the reservoir, and the temperature of reservoir fluids, and provide basic constraints on models for the geothermal systems in the Alvord basin.

\section{CHEMISTRY OF NON-THERMAL AND THERMAL WATERS}

The chemical constituents in thermal and non-thermal waters are derived primarily from the country rock by dissolution of, or exchange with, the rock-forming minerals (Ellis and Mahon, 1964; 1967). If the fluid and the rock have equilibrated in the reservoir, the chemical composition of the fluid contains a record of the conditions of equilibrium. If during ascent to the surface, the fluid is not strongly modified by boiling or mixing, this composition maintains the signature of the reservoir conditions. The reservoir conditions are estimated from the elemental and isotopic composition of the thermal water.

The general chemical characteristics of the thermal and non-thermal waters in the Alvord Valley KGRA are similar (Table III and IV); they can be classified as $\mathrm{Ca}-$ or $\mathrm{Na}-\mathrm{HCO}_{3}$ 
waters. Mariner et al. (1983) note that dilute Ca- or Na$\mathrm{HCO}_{3}$ waters develop in areas where the rock contains appreciable sodium silicate or sodium aluminosilicate minerals, such as plagioclase feldspar and volcanic glasses, and $\mathrm{CO}_{2}$ is available. A possible reaction includes $\mathrm{Na}-\mathrm{Ca}-$ mineral $+\mathrm{CO}_{2}+\mathrm{H}_{2} \mathrm{O}=\mathrm{Na}^{+}+\mathrm{HCO}_{3}^{-}+\mathrm{H}$ mineral.

Temporal Variations in Water Chemistry

Seasonal variations in fluid chemistry for thermal and non-thermal waters are minor (Figures 10 and 11 ). The cold water in the Thomas well has the highest bicarbonate and potassium contents. Sulfate concentrations decreased in Alvord Ranch spring water over time. Sodium, bicarbonate and fluoride concentrations exhibit the greatest seasonal variations in fluids from Borax Lake and the springs north of Borax Lake. Fluoride concentrations in thermal springs are lower in the winter months and higher in the summer months at Borax Lake, springs north of Borax Lake and Mickey Springs. Sodium concentrations decreased over time in the thermal springs and remained relatively constant in the cold springs and welis. Potassium, calcium, magnesium, boron and lithium remained relatively constant in the thermal springs during the sampling period.

Chloride concentrations remain relatively constant for cold waters and thermal waters. White (1970) argued that variations in chloride content greater than 10 percent suggest mixing of thermal water with cold water springs and 
TABLE III

CHEMICAL COMPOSITION OF COLD WATER SPRINGS AND WELLS IN THE ALVORD BASIN

\begin{tabular}{|c|c|c|c|c|c|c|c|c|c|c|c|c|c|c|c|c|c|c|}
\hline \multirow[t]{2}{*}{ Spring } & \multirow[t]{2}{*}{ Date pH } & \multicolumn{12}{|c|}{ T $\$ Cherical Constiments } & \multicolumn{5}{|c|}{ Dissolned Elementel Ratios } \\
\hline & & & $\mathbf{H}$ & $\boldsymbol{K}$ & a & $\mathrm{Mg}$ & 9 & Ba & a & B Li & $\mathbf{F}$ & SO, & $\infty_{3}$ & $\mathrm{HCO}_{3}$ & 50 & $\mathrm{BHCH}$ & 0,0 & SO/ct \\
\hline 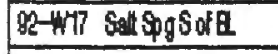 & 128977.84 & $B-8$ & $\infty$ & 12 & 13 & 0.18 & 0.07 & 0.01 & 24 & 150.044 & 0.8 & 40 & & 10 & 51 & 0.00 & 5 & 2 \\
\hline (29-1) Kutt wel (52m) & 10.007 .56 & 120 & $\$$ & 24 & 0.8 & 17 & 0.00 & $<0.02$ & 11 & 0.5 « \&.0.1 & 0.3 & $\$$ & & 2 & 6? & 0.06 & 2 & 2 \\
\hline g2-74 Kutt wal (52) & 02821 & 17.3 & 3 & 18 & 8.3 & 14 & & & 11 & 0.30 .02 & 0.18 & W. & & ton. 3 & 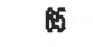 & 0.00 & 2 & \\
\hline $22-W 7 P 2$ Kutt wl (52m) & 0281 & 15.6 & 38 & 21 & 6.4 & 12 & & & 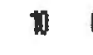 & 0.204 .07 & 0.31 & 8.7 & & 27.4 & 67 & 0.08 & D & \\
\hline 30-4027 Kut vol (32m) & Q928 817 & 15.8 & 4 & 24 & 7.7 & 16 & & & 11 & $0.8 \times 1.07$ & 0.2 & 8.5 & & \pm 1.3 & 68 & 0.00 & 2 & 2 \\
\hline 91-WTos Worde Place & 00018.03 & 15.5 & $n$ & 24 & 41 & 21 & & & 48 & 0.1440 .07 & 40.1 & 8.1 & & 2070 & & 0.08 & 53 & 2 \\
\hline $9+478$ Rum Rech (win) & 0001 & 13 & 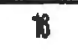 & 13 & 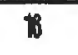 & 5.3 & & & 24 & 0.080101 & 4.1 & 28 & & 114 & & 0.08 & 4 & \\
\hline 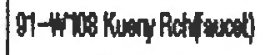 & 094 & 10 & 11 & $\$ 1$ & 24 & 7.8 & & & 6.9 \& & $0.04 \quad 6.07$ & $\$ 0.1$ & t2 & & 111 & & & $x$ & 2 \\
\hline se-wh Kuery Rech (spos) & 12801781 & 13.4 & n & 15 & 苗 & 5.9 & 0.000 & $\angle 0,02$ & 1 & 0.0 .00 .07 & $\$ 0.1$ & 17 & & 07 & 51 & 0.0 & D? & 2 \\
\hline 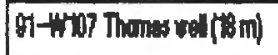 & 0.048 .59 & 104 & ton & 0.3 & 3.3 & 2 & & & 2 & 140.07 & 12 & 17 & & 363 & & 0.06 & $n$ & 10 \\
\hline 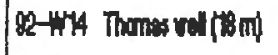 & 120184 & 129 & 10 & 23 & 25 & 18 & 0.014 & 20,002 & t2 & 14001 & 11 & 15 & 1 & $\$$ & 03 & 0.08 & 31 & \\
\hline 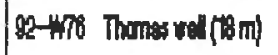 & 2028281 & 14.4 & 10 & 3.2 & 3.2 & 21 & & & 24 & 10001 & 114 & 13 & & 370.4 & $\infty$ & 0.08 & 30 & \\
\hline 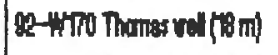 & 0.6828 .55 & 152 & 114 & 28 & 27 & 17 & & & 22 & 0.8401 .07 & 208 & 13 & & 305.5 & 54 & 0.07 & 30 & \\
\hline 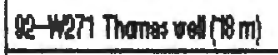 & 09028.48 & 15.4 & $2 ?$ & 3.1 & 28 & 18 & & & 2.5 & $1=0.01$ & 17 & 14 & & 151.3 & 5 & 0.08 & 11 & 0 \\
\hline 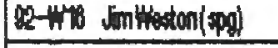 & 1201825 & 3.1 & 3 & 18 & 5.4 & 2 & 0.02 & 80,00 & 19 & 0.00 .0 .05 & $\$ 1.1$ & 5.8 & & $\omega$ & 50 & 0.04 & $m$ & 3 \\
\hline 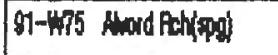 & 94 & 15 & 5 & 0.5 & 5.5 & 28 & & & 0.34 & $004 \quad 50.07$ & 40.1 & 0.8 & & 417 & & & 19 & 2 \\
\hline st-wteo Arod Athispol & 00918.79 & 19 & 5 & 3.2 & 54 & 28 & & & 16 & 0.00 .07 & 0.2 & 14 & & $\$ 2.4$ & 30 & 0.04 & 27 & \\
\hline 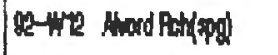 & 1209 & 8.3 & 5 & 1 & 5.8 & 28 & 0.011 & $<0,02$ & 0.4 & 0.78 allot & $\$ 0.1$ & 0.9 & & $\$ 1.4$ & 30 & 0.4 & 109 & \\
\hline 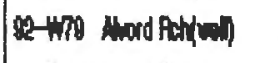 & ane 700 & 8.3 & 5 & 1 & 5.4 & 28 & & & 0.81 & $0.00 \times 1.07$ & 41 & 114 & & 4.15 & $2 ?$ & 0.11 & 56 & \\
\hline 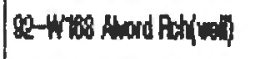 & ane 730 & 223 & 4 & 12 & B. & 3.6 & & & 10040 & 0.4 s.101 & 0.2 & 101 & & 00.27 & 32 & & 5 & \\
\hline 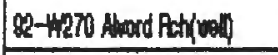 & 7.16 & 20.7 & 4 & 0.88 & 48 & 28 & & & 0.8 & 0.150 .07 & 01 & 0.8 & & 4. 2 & 28 & $0 . \pi$ & $\pi$ & 1 \\
\hline 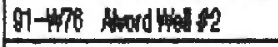 & 069 & 125 & 50 & 49 & 7.81 & 0.91 & & & 5.4 & 0.480 .077 & 0.8 & 0.5 & & 178 & & 0.00 & 33 & 0 \\
\hline $2 x-10$ cond 1 p & 12401795 & 27 & 200 & B & 11 & 7.8 & 0.00 & $<0,02$ & 80 & 3.40 .4 & 27 & 71 & & 22 & $\infty$ & 0.04 & 5 & \\
\hline$m-w+1$ lonaned spgNLS & 0.9818 .81 & 15.1 & 30 & 2 & 27 & 18 & & & $m$ & 490.008 & 5.5 & 85 & & 500 & & 0.06 & 5 & \\
\hline 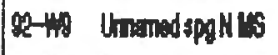 & 180018.68 & 14.4 & $\infty$ & 11 & 22 & 18 & 0.000 & $S O P R$ & $\infty$ & 430.009 & 17 & 73 & 19.8 & $\infty$ & 4 & 0.06 & 6 & \\
\hline 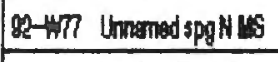 & 02028.73 & 1.7. & 200 & 0 & 24 & 10 & & & 2 & 440.008 & 19 & 742 & 18.84 & $5 \pi 12$ & $\$$ & 0.06 & 5 & \\
\hline Scouber (monk" & 1980.59 & & 254 & & 30 & 22 & & & 140 & & $\$ 2$ & & 101 & & 41 & & & \\
\hline Indencoustit & 19.52 & & $n<$ & & 243 & 0.1 & & & 40 & & $\$ 2$ & & 43 & & 4 & & & \\
\hline
\end{tabular}


TABLE IV

CHEMICAL COMPOSITION OF THERMAL WATER

IN THE ALVORD BASIN

\begin{tabular}{|c|c|c|c|c|c|c|c|c|c|c|c|c|c|c|c|c|c|c|c|c|c|c|c|}
\hline \multirow[b]{2}{*}{ loction } & \multirow[b]{2}{*}{ Date pH } & \multirow[b]{2}{*}{$T \cdot C$} & \multirow[b]{2}{*}{$\mathbf{m}$} & \multirow[b]{2}{*}{$\mathbf{K}$} & \multirow[b]{2}{*}{$\mathbf{G}$} & \multirow[b]{2}{*}{$\mathrm{m}$} & \multirow[b]{2}{*}{ St } & \multirow[b]{2}{*}{ Bi } & \multirow[b]{2}{*}{ G } & \multirow[b]{2}{*}{ B } & \multirow[b]{2}{*}{$\mathbf{l}$} & \multirow[b]{2}{*}{$\mathbf{F}$} & \multirow[b]{2}{*}{$\mathrm{sO}_{\mathrm{i}}$} & \multirow[b]{2}{*}{$\infty_{3}$} & \multicolumn{4}{|c|}{ Dianolued Elenental Ratios } & \multirow[b]{2}{*}{ chang } & \multirow[b]{2}{*}{ Ging } & \multirow[b]{2}{*}{ Cong } & \multirow[b]{2}{*}{ Gollin } & \\
\hline & & & & & & & & & & & & & & & $\mathrm{HCO}_{3}$ & 50 & BNG & sojet & & & & & F/C \\
\hline andipos & & & & & & & & & & & & & & & & & & & & & & & \\
\hline 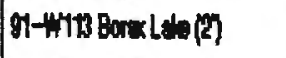 & ond $7.31^{*}$ & 3 & 40 & 27 & 4 & 0.28 & & & 20 & 1 & 0.50 & 8.7 & $3 n$ & & 44 & & 0.06 & 128 & 12 & 10 & 54 & 0.08 & 0.00 \\
\hline 97-H112 Borx Ldep(p) & and $70^{*}$ & 30 & 40 & 24 & H & 0.24 & & & 250 & bo & 0.4 & 8.9 & 320 & & 40 & & 0.06 & 18 & 100 & w & 58 & 0.08 & 0.04 \\
\hline 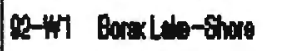 & $1297.1 .90^{*}$ & 21.7 & 3 & 23 & t & 0.2 & 0.40 & 0.06 & 240 & 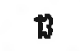 & 0.4 & 28 & 2000 & & 27 & $m$ & 0.06 & $t B$ & 18 & $m$ & 5 & 0.08 & 0.01 \\
\hline 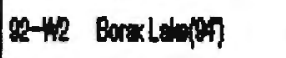 & $1247.14 *$ & $01-6$ & 350 & 21 & 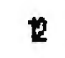 & 0.2 & 0.7 & 0.0. & 240 & 11 & 0.4 & 3.3 & 200 & & 41 & $m$ & 0.05 & $1 B$ & $1 \%$ & 10 & 0 & 0.08 & 0.01 \\
\hline $92-43$ Borrelalej45] & $12917.37 t$ & 127 & 300 & 24 & t) & 0.21 & 0.3 & 0.06 & 240 & 11 & 0.4 & 28 & 240 & & 401 & $m$ & 0.06 & 10 & 10 & $1+3$ & ne & 0.08 & 0.01 \\
\hline 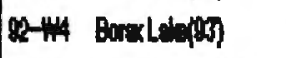 & $120017.3 x^{*}$ & $\infty$ & 40 & 22 & H & 0.24 & 0.4 & 0.0 & 240 & 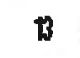 & 0.4 & 26 & 200 & & 401 & 210 & 0.06 & 108 & 167 & 1000 & 58 & 0.04 & 0.01 \\
\hline 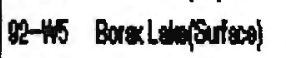 & $12017.35^{2}$ & 2.0 & 40 & 23 & 4 & 0.28 & 0.48 & 0.0 & 200 & $B$ & 0.4 & 28 & $2 n$ & & 30 & $m$ & 0.05 & to & 103 & $m$ & 81 & 0.04 & 0.01 \\
\hline 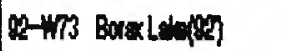 & 70.02 & $41-m$ & 40 & 25 & 4 & 0.4 & & & 24 & 14 & 0.50 & 3.0 & 201 & & $3 M$ & 187 & 0.06 & tn & 1003 & $\mathrm{~m} 1 \mathrm{l}$ & 58 & 0.08 & 0.01 \\
\hline 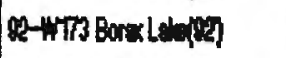 & $\operatorname{cosect} 6 t^{*}$ & $\omega-\pi$ & 310 & 20 & 11 & Q. 8 & & & 222 & 114 & 0.3 & 8.5 & 20 & & 508 & 24 & 0.06 & tix & 210 & 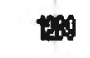 & 81 & 0.18 & 0.04 \\
\hline 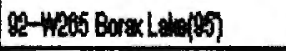 & ond $8.77^{*}$ & 106 & 307 & 21 & 11 & 0.2 & & & 250 & 28 & 0.5 & a. & 30 & & 525 & $m$ & 0.06 & to & $2 \pi$ & 1150 & 50 & 0.08 & 0.00 \\
\hline $97-474$ SprodBat & MN & 9 & 37 & 24 & 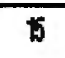 & 0.3 & & & 230 & 5 & 0.48 & 7.5 & 300 & & 47 & & 0.07 & 23 & 10 & 50 & 38 & 0.06 & 0.09 \\
\hline O1- & apd 7.00 & $\$ .3 .3$ & 400 & 25 & 10 & 0.3 & & & 240 & 4 & 04 & 7.6 & 300 & & 03 & & 0.06 & 125 & 200 & $R T$ & 4 & 0.04 & 0.08 \\
\hline R2- Epr Hor & 12017.01 & $\$ 44$ & 30 & 23 & w & 0.2 & 0.6 & 0.06 & 200 & 2 & 0.4 & 23 & 250 & & 5n & $\pi 8$ & 0.06 & tom & 288 & 710 & 4 & 0.94 & 0.00 \\
\hline 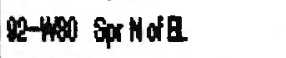 & cospe 7.10 & $\$ .6$ & 40 & 22 & 18 & 0.34 & & & 24 & $t$ & 0.48 & 28 & 2 & & 44 & $m$ & 0.00 & 108 & 18 & 78 & 4 & 0.04 & 0.01 \\
\hline 22-WTT Sp Holl & ond 49 & 204 & 270 & 20 & t) & 0.2 & & & 24 & $n d$ & 0.3 & 8.3 & $w 0$ & & 33 & 201 & 0.06 & to & $1 n$ & the & 5 & 0.06 & 0.4 \\
\hline 222-H2065 Sp Hor H & 02808 & 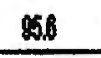 & 30 & 20 & 2 & 0.3 & & & 250 & 0.8 & 0.4 & 6.3 & 30 & & $4 \pi$ & & 0.14 & 124 & 18 & 833 & 4 & 0.14 & 0.08 \\
\hline 91-HT Nond Ho & 001 & $\pi$ & 90 & 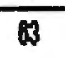 & 5 & 2 & & & 80 & 3 & $2 \pi$ & 8.1 & 2010 & & 879 & & 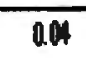 & 0.24 & 108 & 45 & 3 & 0.07 & 0.01 \\
\hline O1-WTos Mood HS & 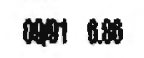 & 780 & 970 & 02 & 1 & 2 & & & $m$ & 30 & 200 & 20 & $m$ & & 235 & & 0.04 & 0.24 & t帅 & 36 & 8 & 0.01 & 0.01 \\
\hline R-W14 Aondhs & 12017.08 & 7.8 & $\$ 0$ & 0 & D & 2 & 0.2 & 0.01 & 780 & $\theta$ & $2 n$ & 5.4 & $m$ & 223 & 24 & $\mathbf{m}$ & 0.00 & 0.2 & 19 & 30 & 5 & 0.01 & 0.01 \\
\hline (22-W75 Aod Ho & ande 8.81 & 780 & 200 & 58 & 2 & 2 & & & 759 & $x$ & 201 & 21 & $m$ & & Des & tot & ent & 0.28 & 10 & 379 & 6 & 0.07 & 0.00 \\
\hline 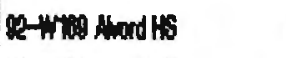 & ande 7.10 & 5.1 & 804 & $n$ & 11 & 2 & & & 754 & 27 & ts & 20 & $\pi$ & & 2002 & 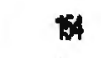 & 0.00 & 0.23 & 108 & $m$ & b & 0.01 & 0.0 \\
\hline D-Has Aoxd HS & 0908.81 & 7.8 & 783 & 54 & 0 & 2 & & & $\infty$ & 23.7 & 103 & 2.0 & 25 & & 1418 & 故 & 0.00 & 0.8 & $1 \pi$ & $\$ 0$ & 5 & 0.01 & 0.01 \\
\hline 91-wh Vheq Spings & 6098 & 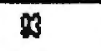 & 59 & 31 & 1 & $0 . \pi$ & & & 220 & 11 & 0.78 & 50 & 20 & & 80 & & 0.06 & 0.6 & 416 & 24 & 6 & 0.0 & 0.0 .7 \\
\hline Di-Why letheg Spring & 0018.30 & 0.4 & 59 & $y$ & 0.70 & 0.04 & & & 20 & 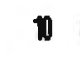 & 0.80 & 1.0 & 200 & & 62 & & 0.06 & 0.65 & 425 & 5050 & n & 0.00 & 0.08 \\
\hline 20-w11 vakeg Springs & 10 & $02-16$ & 40 & 28 & 1 & 1 & 0.15 & Q.e & 20 & 84 & 0.80 & 43 & 10 & 9 & 80 & 252 & 0.04 & 0.22 & 430 & 200 & 1 & 0.00 & 0.0 \\
\hline (x-478 vale springs & 2008 & 94 & 40 & 24 & 0.8 & Q.A. & & & $2 \pi$ & 8.7 & 0.78 & 55 & $m$ & 67 & 80 & 25 & 0.04 & 0.82 & 3.90 & sins & 20 & 0.0 & 0.00 \\
\hline 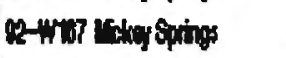 & axp 250 & M. & 49 & 25 & 0.68 & a.e & & & 20 & 7.8 & 0.7 & $\pi g$ & 178 & 0 & 69 & 230 & 0.04 & 0.5 & 3.0 & 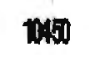 & 34 & 0.00 & 0.00 \\
\hline 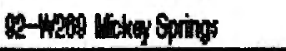 & 98.43 & $\infty$ & 49 & 27 & 0.28 & 0.07 & & & 20 & 9.6 & $0 . \pi$ & t..4 & 20 & $\infty$ & 600 & 20 & 0.04 & 0.05 & 7.30 & $3+3$ & 2 & 0.00 & 0.07 \\
\hline Trips & & & & & & & & & & & & & & & & & & & & & & & \\
\hline 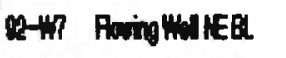 & 1200 & 586 & 3 & 23 & 2 & 1 & 0.8 & 0.03 & 20 & e & 0.4 & 22 & 200 & & 390 & 253 & 0.6 & 106 & $1 \pi$ & 20 & e & 0.08 & 0.01 \\
\hline R-W267 Aloving WIER & ane 451 & 59 & 300 & $x$ & 11 & 1 & & & 200 & $n .3$ & 0.33 & 59 & 200 & & 397 & 240 & 0.04 & 12 & $1 \pi$ & 200 & 11 & 0.04 & 0.00 \\
\hline & $\mathrm{pHr}$ & & & & & & & & & & & & & & & & & & & & & & \\
\hline
\end{tabular}




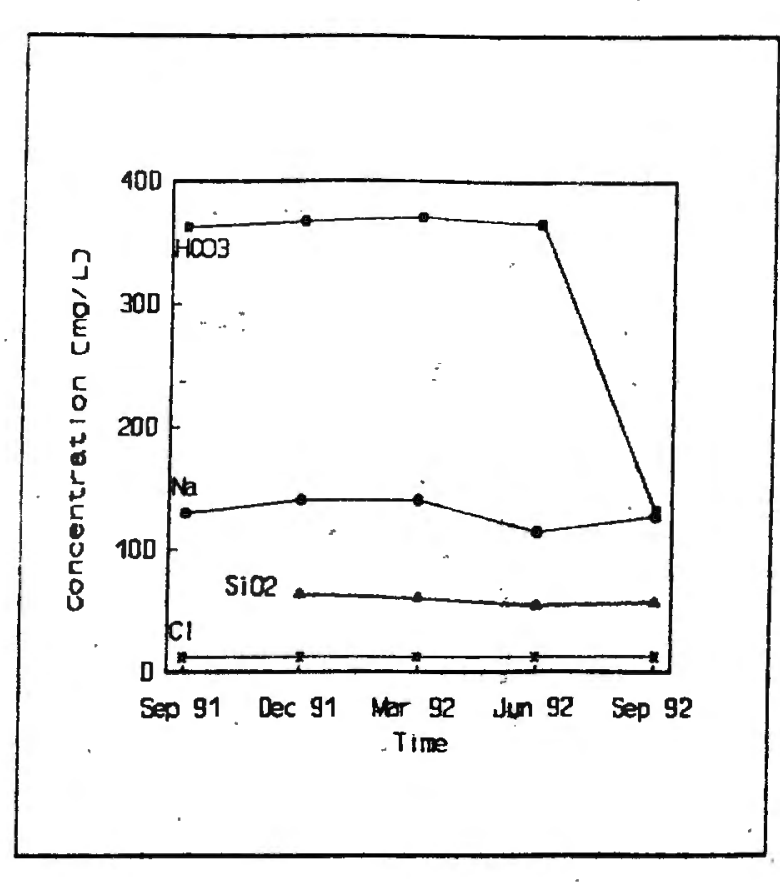

a
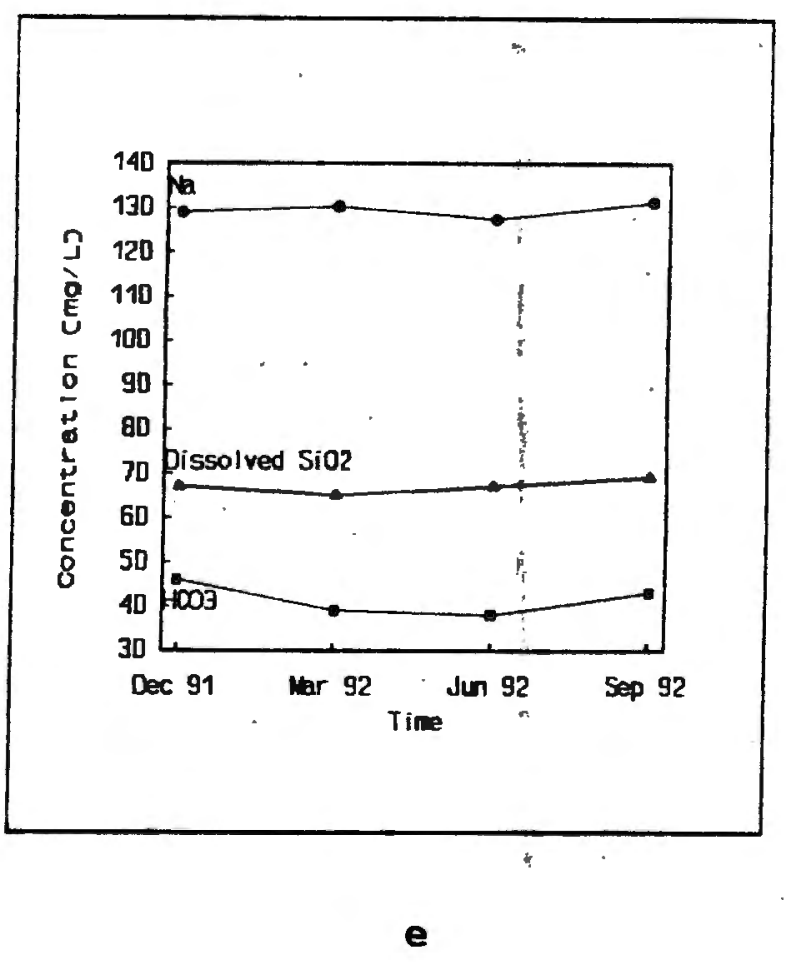

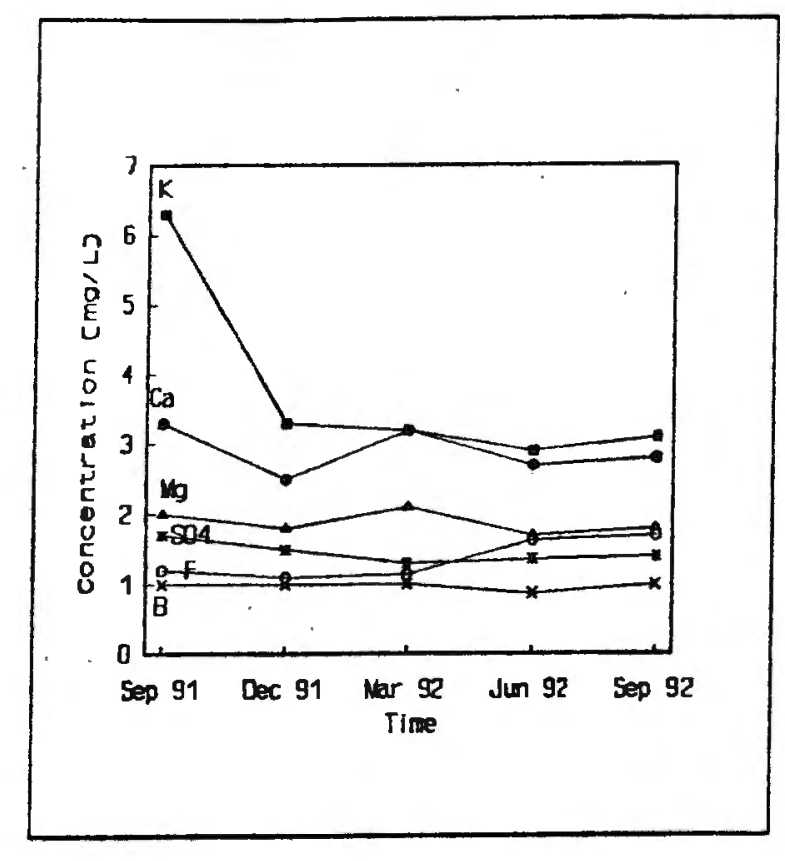

b
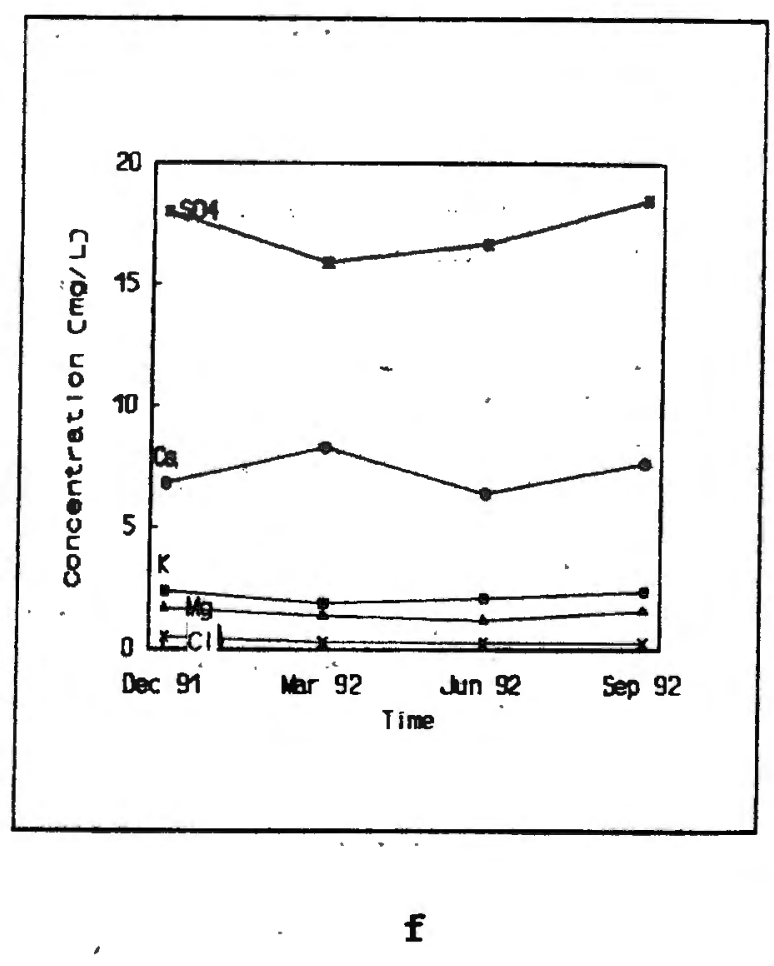

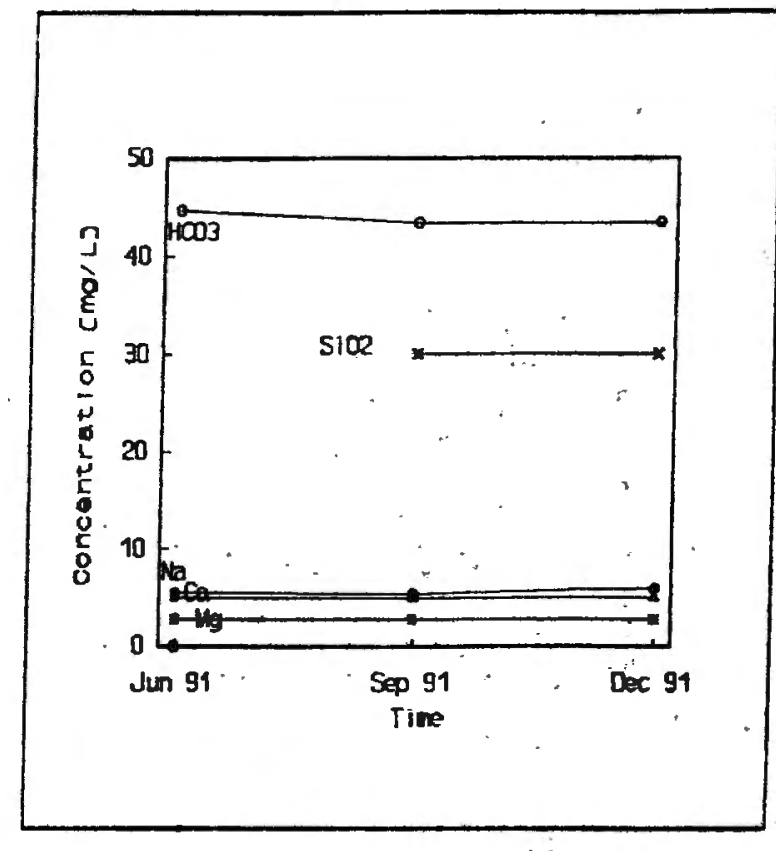

c

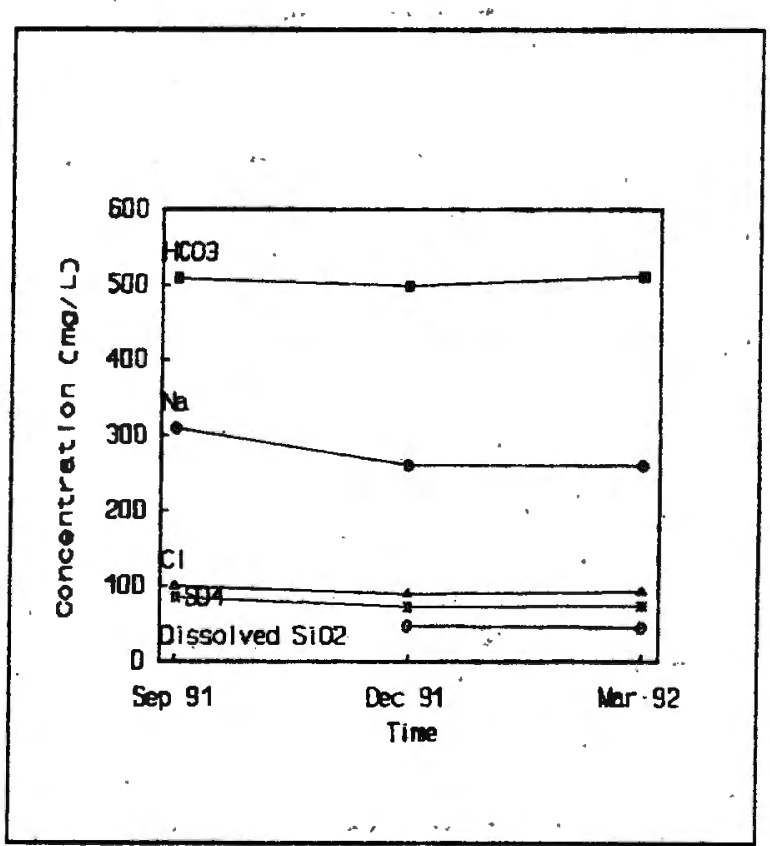

g.

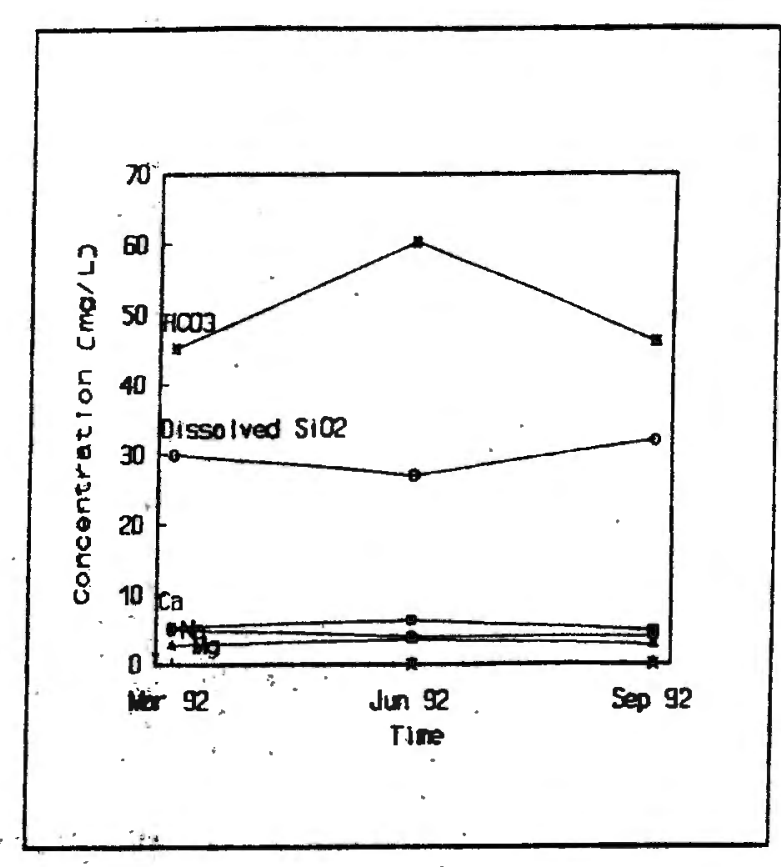

d

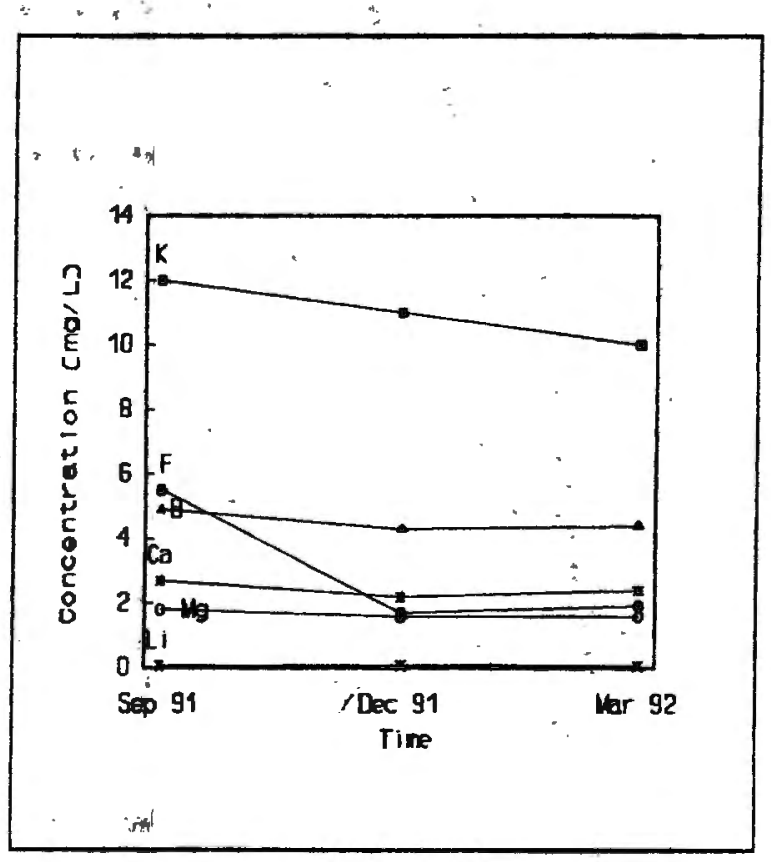

h

Fiqure 10. Seasonal variations in fluid chemistry for cold waters:

a) major constituents, Thomas well, b) minor constituents, Thomas well, c)
chentical constituents, Alvord Ranch spring, d) chemical constituents, Alvord

Ranch well, e) major constituents, Kurtz well, f) minor constituents, Kurtz
well, g) major consti tuents, unnamed springs north of Mickey Springs, and $h$ )

minor constituents, unnamed spring north of Mickey Springs. Springs, and $\mathrm{h}$ ) 


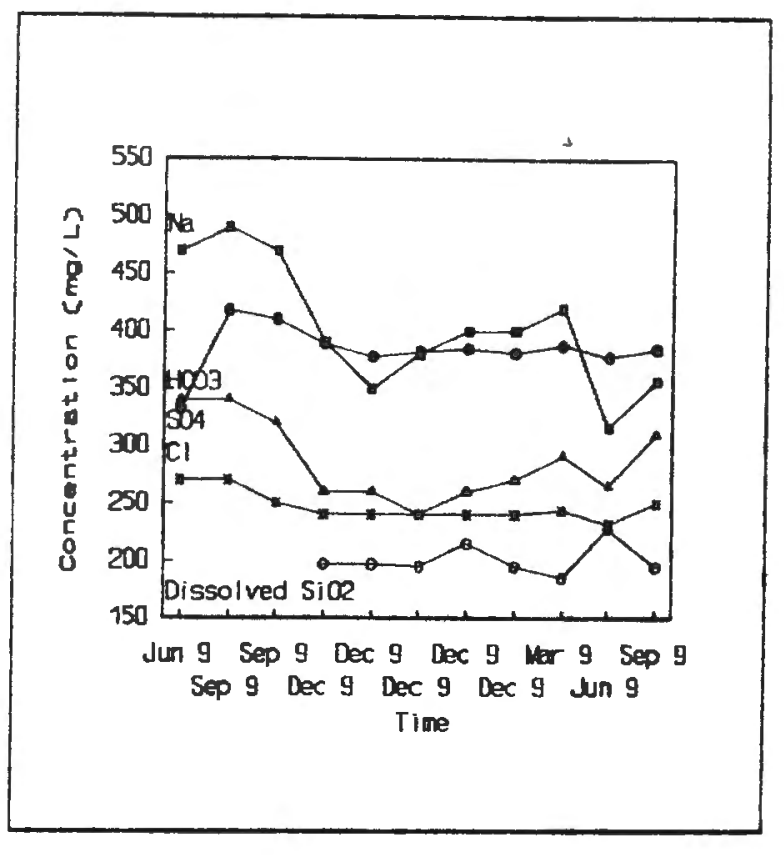

$\mathbf{a}$

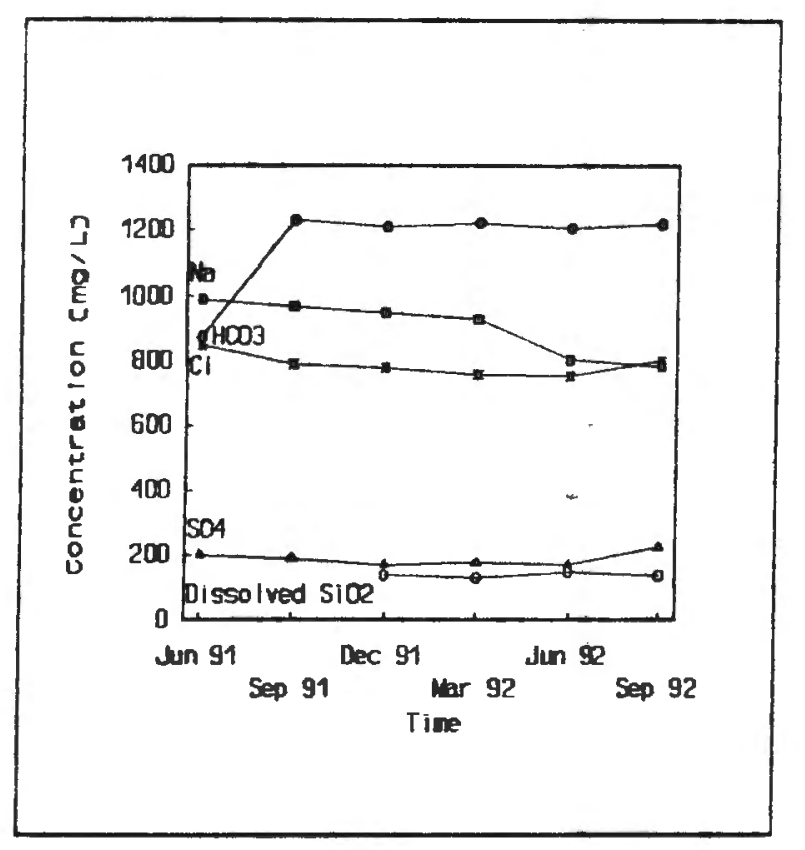

e

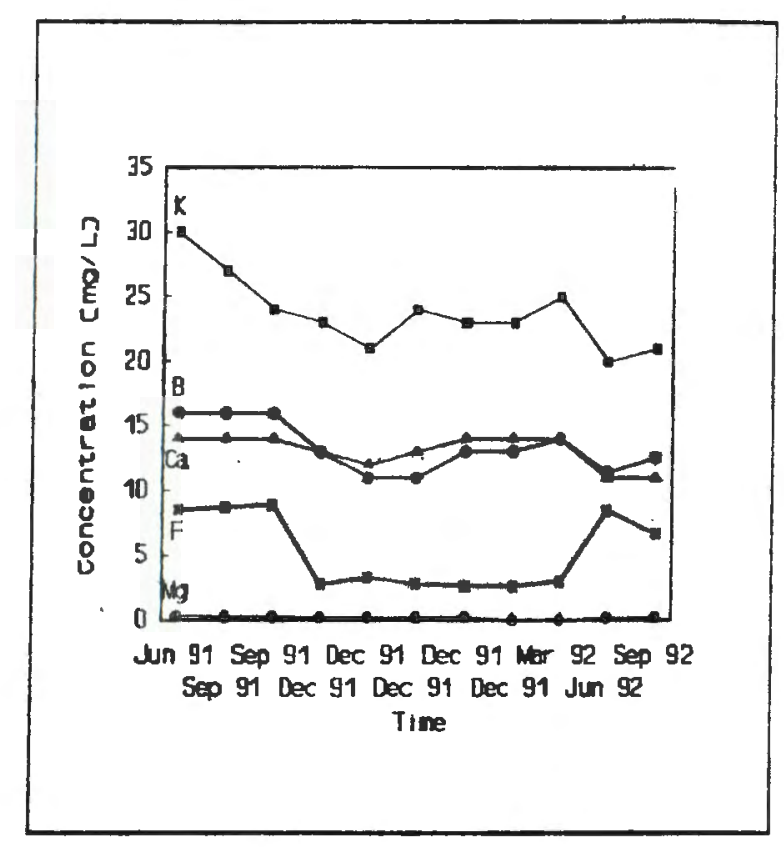

b
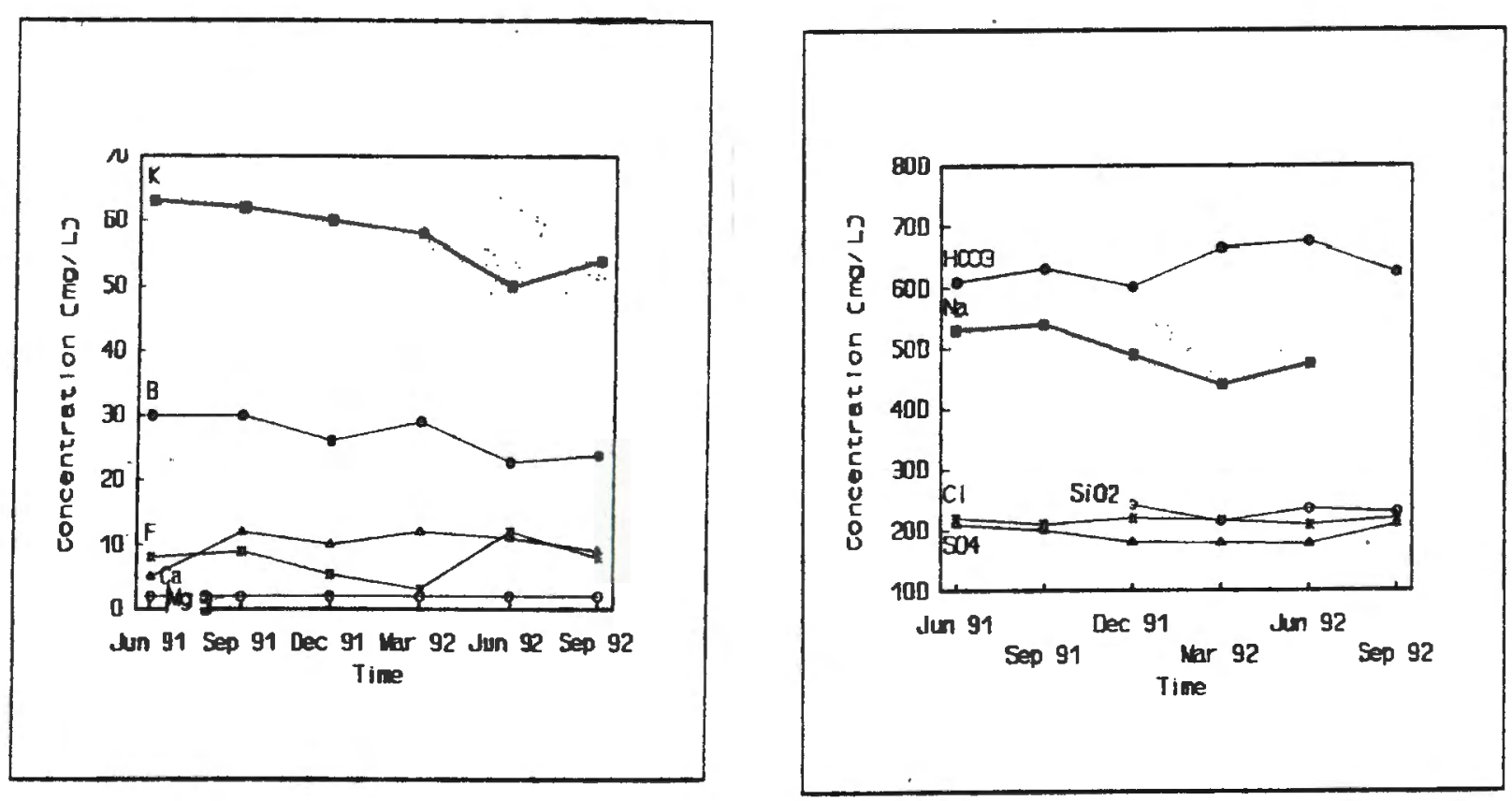

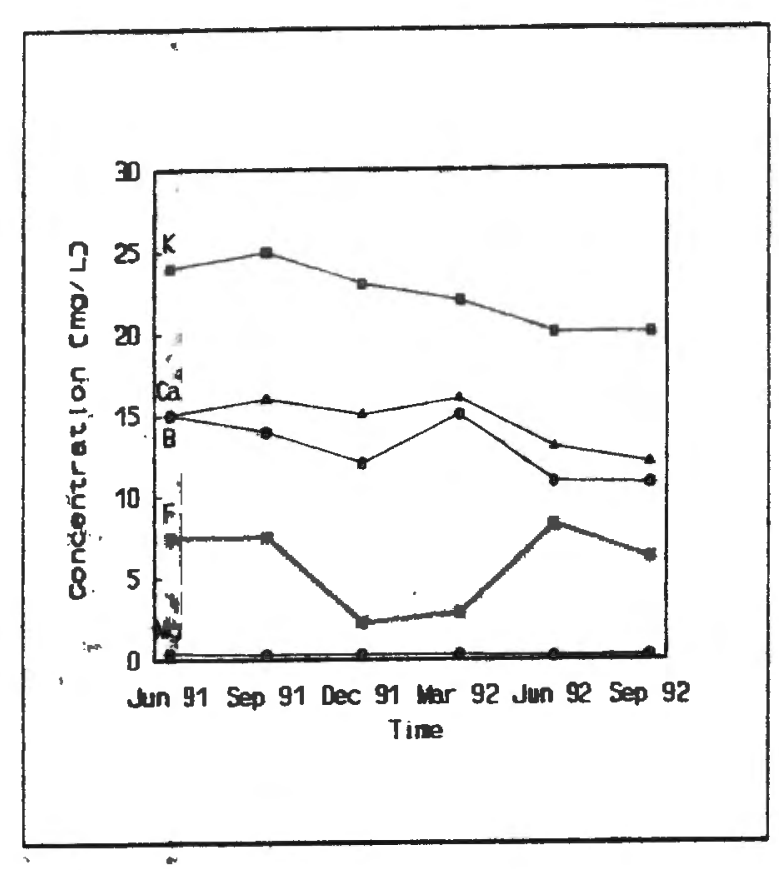

a

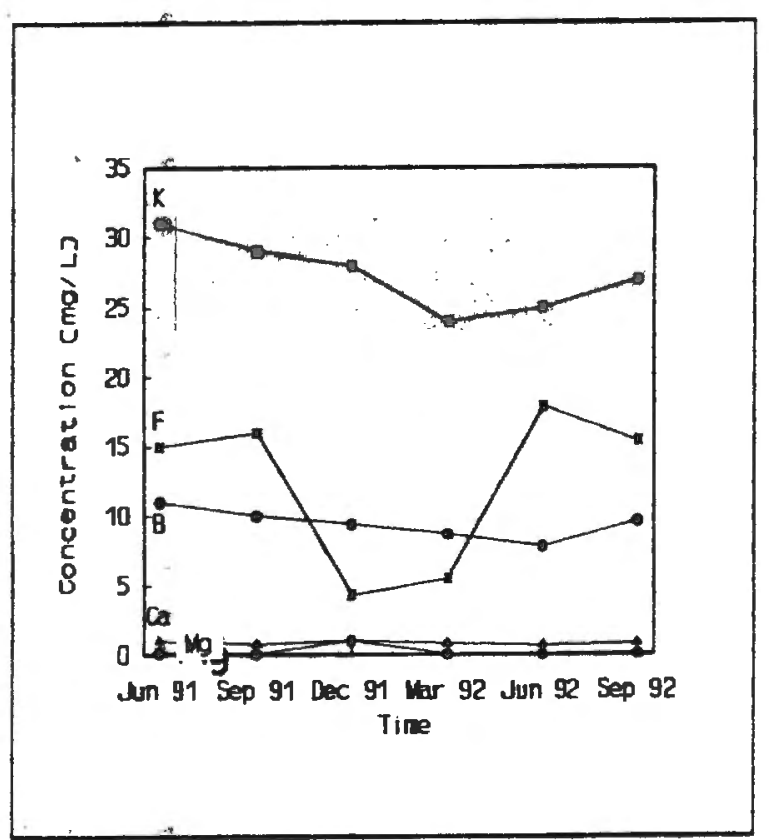

h

Figure 11. Seasonal variations in fluid chemistry of thermal waters: a) major constituents, springs north of Borax Lake, d) minor constituents, springs north of Borax Lake, e) major constituents, Alvord Hot Springs, f) minor constituents, Alvord Hot Springs, g) major constituents, Mickey Springs, and h) minor 
wells. Table $\mathrm{V}$ presents the changes in chloride content over time for cold and thermal water sites in the Alvord basin. The relatively small changes in chloride content during the sampling period suggest mixing of fluids of different compositions and temperatures is not a dominant process in the Alvord basin fluids, except in the Alvord Ranch spring and well.

Chemical variations in thermal fluids sampled from 1953 to the present (Appendix, Table XIV) are minor. The concentrations of major and minor constituents remained relatively constant for each spring over the last 40 years.

\section{Chemistry of Non-thermal Waters}

The chemistry of the non-thermal water is presented on a Schoeller diagram (Figure 12) in which, for each sample, a line connects points calculated as the $\log _{10}$ of the concentration of each constituent. Where the lines connecting points for two samples are parallel, the constituents have the same ratio in the two samples.

Non-thermal waters in the Alvord basin are generally more dilute than thermal waters (Tables III and IV). The dominant cation is $\mathrm{Na}$. The unnamed spring north of Mickey Springs and the Thomas well have the highest concentration of $\mathrm{Na}, \mathrm{HCO}_{3}, \mathrm{Cl}$ and $\mathrm{SO}_{4}$ of all the cold springs sampled. Magnesium concentrations are higher in the Kurtz well and the Thomas well than in other cold waters. Water from the Thomas well and an unnamed spring in Mickey Basin are more 
TABLE V

SEASONAL VARIATIONS IN CHLORIDE CONCENTRATIONS IN COLD WATER SPRINGS AND WELLS AND THERMAL SPRINGS IN THE ALVORD BASIN

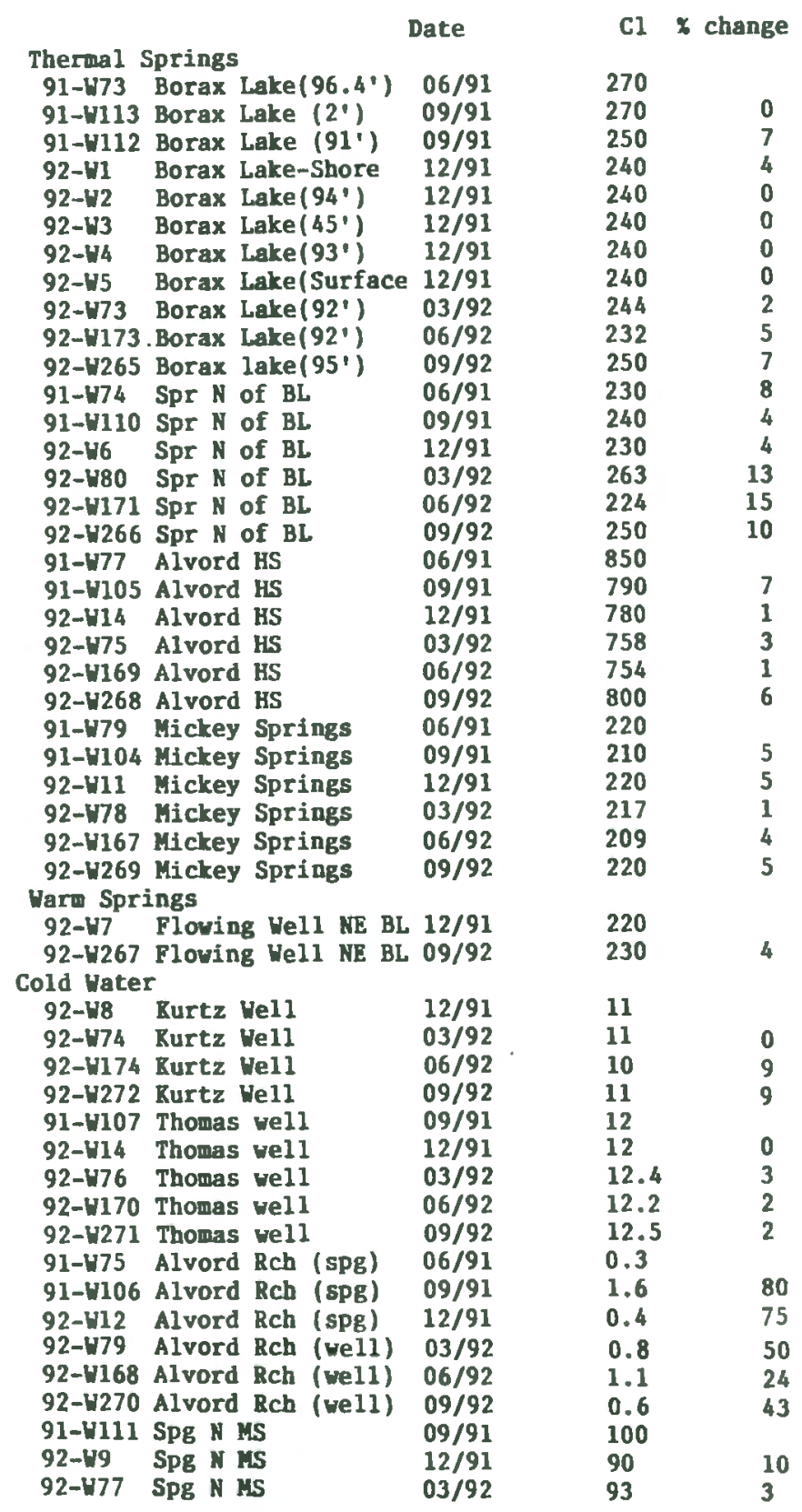




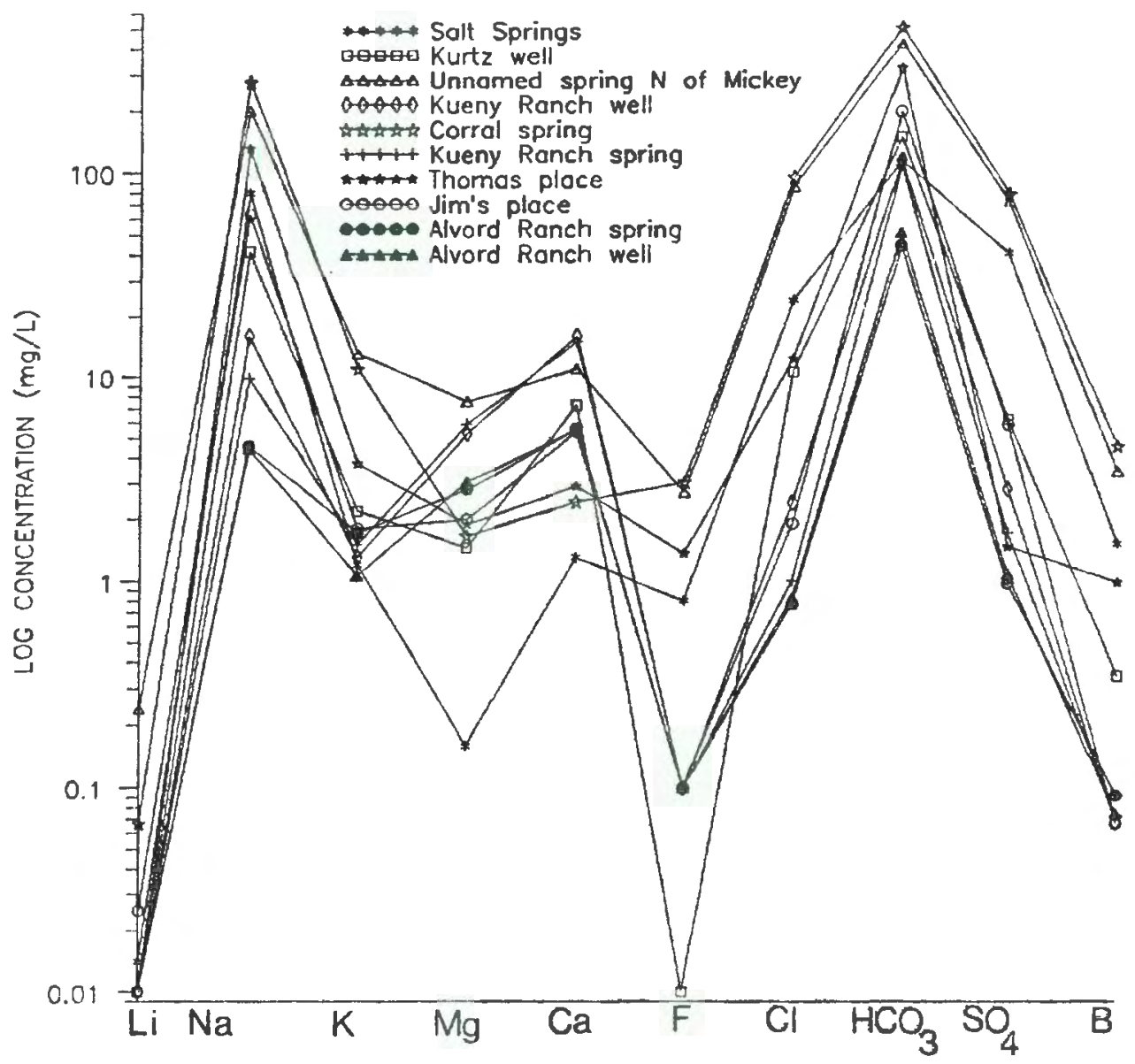

Figure 12. Schoeller diagram for cold water chemistry. 
concentrated in $\mathrm{Na}, \mathrm{Cl}$ and $\mathrm{HCO}_{3}$ than other cold waters. However, it must be noted that the unnamed spring in Mickey Basin is a watering hole for cattle and cattle activities may have led to elevated $\mathrm{Na}, \mathrm{Cl}$ and $\mathrm{HCO}_{3}$ concentrations. Chloride concentrations are also elevated in water from salt springs south of Borax Lake (24 mg/1), Thomas well (12 $12.5 \mathrm{mg} / 1)$, and the Kurtz well (9.9-11 $\mathrm{mg} / 1)$.

Mifflan (1988) notes that groundwater in the Great Basin generally begins as a $\mathrm{CaMgNa}-\mathrm{HCO}_{3}$ type in recharge areas, and its chemistry evolves along the flowpaths as a function of the lithologies encountered. In the Alvord basin, the chemistry of water begins as a dilute $\mathrm{Ca}$ - or Na$\mathrm{HCO}_{3}$ in the Steens Mountain fault block as a function of interaction with the extensive section of Tertiary volcanics (e.g. Alvord Ranch spring and well, spring at Jim's place, Kueny Ranch well and spring and McDade place). Typically, along the longer flowpaths in most types of rocks, including the basin fill, $\mathrm{SO}_{4}$ and $\mathrm{Cl}$ ions tend to increase in relative concentrations (Mifflan, 1988). The Kurtz well, Corral spring and unnamed spring north of Mickey Springs have increased concentrations of $\mathrm{SO}_{4}$ and $\mathrm{Cl}$ relative to other cold springs and wells in the Alvord basin indicating increased fluid-rock interaction and longer flowpaths. Base exchange is common in basin sediments, with $\mathrm{Ca}$ and $\mathrm{Mg}$ concentrations decreasing, and $\mathrm{Na}$ and $\mathrm{K}$ ions increasing along flowpaths (Mifflan, 1988). Sodium and potassium are 
the dominant cations in water from Corral spring, the Thomas well and the unnamed spring north of Mickey Springs indicating increased interaction with basinal sediments.

The hydrogeochemical program PCWATEQ is employed to determine the degree of saturation of cold waters with various mineral phases. Alvord Ranch well and spring waters are oversaturated with respect to silica phases. Kurtz well waters are oversaturated with respect to silica phases and calcite. Thomas place well waters are oversaturated with respect to silica phases, Mg-silicates and calcite (Appendix, Table XV).

Concentrations of trace elements such as Li, Cl, B, and F are determined by the total leachable concentrations of these elements in the rocks through which fluids circulate. Ratios among these elements are usually not affected by dilution and lower temperature reactions (White, 1965; Ellis, 1970; Truesdell, 1976). These elements behave conservatively in mixing and fluid-rock interactions. Thus, $\mathrm{B} / \mathrm{Cl}$ ratios give strong indications of the type of rocks with which the water has equilibrated.

The $\mathrm{B} / \mathrm{Cl}$ ratios for non-thermal waters in the Alvord basin range from 0.01 to 0.43 . Goff el al. (1987) note that ratios of $>0.1$ generally indicate interactions with sedimentary rocks whereas ratios between 0.01 and 0.1 commonly indicate interaction with volcanic rocks. The B/Cl ratios for some of the Alvord basin waters indicate 
interactions with volcanic or volcaniclastic rocks (e.g. Kurtz well, Kueny Ranch, Corral spring and an unnamed spring in Mickey Basin, Scoubes Creek, and Indian Creek). However, other non-thermal waters indicate interaction with sediments or sedimentary rocks (e.g. Alvord Ranch well and Thomas we11).

\section{Chemistry of Thermal Waters}

The chemistry of the thermal water is presented on a Schoeller diagram (Figure 13) in which, for each sample, a line connects points calculated as the $\log _{10}$ of the concentration of each constituent. Where the lines connecting points for two samples are parallel, the constituents have the same ratio in the two samples. While ratios are generally similar for all thermal fluids, differences are apparent for fluids from Alvord Hot Springs. Ratios are nearly identical for Borax Lake, the hot springs north of Borax Lake and the flowing well northeast of Borax Lake; the waters have virtually identical chemical compositions and are clearly derived from the same parent water.

Thermal waters in the Alvord basin are classified as $\mathrm{Na}-\mathrm{HCO}_{3}$ waters with significant amounts of $\mathrm{SO}_{4}$ and $\mathrm{Cl}$. An initial classification of the waters is carried out on the basis of their major anions, $\mathrm{Cl}, \mathrm{SO}_{4}$ and $\mathrm{HCO}_{3}$ (Figure 14). The dominant anion for Mickey Springs fluids is $\mathrm{HCO}_{3}$, therefore, they plot close to the $\mathrm{HCO}_{3}$ corner. Fluids from 

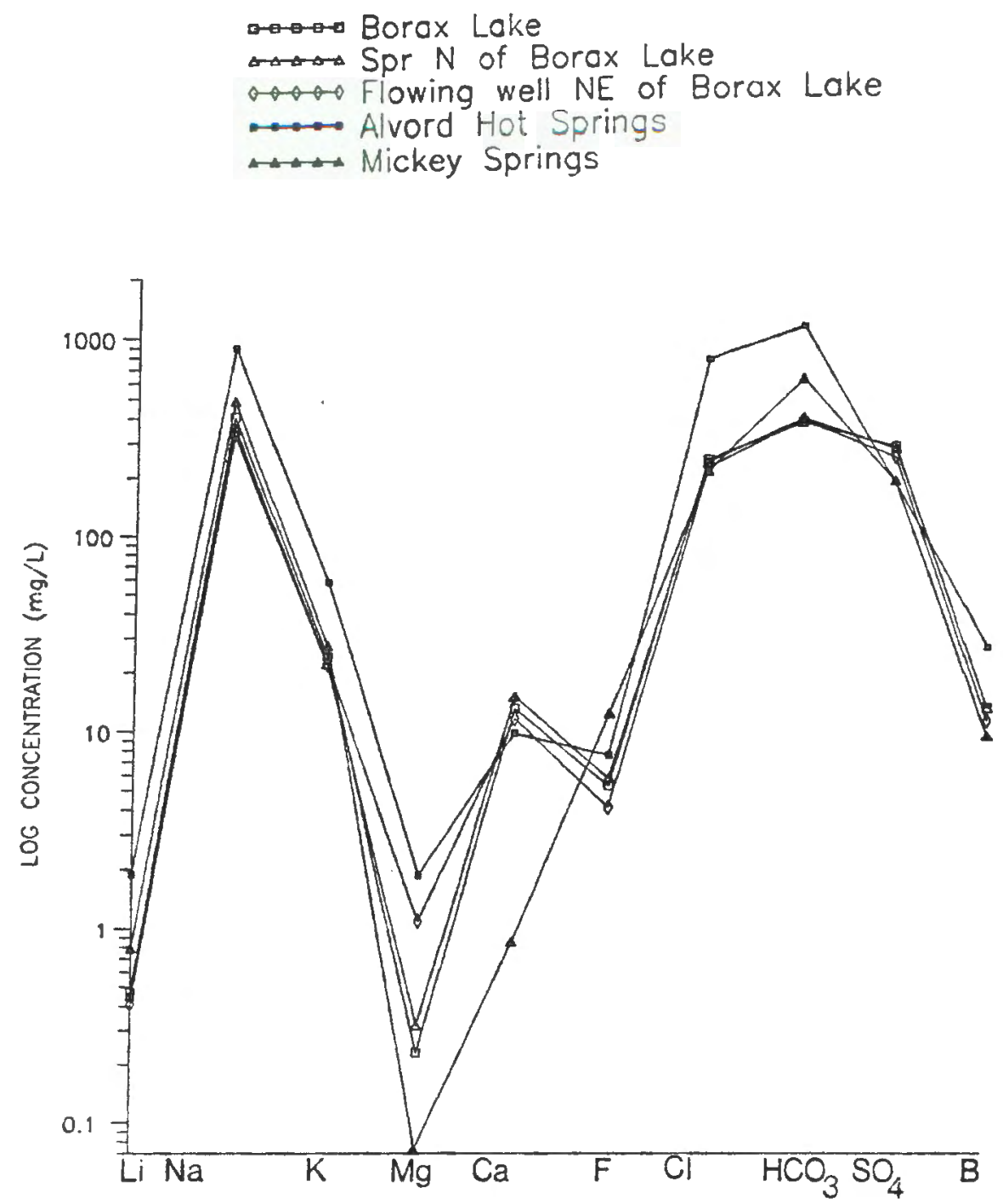

Fiqure 13. Schoeller diagram of thermal water chemistry. 


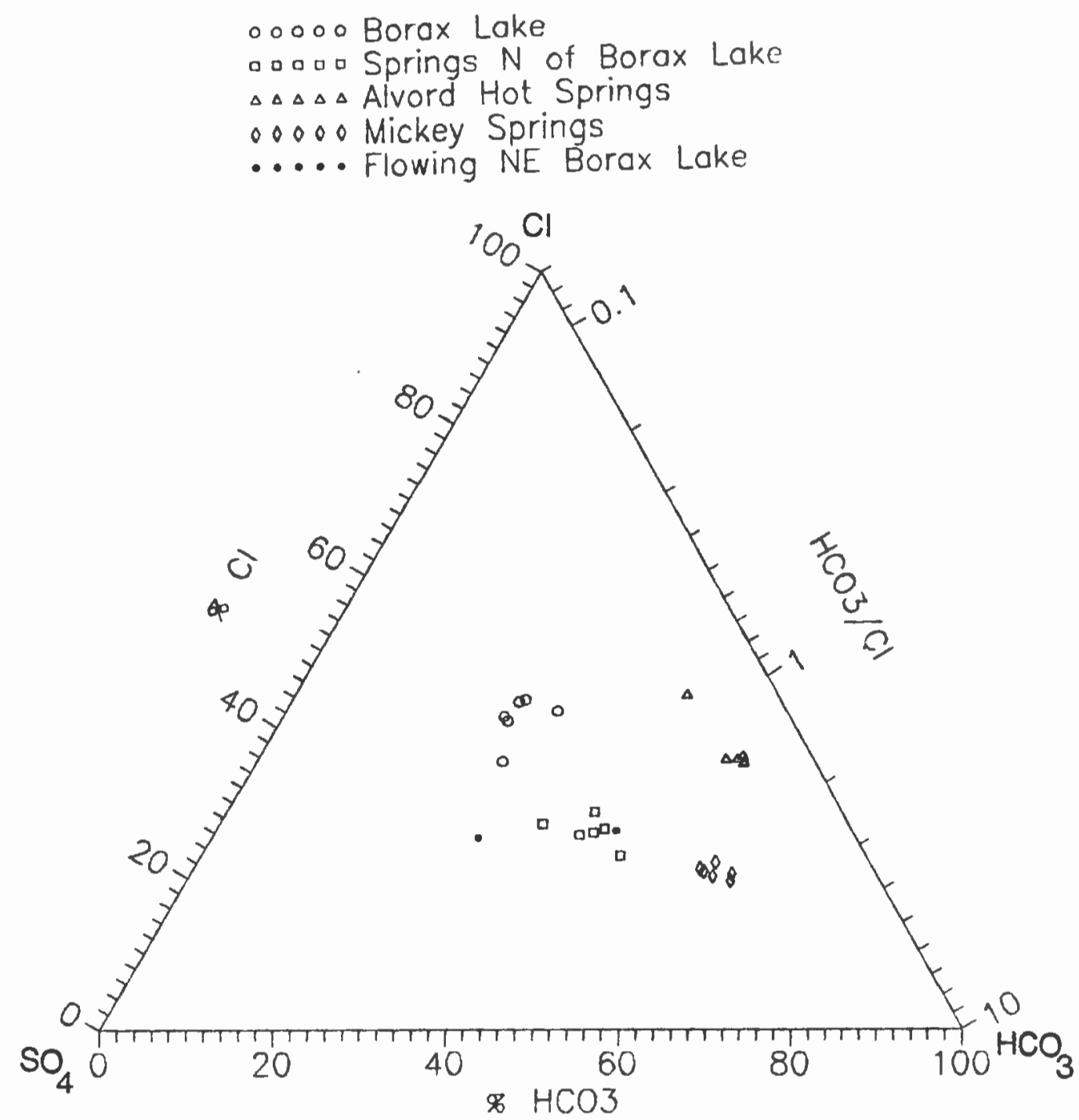

Fiqure 14. Relative $\mathrm{Cl}, \mathrm{SO}_{4}$ and $\mathrm{HCO}_{3}$ contents of thermal fluids on a weight basis $(\mathrm{mg} / \mathrm{kg})$. 
Borax Lake have similar $\mathrm{SO}_{4}, \mathrm{HCO}_{3}$ and $\mathrm{Cl}$ contents and thus plot close to the center of the diagram. While fluids from the springs north of Borax Lake and the flowing well

northeast of Borax Lake are similar to Borax Lake, they contain less $\mathrm{Cl}$. Fluids from Alvord Hot Springs are dominated by $\mathrm{HCO}_{3}$ and $\mathrm{Cl}$ with minor $\mathrm{SO}_{4}$. The most concentrated waters occur at Alvord Hot Springs where the highest concentrations of $\mathrm{Na}, \mathrm{K}, \mathrm{Mg}, \mathrm{HCO}_{3}, \mathrm{Cl}, \mathrm{B}$ and $\mathrm{Li}$ were recorded (Table IV). The composition of thermal waters from Borax Lake, the hot springs north of Borax Lake and the flowing well northeast of Borax Lake is similar; fluids possess nearly identical concentrations of $\mathrm{K}, \mathrm{Ca}, \mathrm{Cl}, \mathrm{SO}_{4}$, $\mathrm{HCO}_{3}, \mathrm{~B}$, and $\mathrm{Li}$. While Mickey Springs waters have the highest concentrations of $F$ and dissolved silica, they contain the lowest concentrations of $\mathrm{Mg}$ and $\mathrm{Ca}$.

Chloride correlates well with Li and B (Figure 15). These correlations could result from either the modification of cold recharge water by fluid-rock interactions at high temperatures, longer flow-paths, boiling and evaporation, or mixing of thermal water with a cold water containing high $\mathrm{Cl}$ and low $F$ and $B$. Small variations in chloride concentrations over time argue against mixing of thermal water with cold water during the sampling period.

The fluoride concentrations vary greatly and are not closely correlated with concentrations of more stable ions such as chloride (Figure 15). Thermal fluids from Alvord 
a... Cold Waters

..... Springs north of Borax Lake

..... Alvord Hot Springs

$\because \ldots$ Mickey Springs
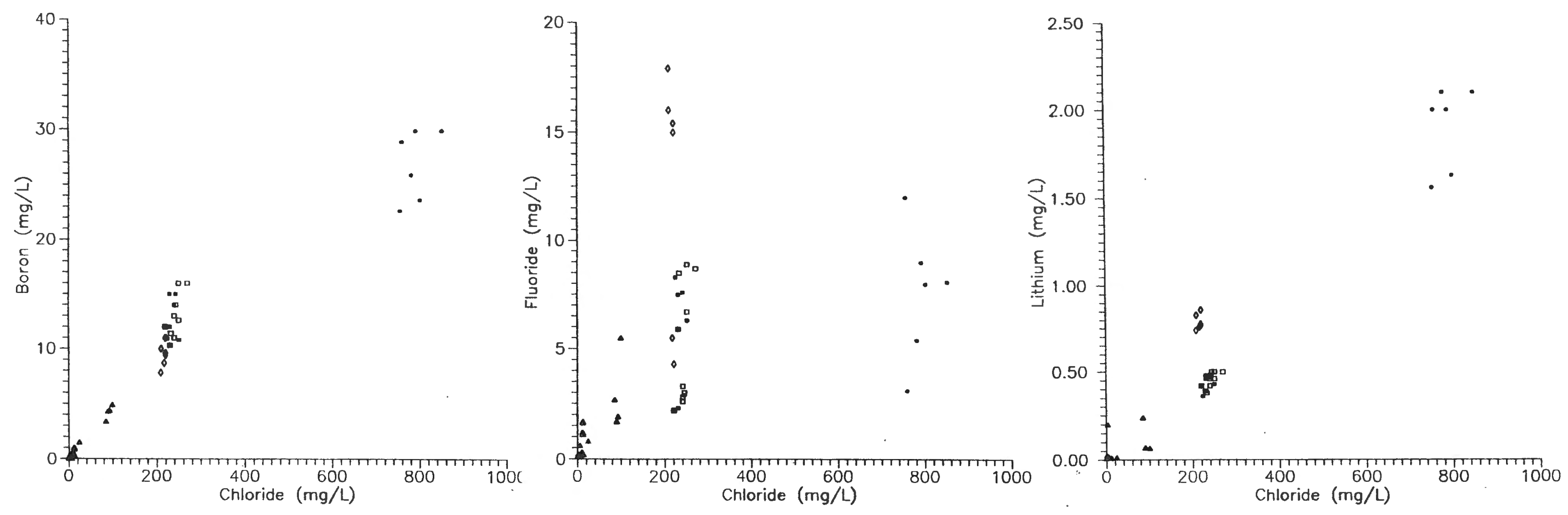

Fiqure 15. Plots of $\mathrm{B}, \mathrm{F}$, and $\mathrm{Li}$ vs. Cl for

thermal and non-thermal waters from Alvord Basin 
Hot Springs possess the highest concentrations of $\mathrm{B}, \mathrm{Cl}, \mathrm{F}$ and $L i$ of all the thermal waters and a linear trend from cold water to Alvord Hot Springs water is observed on all plots.

The thermal springs in the three areas studied possess similar $\mathrm{B} / \mathrm{Cl}$ ratios $(0.03$ to 0.07$)$. The $\mathrm{B} / \mathrm{Cl}$ ratios for the Alvord basin thermal areas are consistent with volcanic or volcaniclastic reservoirs. In addition, the $\mathrm{B} / \mathrm{Cl}$ ratios for Borax Lake, the hot springs north of Borax Lake, and the warm flowing well northeast of Borax Lake are nearly constant at $0.05-0.06$. Constant ratios of conservative elements indicate a common reservoir source for these fluids.

Another conservative element ratio in hydrothermal solutions, Li/Cs, remains close to that of the rock with which the fluid equilibrated. In addition, Li/Cs ratios are a function of rock type. Taylor (1974) notes that this ratio is lower in rhyolitic rocks as compared to basalts. Table XIV contains geochemical data for the Borax Lake thermal area for the period from 1953 to 1989 . Lithium and Cs concentrations are available for Borax Lake and some of the springs north of Borax Lake for this period. Calculated Li/Cs ratios range from 2.5 to 6.5 . These low ratios are similar to ratios for rhyolite or silicic tuff host rocks in other thermal systems in the world (e.g. Wairakei and White Island, New Zealand, Giggenbach and Goguel, 1989b; 
Platanares, Honduras, Goff et al., 1987). These low ratios may indicate that the reservoir source for Borax Lake thermal area fluids is the silicic ignimbrite and rhyolite flows overlying the Steens Basalt or the rhyolite flows and tuffs of the Pike Creek Formation below the Steens Basalt. The program SOLMINEQ.88 (Kharaka et al, 1988) was used to calculate the saturation indices $\left(\log \left(I A P / K_{s p}\right)\right.$ for potential phases present in equilibrium with fluids in the Alvord basin thermal areas. These were calculated at measured temperatures and at chemical and isotopic geothermometer estimates. The calculations using the higher temperatures are believed to more closely approximate conditions in the deep thermal aquifer. Geochemical modeling indicates that thermal fluids are oversaturated with respect to silica phases, $\mathrm{Mg}-\mathrm{silicates}$ and calcite (Appendix, Table XVI).

\section{LIGHT ISOTOPE GEOCHEMISTRY}

Light stable and radioactive isotopes provide information on the history and recharge of geothermal fluids and cold surface and ground water sources. The isotopes of $O$, $H$, and $C$ were determined for fluids in this study.

\section{Oxygen and Deuterium}

Stable isotopes of water $\left(\mathrm{D}, \mathrm{H},{ }^{16} \mathrm{O}\right.$, and $\left.{ }^{18} \mathrm{O}\right)$ are used to identify recharge areas of geothermal systems and subsurface processes such as mixing and boiling in 
geothermal reservoirs (Craig, 1961; Craig et al., 1956; Taylor, 1974; Truesdell and Hulston, 1980; Fournier and Hanshaw, 1986; Taylor and Stewart, 1987; Parry and Bowman, 1990; Sorey et al., 1991). Thus, the recharge area of deeply circulating ground water may be indicated by a comparison of its isotopic composition with that of shallow ground water and directly collected precipitation from potential recharge areas.

The ${ }^{18} \mathrm{O} /{ }^{16} \mathrm{O}$ ratio of the water is subject to alteration by exchange with solid phases at high temperatures as determined by the ${ }^{18} \mathrm{O} /{ }^{16} \mathrm{O}$ of exchangeable mineral oxygen, the rate and temperature of exchange, and fluid:rock mass ratio considerations. The $\mathrm{D} / \mathrm{H}$ ratio does not change as readily because most minerals do not contain hydrogen and thus records the source of the water more reliably. For example, in meteoric- and seawater-hydrothermal systems, the $6 \mathrm{D}$ values are often constant in spite of extensive mineralwater reactions, while the oxygen isotope composition undergoes an "10-shift" away from its initial value (Sheppard, 1986). In geothermal systems with a meteoric component, the $\delta \mathrm{D}$ values are similar to cold ground water and springs and the $\delta^{18} \mathrm{O}$ values are enriched, reflecting fluid-rock interactions at elevated temperatures.

Normal meteoological and topographic effects cause variations in stable isotopes (Fontes, 1980). Isotopic values vary with latitude, wind patterns, distance inland 
from the ocean, and elevation. Figure 16 iliustrates this variation by showing contours of the approximate average $6 \mathrm{D}-$ values of meteoric waters for North America (Taylor, 1974).

The Alvord basin is located in the rain shadow of the Steens Mountain-Pueblo Mountajns escarpment. The amount of local precipitation is strongly affected by the prevailing weather patterns. Prevailing weather patterns in the winter, when most precipitation occurs, often bring moisture from across northern California and over the steen MountainPueblo Mountains escarpment.

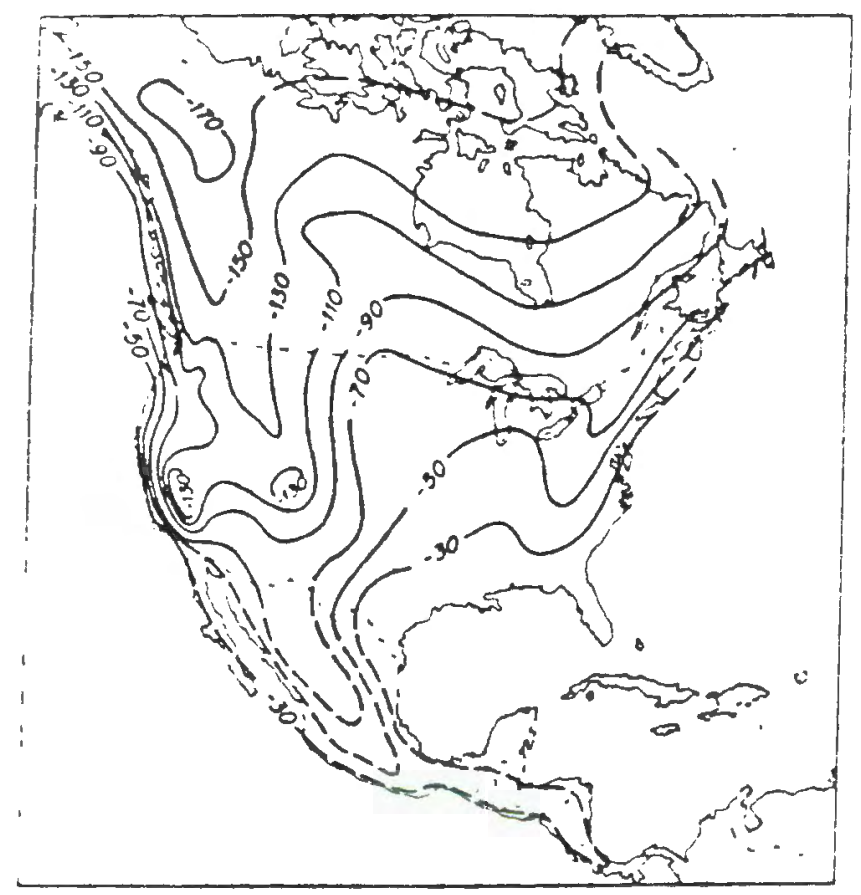

Figure 16. Map of North America showing contours of the approximate $6 \mathrm{D}$ values of meteoric surface waters (Taylor, 1974). 
Thirty water samples were collected for $\delta \mathrm{D}$ and $\delta^{18} \mathrm{O}$ isotopic analyses in the Alvord basin (Table VI) in order to determine recharge to the thermal areas and the seasonal variations in water isotope values.

Surface and Groundwater. Shallow and locally derived ground water, cold springs, and streams are used to characterize the average isotopic composition of local meteoric water in the Alvord basin. The $\delta D$ and $\delta^{18} O$ values for cold surface and ground water are presented in Table VI and plotted in Figures 17 and 18. Cold springs, wells and streams plot on or close to the world meteoric line (Figure 17). Local recharge water has an $\delta^{18} \mathrm{O}$ value about $0.5 \%$ heavier than the world meteoric water line. Sheppard (1986) notes that meteoric waters that have not experienced extensive evaporation plot within a band up to $\pm 1 \%$. $\delta^{10} \mathrm{O}$ of the meteoric water line. The $\delta D$ values for local recharge waters vary between $-131 \%$ and $-107 \%$ and the $\delta^{18} \mathrm{O}$ values between $-17.9 \%$ and $-15.1 \%$. A snow sample collected on the west slope of Steens Mountain has the lowest deuterium content. This sample was collected at an elevation of approximately $2408 \mathrm{~m}$. The low deuterium content implies the water originated at a higher elevation than fluids from the Alvord basin. The isotopically heaviest sample was collected during a small rain storm (December, 1991) on the floor of the Alvord basin. The isotopic value is heavier than any other sample collected in 
this study and may represent evaporation during descent. The water from the Thomas well has the lowest deuterium content of all cold water samples collected in the Alvord basin. The low deuterium content indicates that water originated at a higher elevation on Steens Mountain than water from other sites. Assuming an isotopic gradient of ${ }^{18} \mathrm{O}$ of $0.30 / 00 / 100 \mathrm{~m}$ (Fontes, 1980), Thomas well water was generated at an elevation of approximately 7300 feet. In contrast, Alvord Ranch well water has the highest deuterium content, possibly suggesting recharge from a lower elevation. The range of isotopic composition for cold waters may reflect the differences in elevation where water released from snow melt and rainfall enter the ground water system or mixing relations among water of diverse, but of a relatively narrow isotopic range.

Pore fluids from cores taken from Alvord Lake (Matthews, written communication, May, 1992) become more depleted in both $\delta^{18} \mathrm{O}$ and $\delta \mathrm{D}$ with depth. The $\delta \mathrm{D}$ values of pore fluids at depths from 4 to $5 \mathrm{~m}$ are similar to $\delta \mathrm{D}$ values for local recharge (Table VI, Core 89-1). Isotopic enrichment in fluids from depths less than $4 \mathrm{~m}$ suggest evaporative concentration and fluid-sediment interactions typical of closed basin pore fluid evolution (Eugster and Jones, 1979). In addition, the slope of the best-fit line for the range of isotopic compositions for these samples is approximately 2 to 3 . Sheppard (1986) notes that 
TABLE VI

STABLE-ISOTOPE COMPOSITION OF THERMAL AND NON-THERMAL WATER IN IBE ALYORD BASIN

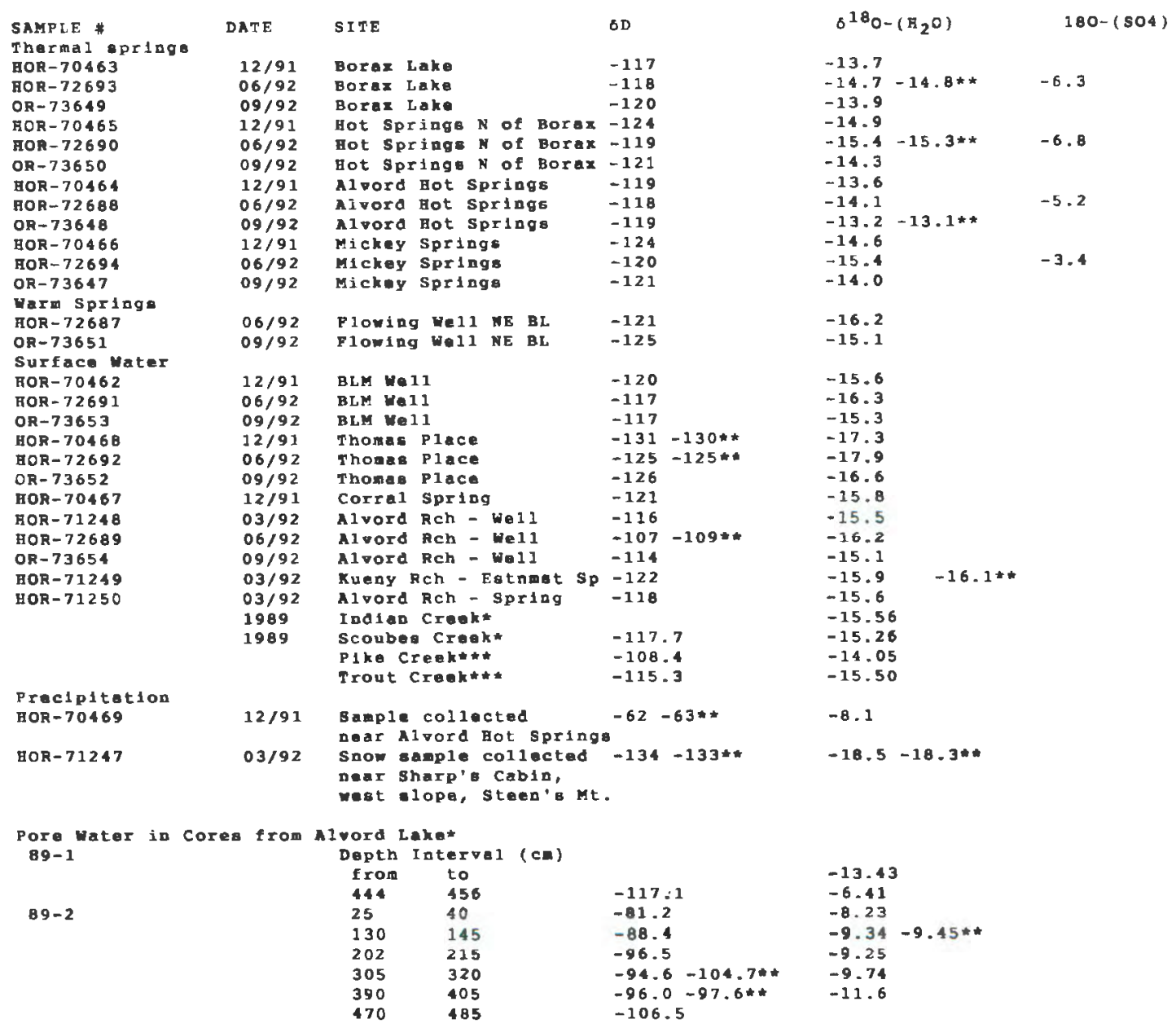

- Analyaes fron Jay Matthews, Department of Geology, Univeraity of I111nois at Urbana-Champajgn * Duplicate preparation and analyoes.

* From Marioer at al.. 1983. 


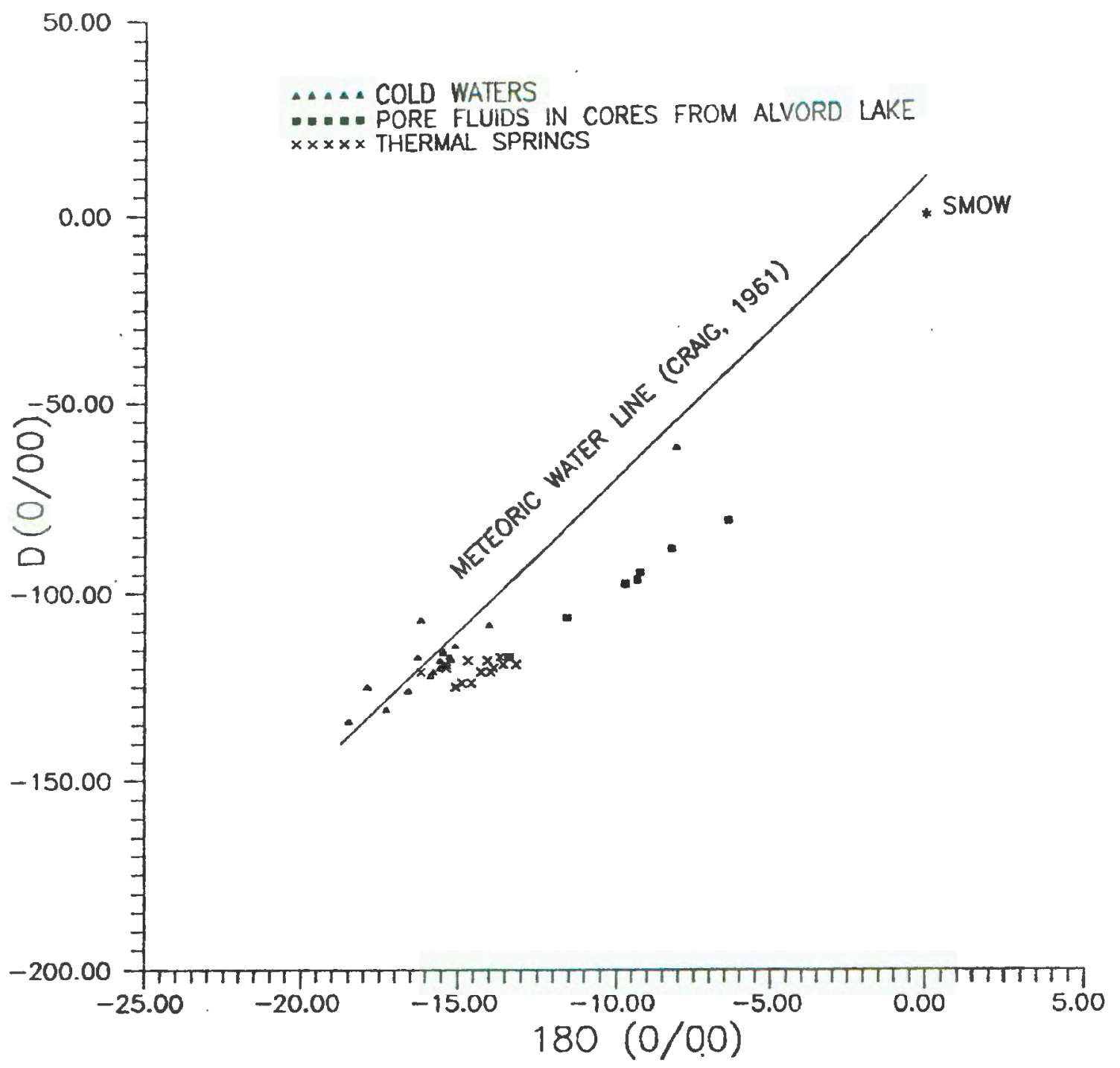

Fiqure 17. Plot of $\delta \mathrm{D}$ vs. $\delta^{10} \mathrm{O}$ showing thermal and cold waters relative to WMWL (World Meteoric Water Line) and SMOW (Standard Mean Ocean Water). 
evaporative waters typically plot about a line with a slope of three.

Variations exist between isotopic values obtained during the winter months and those obtained during the summer months for cold surface and ground water. Figure 18 depicts seasonal isotopic variations for the cold waters from the Alvord basin. The Thomas well is consistently the most depleted isotopically while the Alvord Ranch well is the most enriched. The lowest $\delta^{10} 0$ values for all samples occur in June. In December, cold water samples show relatively increased $\delta^{18} O$ and decreased $\delta D$. In September, cold water samples are relatively enriched in both $\delta D$ and $\delta^{18} \mathrm{O}$.

It must be noted, however, that some of these variations in isotopic composition may be attributed to experimental error. Typical error bars for $\delta \mathrm{D}$ are $\pm 1-2$ and $\delta^{18} 0$ are $\pm 0.1-0.2$.

Geothermal Fluids. The $\delta D$ and $\delta^{18} O$ values for geothermal fluids from hot springs are listed in Table VI and plotted in Figure 17 and 19. The geothermal fluids plot to the right of the world meteoric water line. Thermal waters exhibit an approximate $2 \%{ }^{18} \mathrm{O}$ enrichment. The values for $\delta \mathrm{D}$ and $\delta^{18} \mathrm{O}$ vary between $-124 \%$ and $-118 \%$, and $-15.4 \%$ and $-13.6 \%$, respectively. Similar isotopic composition is apparent between coldand hot-water samples (Figure 17). The flowing well 
northeast of Borax Lake does not exhibit an $\delta^{18} O$ shift, butplots near the world meteoric water line and in the cluster of points for cold water samples. Water from the flowing well northeast of Borax Lake appears to be heated local meteoric water that has not undergone extensive fluidrockinteractions. The thermal springs plot in a cluster within the same range of $\delta D$ values as the cold surface and and ground water. The $\delta \mathrm{D}$ values of Borax Lake $(-117 \%$ and $-118 \%$ ) correspond very closely to the Kurtz well $(-120$ $\%$ and $-117 \%$ ) and Scoubes Creek $(-118 \%$ (Table VI). Likewise, the $\delta \mathrm{D}$ values of Alvord Hot Springs $(-119 \%$ and $-118 \%$ ) correspond closely with the Alvord Ranch well $(-116 \%)$ and Alvord Ranch spring $(-118 \%)$. These similarities indicate that recharge for thermal waters is meteoric; the same fluid source recharges cold surface, ground water, and thermal springs in the Alvord basin.

Seasonal variations are apparent in the isotopic composition of thermal springs (Figure 19). Patterns of enrichment and depletion are similar for some thermal springs and cold surface and ground waters possibly reflecting shallow mixing processes. In general, thermal springs are the most depleted in $\delta^{18} \mathrm{O}$ in June and the most enriched in $6^{18} \mathrm{O}$ in September. While Mickey Springs and the springs north of Borax Lake exhibit similar seasonal isotopic enrichment and depletion trends to cold waters, Alvord Hot Springs and Borax Lake are different. Although 


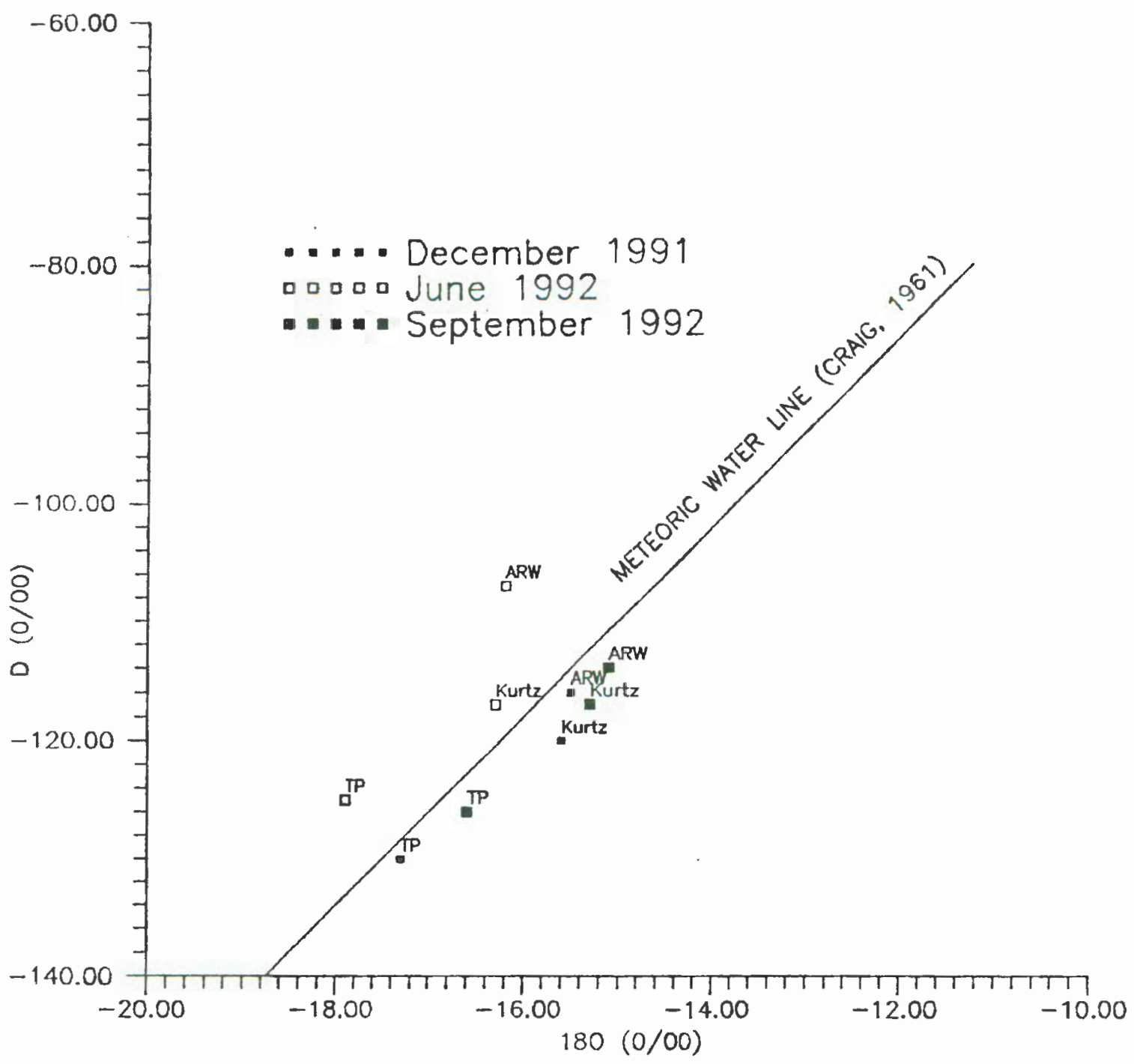

Fiqure 18. Seasonal variations in $\delta \mathrm{D}$ and $\delta^{18} \mathrm{O}$ contents for cold waters. 


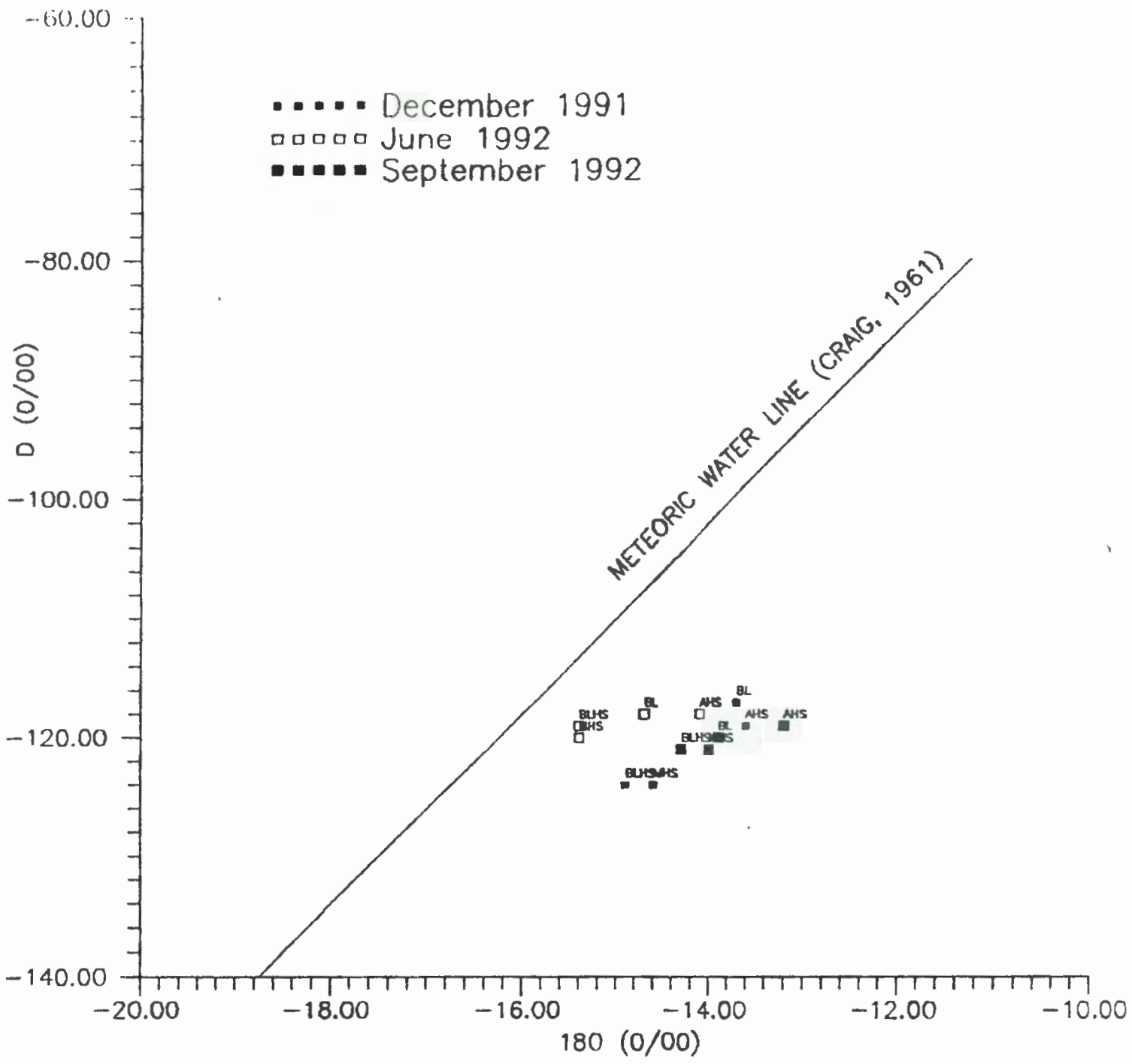

Fiqure 19. Seasonal variations in $\delta D$ and $\delta^{18} O$ contents of thermal waters. 
Alvord Hot Springs is most enriched in $6^{10} \mathrm{O}$ in September, the $\delta D$ content of fluids is relatively constant over time. Mickey Springs and the springs north of Borax Lake are more enriched in $\delta D$ values in September and June than in December (Table VI and Figure 19). Borax Lake and the flowing well northeast of Borax Lake, on the other hand, are more depleted in $\delta D$ values in September than in June or December.

\section{Tritium}

Tritium, a radioactive isotope of hydrogen, is useful in determining the average age of ground water because it has a half-life of 12.43 years and was produced in large quantities during the atmospheric nuclear tests of the 1950 s and early 1960s (Fontes, 1980). As a result of these tests, peak levels of atmospheric tritium occurred in 1963, and levels have been decreasing steadily since that time. Several surface and groundwater systems have been investigated with the use of ${ }^{3} \mathrm{H}$ (Yellowstone National Park by Pearson and Truesdell, 1978; Valles Caldera by Vuataz and Goff, 1986; Platanares, Honduras by Goff et al., 1987; and Mount St. Helens by Shevene11, 1990,1991). Tritiun levels vary greatly by latitude; for example, in 1963 atmospheric tritium in the southwestern United States averaged 2,800 tritium units (T.U.) (Vuataz and Goff, 1986), whereas in Portland, Oregon, it reached only 1,036 tritium units (T.U.) (Michael, 1989). In addition, tritium levels vary seasonally, with maximum values occurring during the summer 
months.

In order to estimate the ages of geothermal systems operating in the Alvord basin, the type of fluid mixing must be evaluated. The ${ }^{3} \mathrm{H}$ model to be discussed involves a procedure whereby Iimits are placed on groundwater mean residence times by calculating two end-member cases with known ${ }^{3} \mathrm{H}$ input to the system. According to Pearson and Truesdell (1978), two end-member models may be used to place limits on the mean residence time for groundwater: piston flow and perfect mixing.

The piston-flow model yields the lower limit on fluid age. This model assumes that there is no mixing of the water in the reservoir from the time of recharge to the time of discharge. Thus, all molecules have the same residence time and travel through the system from recharge to discharge without being mixed with molecules from other sources. The output tritium level depends upon the residence time and upon tritium concentration in the recharge. The equation describing this model is

$$
C_{\text {out }}(t)=C_{1=}(t-\tau) e^{-2 t},
$$

where $C_{\text {out }}(t)$ is the tritium level in the discharge fluid at time $t, c_{1 n}(t-\tau)$ is the tritium level in the recharge fluid at the time of recharge, $\tau$ is the residence time, and $\lambda$ is the decay constant for tritium $\left(5.576 \times 10^{-2} \mathrm{yr}^{-1}\right)$.

Because the piston-flow model does not account for mixing (or dispersion), nor does it account for the 
possibility that the system may have many points of input, the well-mixed model is used to calculate an upper limit of the average age of the fluid in a system. The perfectmixing model (or well-mixed model) assumes that, each year, fluid is recharged to the aquifer and all recharged water is completely mixed with fluid already in the reservoir. Hence, fluid discharging from the system has the same composition as the mixed fluid within the reservoir. The equation that describes the perfect-mixing model is

$$
\frac{d c(t)}{d t}=\left(q_{1 n} / V\right) C_{1 n}(t)-\left(q_{\text {out }} / V\right) c(t)-\lambda c(t),
$$

where $c(t)$ is the tritium level in the reservoir (and the discharge) at time $t, q_{1 \mathrm{n}}$ and $\mathrm{g}_{\text {out }}$ are the recharge and discharge flow rates, and $V$ is the fluid volume in the reservoir. In the absence of information about the rates ofrecharge and discharge over time, it is assumed that $q_{i n}=$ $\mathrm{q}_{\text {out }}=$ constant and that $\mathrm{V}=$ constant. The above equation can be rearranged to give

$$
\frac{d C(t)}{d t}+\frac{1}{\tau}+\lambda C(t)=\frac{1}{\tau} C_{i n}(t),
$$

where $\tau$ is defined as $V / q$, the mean residence time. The solution to this equation is

$$
C(t)=e^{-(1 / \tau+2) t}\left\{1 / \tau \int_{0}^{t} C_{1 n}(t) e^{(1 / \tau+2) t} d t+K\right\} \text {, }
$$

where $k$ is the constant of integration. This constant is to be evaluated at the initial condition $C(0)=C_{0}$ and is the original tritium concentration in the reservoir before nuclear testing began. It is assumed that $C_{0}=0$ because 
the natural production of tritium before nuclear testing approaches zero. It is important to note that the wellmixed model yields excessive ages if the system has an appreciable piston-flow component (Shevenel1, 1990).

During this study, nine samples from cold and hot springs, flowing streams and wells were analyzed for tritium (Table VII). Because samples for tritium were collected at one point in time, they cannot be used to determine the exact ages of fluids, but they do provide a basis for estimating relative times of residence in aquifers.

Because Portland, Oregon is the station closest to the Alvord basin, ${ }^{3} \mathrm{H}$ data from precipitation at Portland is used to estimate $C_{1 n}$ for the ${ }^{3} \mathrm{H}$ models. Shevenell (1990) generates input functions for the above equations using estimated and developed ${ }^{3} \mathrm{H}$ data for Portland, Oregon for the years 1952 to 1983 (Table VIII) in order to estimate mean residence times for fluids in the hydrothermal system at Mount st. Helens.

While yearly tritium data is unavailable for the Alvord basin region, general estimates of tritium contents of precipitation for southeastern Oregon have been made. Sammel and Craig (1981) cite tritium level estimates for the Warner Valley, located approximately $100 \mathrm{~km}$ west, at the same latitude but $1^{\circ} 30^{\prime}$ longitude west of the Alvord basin, and in a similar climatic setting. They note that tritium 
TABLE VII

TRITIUM CONCENTRATIONS AND ESTIMATED MEAN RESIDENCE TIMES FOR THERMAL SPRINGS AND COLD WATER WELLS AND SPRINGS IN THE ALVORD BASIN

\begin{tabular}{|c|c|c|c|c|c|}
\hline $\begin{array}{l}\text { Location } \\
\text { Thermal } \\
\text { Springs }\end{array}$ & Date & $\begin{array}{l}\text { Tritium } \\
(\text { T.U. })^{\star}\end{array}$ & Error(eTU) & $\begin{array}{l}\text { Piston Flow } \\
\text { Age (years) }\end{array}$ & $\begin{array}{l}\text { Well Nixe } \\
\text { Age (year }\end{array}$ \\
\hline Borax Lake & $8 / 26 / 92$ & 0.25 & 0.09 & 57 & 3,394 \\
\hline $\begin{array}{l}\text { Hot springs } \\
\mathrm{N} \text { of } \mathrm{BL}\end{array}$ & $8 / 26 / 92$ & 0.15 & 0.09 & 70 & 7,100 \\
\hline $\begin{array}{l}\text { Flowing we11 } \\
\text { NE of } B L\end{array}$ & $8 / 26 / 92$ & -0.01 & 0.09 & $>156$ & $>10,000$ \\
\hline $\begin{array}{l}\text { Alvord Hot } \\
\text { Springs }\end{array}$ & $9 / 3 / 92$ & 0.14 & 0.10 & 67 & 6,082 \\
\hline $\begin{array}{l}\text { Mickey } \\
\text { Springs }\end{array}$ & $9 / 3 / 92$ & 0.10 & 0.09 & 73 & 8,525 \\
\hline Cold Waters & & & & & \\
\hline BLM Well & $8 / 26 / 92$ & 0.04 & 0.09 & 89 & $>10,000$ \\
\hline Thomas Place & $9 / 3 / 92$ & -0.03 & 0.10 & $>156$ & $>10,000$ \\
\hline Alvord Ranch & $9 / 3 / 92$ & 10.1 & 0.30 & 16 & 52 \\
\hline Pike Creek & $11 / 2 / 92$ & 7.50 & 0.27 & 12 & 8,83 \\
\hline
\end{tabular}

* TU indicates $7.088 \mathrm{dpm} / \mathrm{kg}$ of water and $3.193 \mathrm{pCi} / \mathrm{kg}$ of water. 
levels in the Warner Valley prior to 1953 were probably about 9 T.U. (vs. 6 T.U. for Portland, Oregon, Table VIII). In addition, tritium levels peaked in 1966 at about 1000 T.U. (vs. 210.3 T.U. for Portland, Oregon, Table VIII) and have declined since then to about 20 T.U. in 1976 (vs. 21.5 for Portland, Oregon, Table VIII). Hence, estimates made by Shevenell (1990) for Portland, Oregon are in general agreement with estimates cited by Sammel and Craig (1981) for the warner Valley located in southeastern Oregon.

Input functions generated by Shevenell (1990) are applied to spring discharges in the Alvord basin in order to predict residence times of fluids collected in 1992. The results of these models are illustrated in Figure 20. Maximum and minimum ages of Alvord basin fluids are extrapolated from the curves given the observed ${ }^{3} \mathrm{H}$ concentrations. Table VII lists tritium data for samples collected at three thermal areas and four cold water springs and wells in the Alvord basin.

Applying these models to the Alvord basin, the low measured ${ }^{3} \mathrm{H}$ concentrations in thermal springs $(-0.01 \pm 0.09$ to $0.25 \pm 0.09$ T.U.) suggest that reservoir fluids are old. Table 20 summarizes mean residence times for Alvord basin fluids. These models generate a range of mean residence times for thermal fluids between 57 and 73 years (piston) and 3,400 to greater than 10,000 years (well- 
WEIGHTED MEAN TRITIUM VALUES FROM PRECIPITATION

IN SELECTED AREAS OF THE WESTERN UNITED STATES

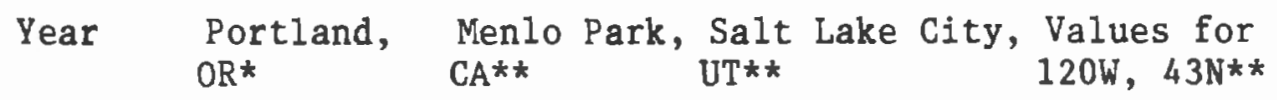

\begin{tabular}{|c|c|c|c|c|}
\hline 1952 & 6 & & & \\
\hline 1953 & 7 & 15 & 8.4 & \\
\hline 1954 & 103 & 45 & 117 & \\
\hline 1955 & 15 & 26 & 16 & \\
\hline 1956 & 63 & 34 & 74 & \\
\hline 1957 & 38 & 40 & 69 & \\
\hline 1958 & 229 & 102 & 316 & \\
\hline 1959 & 171 & 105 & 206 & \\
\hline 1960 & 52 & 27 & 62 & \\
\hline 1961 & 79 & 13 & 87 & \\
\hline 1962 & 411 & 106 & 493 & \\
\hline 1963 & 1209.5 & 211 & 1281 & \\
\hline 1964 & 490 & 123 & 1158 & 430 \\
\hline 1965 & 288.8 & 62 & 452 & 130 \\
\hline 1966 & 201.3 & 34 & 137 & 62 \\
\hline 1967 & 122 & 48 & 195 & 63 \\
\hline 1968 & 83.7 & 18 & 168 & 55 \\
\hline 1969 & 95.5 & 35 & 110 & 44 \\
\hline 1970 & 68.1 & 35 & 118 & 49 \\
\hline 1971 & 57.4 & 38 & 96 & 31.1 \\
\hline 1972 & 39.7 & 13 & 33 & 14.3 \\
\hline 1973 & 33.2 & 19 & 41 & 15.9 \\
\hline 1974 & 39.9 & 12 & 36 & 10.9 \\
\hline 1975 & 23.4 & 13 & 40 & 21.6 \\
\hline 1976 & 21.5 & 20 & 18 & 5.0 \\
\hline 1977 & 26.6 & 20 & 34 & 8.6 \\
\hline 1978 & 33.5 & 72 & 44 & 17.5 \\
\hline 1979 & 17.9 & 27 & 15 & 11.4 \\
\hline 1980 & 14.4 & 17 & 14 & 9.9 \\
\hline 1981 & 15.2 & 9.5 & 19 & 9.6 \\
\hline 1982 & 7.15 & 11 & 13 & 6.8 \\
\hline 1983 & 8.2 & 9.4 & 11 & 6.5 \\
\hline
\end{tabular}

*Data cited in Shevenell (1990).

Data from Michael (1989).

$\%$ of ppt $=\#$ of months/year T.U. data collected / 12 months $\times 100$ Latitude and Longitude values are similar to Alvord basin. 
mixed). The slightly higher tritium content for Borax Lake suggests that thermal water is mixed with a slightly higher proportion of young recharge, possibly in the form of precipitation into the lake, than the other thermal springs. Tritium concentrations in cold waters are variable. The Kurtz well and the Thomas well have low measured ${ }^{3} \mathrm{H}$ concentrations $(0.04 \pm 0.09$ and $-0.03 \pm 0.10$ T.U., respectively). These values are lower than tritium values obtained for thermal fluids. The ${ }^{3} \mathrm{H}$ models generate mean residence times of 89 and greater than 156 years (piston) and greater than 10,000 years (well-mixed).

In contrast, Pike Creek and the Alvord Ranch well have higher measured ${ }^{3} \mathrm{H}$ concentrations $(7.50$ and $10.1 \pm .30 \mathrm{~T} . \mathrm{U} .$, respectively) than other cold waters. These values are higher than the weighted mean concentrations obtained for precipitation from Portland, Oregon in 1990 (4.5 T.U., Table VIII). The ${ }^{3} \mathrm{H}$ models generate mean residence times of 12 and 16 years (piston) and 8,52 and 83 years (well-mixed). Tritiur levels for Pike Creek and the Alvord Ranch well suggest that these sites are recharged by snowmelt and runoff from Steens Mountain generated during the previous summer months. Hence, tritium values and modeling indicate the presence of two types of cold meteoric water in the Alvord basin - an older, poorly mixed, more saline fluid found in artesian wells and springs located in basinal sediments and a younger, more dilute, well-mixed fluid found 


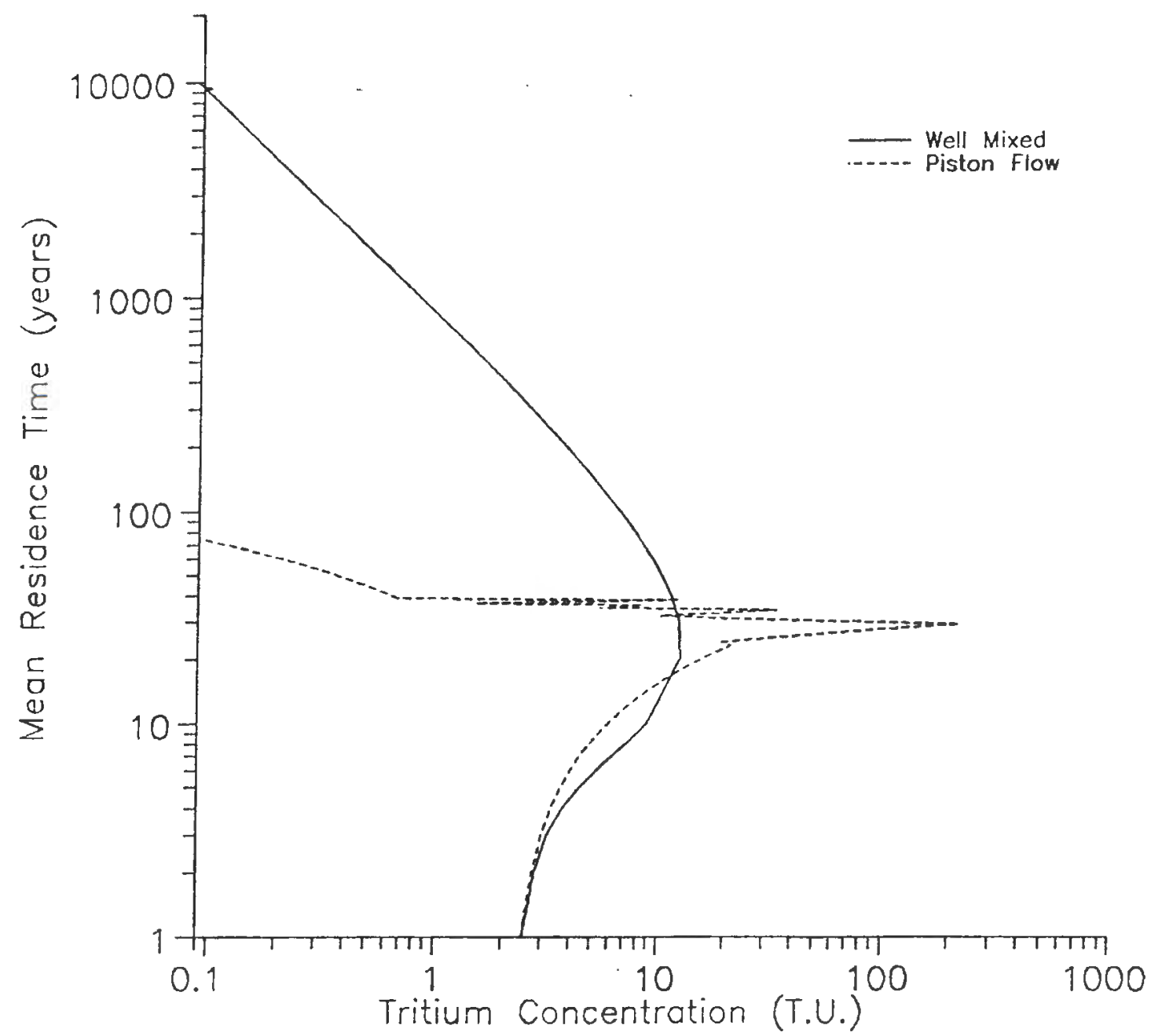

Figure 20. Tritium models for Alvord basin cold and thermal waters. 
in shallow wells located in alluvial fan gravels and in streams flowing off the eastern slope of the Steens Mountain escarpment.

Uncertainty in estimated fluid residence time introduced by an analytical error of \pm 0.1 T.U. for systems with low ${ }^{3} \mathrm{H}$ concentrations such as occur in the Alvord basin can be dramatic. A measured ${ }^{3} \mathrm{H}$ content of $0.14 \pm 0.10 \mathrm{~T} . \mathrm{U}$. yields large variations in fluid ages (i.e. for the wellmixed model, 3600-10,000 years). At higher ${ }^{3} \mathrm{H}$ concentrations, the errors in fluid ages are much smaller. For example, a fluid with a ${ }^{3} \mathrm{H}$ content of $10.1 \pm 0.30 \mathrm{~T} . \mathrm{U}$. yields a well-mixed age of 52 years \pm 3 years. Therefore, the estimated mean residence times provide upper and lower age limits only.

Uncertainty in the residence time may be reduced if the mixing characteristics of fluids in the reservoir are known. However, the hydrology within the Alvord basin and of the geothermal systems is poorly known. Whether the fluid systems are well-mixed or have a significant piston-flow component can be evaluated by repeated sampling over a period of years. Presently, the tritium measurements reported herein are the only data set from which to evaluate residence times. 


\section{CHEMISTRY OF GAS DISCHARGES}

As thermal fluids boil, they generate gas phases. Chemically inert, non-reactive constituents in these gas discharges may serve as tracers; these include $\mathrm{He}, \mathrm{Ar}$ and $\mathbb{N}_{2}$. These constituents remain unchanged once added to fluids and gases allowing their origins to be traced back to their sources. Ratios of various chemical constituents in gases allow further analysis and identification of different source components, residence times or processes not elucidated by fluid chemistry for Alvord basin thermal areas.

Gas samples were collected at the springs north of Borax Lake, Alvord Hot Springs and Mickey Springs. Logistical problems prevented gas sampling at Borax Lake. The gas geochemistry of the Alvord basin thermal areas has not been previously studied. Table IX summarizes the composition of gas discharges collected at the three thermal areas.

Variations in gas geochemistry exist among the three sites. Alvord Hot Springs has the highest concentration of all gas constituents. Carbon dioxide is the dominant constituent in gases from Alvord Hot Springs and Borax Lake, while water is the dominant constituent in a fumarole sampled at Mickey Springs. Ellis (1979) notes that the tendency to precipitate calcite in natural upflow channels is particularly marked for gases and waters containg high 
$\mathrm{CO}_{2}$ concentrations. The high concentrations of $\mathrm{CO}_{2}$ in gases from the springs north of Borax Lake, geochemical modelling (Appendix, Table XVI) and the precipitation of small amounts of calcite at the surface suggest calcite precipitation in upflow zones.

Oxygen is present and sulfur is absent in the geothermal gases. The presence of oxygen and the absence of $\mathrm{H}_{2} \mathrm{~S}$ indicates relatively oxidizing conditions in upflow zones, and, possibly the reservoir. The following reactions may apply to such an environment:

$$
\begin{aligned}
& \mathrm{FeS}_{2}+\mathrm{O}_{2} \rightarrow \mathrm{Fe}(\mathrm{OH})_{3}+\mathrm{SO}_{4}{ }^{2-}, \\
& \mathrm{H}_{2} \mathrm{~S}+4 \mathrm{H}_{2} \mathrm{O} \rightarrow \mathrm{SO}_{4-2}+10 \mathrm{H}^{+}, \\
& \mathrm{CH}_{4}+2 \mathrm{H}_{2} \mathrm{O} \rightarrow \mathrm{CO}_{2}+8 \mathrm{H}^{+}
\end{aligned}
$$

Figure 21 shows the relative contents of $\mathrm{CH}_{4}, \mathrm{CO}_{2}$ and $\mathrm{N}_{2}$. $\mathrm{CH}_{4}$ contents are low relative to $\mathrm{N}_{2}$ and $\mathrm{CO}_{2}$. Gas discharges plot in the "oxidized" corner of the plot. Giggenbach et al. (1990) note that low CH contents are likely due to prolonged interaction with water in the zone of aeration, or an otherwise oxidizing environment. In addition, the low concentrations of methane indicate that breakdown of organic material is contributing little methane to gas discharges (Mariner et al., 1983). Low

concentrations of $\mathrm{H}_{2} \mathrm{~S}$ and $\mathrm{H}_{2}$ are also present. These low concentrations may be due to prolonged interaction of flow paths with aerated ground water or an otherwise oxidizing environnent. Thus, the chemistry of geothermal gases 
TABLE IX

\section{CHEMISTRY OF ALVORD BASIN GAS DISCHARGES}

$\begin{array}{lc}\text { Spring } & \text { Alvord } \\ \text { Date } & 06 / 15 / 92 \\ \text { Temp, }{ }^{\circ} \mathrm{C} & 75.1 \\ & \\ \text { Volume } & \\ \mathrm{H}_{2} \mathrm{O} & 54.7 \\ \mathrm{CO} & 42.7 \\ \mathrm{~S} \text { (total) } & <.0085 \\ \mathrm{HCL} & 0.048 \\ \mathrm{He} & 0.003 \\ \mathrm{H}_{2} & 0.0004 \\ \mathrm{Ar} & 0.03 \\ \mathrm{O}_{2} & 0.33 \\ \mathrm{~N}_{2} & 2.104 \\ \mathrm{CH}_{4} & 0.034 \\ \delta^{13} \mathrm{CO}_{2} & -6.6 \\ \delta^{13} \mathrm{CH}_{4} & -27.8 \\ \mathrm{~N}_{2} / \mathrm{Ar} & 70.1 \\ \mathrm{He} / \mathrm{Ar} & 0.1 \\ \mathrm{Ar} / \mathrm{He} & 10 \\ \mathrm{CH}_{4} / \mathrm{CO}_{2} & 0.00008\end{array}$

\section{Borax}

06/14/92

93.4

14.8

76.5

$<.0260$

$<0.0740$

0.0025

0.101

0.18

0.913

7.34

0.0913

$-6.5$

$-33.6$

40.8

0.0139

72

0.0012
Mickey

06/14/92

94.6

$$
\begin{aligned}
& 99.3 \\
& 0.612 \\
& <0.0012 \\
& <0.0032 \\
& 0.00002 \\
& 0.0001 \\
& 0.0012 \\
& 0.0162 \\
& 0.0453 \\
& 0.0007 \\
& -9.4 \\
& -27.6 \\
& 39.2 \\
& 0.0167 \\
& 60 \\
& 0.0011
\end{aligned}
$$

Gas analyses performed by Dr. Neil Sturchio, Argonne National Laboratory, Argonne, Illinois. 
\#.4 Cold Waters

ㅁㅁㅁㅁ Borax Lake

... Springs north of Borax Lake

.... Alvord Hot Springs

- 000 Mickey Springs

-... Flowing well NE NE of Borax Lake

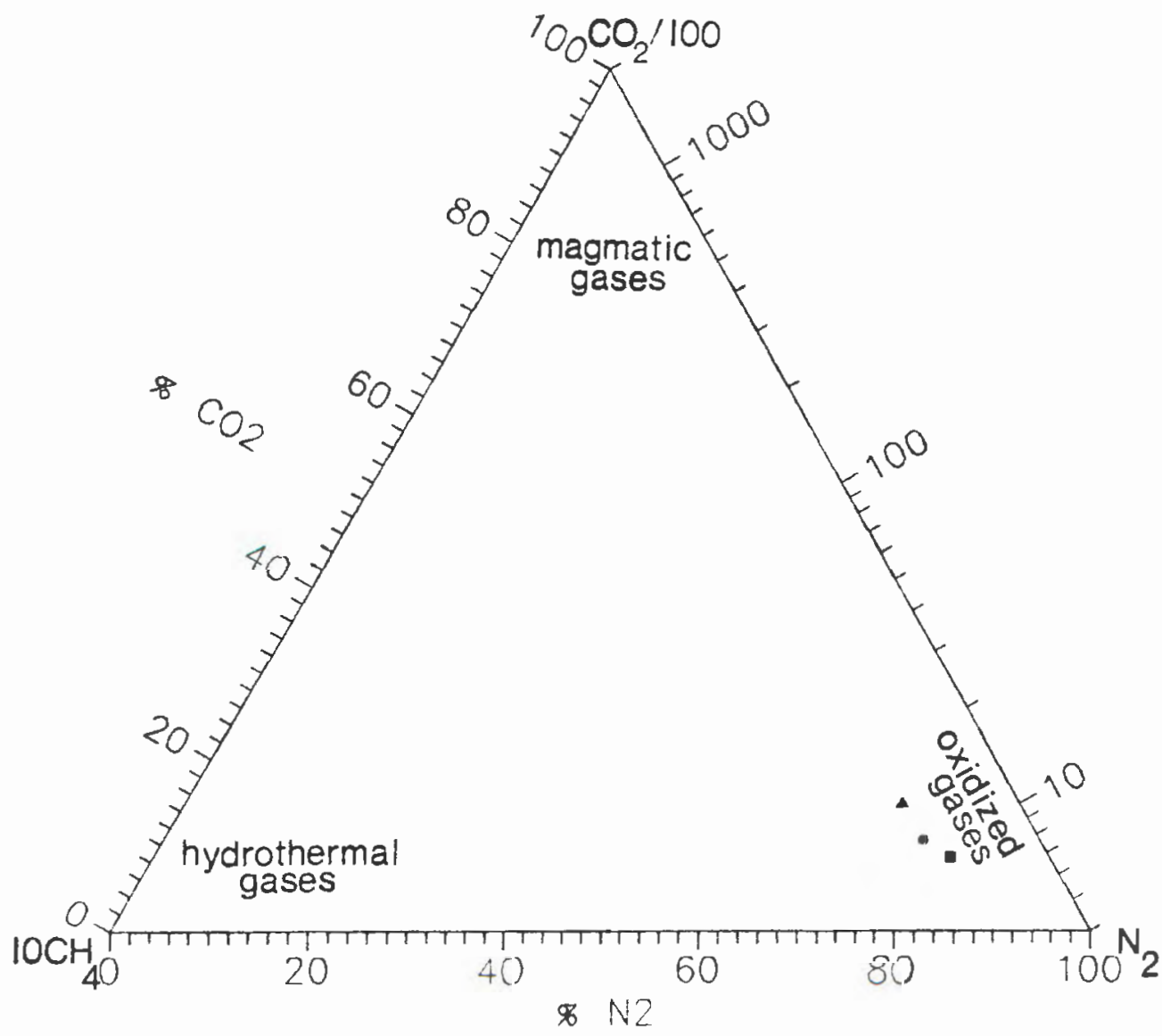

Eiqure 21. Relative $\mathrm{N}_{2}, \mathrm{CH}_{4}$ and $\mathrm{CO}_{2}$ contents in gas discharges on a molar (volume) basis. 
indicates that atmospheric oxidation is the dominant process in these geothermal systems (Giggenbach et al., 1990; Ellis, $1979)$.

Helium concentrations at Alvord Hot Springs are high relative to $\mathrm{N}_{2}$ and $\mathrm{Ar}$ (Figure 22 ). The increased helium concentration indicates increased residence times and/or low velocity of fluids (which liberate the gases) in the Earth's crust (Giggenbach and Goguel, 1989b).

Giggenbach and Goguel (1989b) note that $\mathrm{N}_{2}$, $\mathrm{Ar}$ and He contents of gases indicate different source components for gases. A meteoric component, represented by air-saturated ground water, contributes $N_{2}$ and $A r$ in the molar ratio of 38 and possibly somewhat higher, due to entrainment of air bubbles. On the other hand, a magmatic component is characterized by increase $\mathrm{N}_{2} / \mathrm{Ar}$ ratios of around 800 . The $\mathrm{N}_{2} / \mathrm{Ar}$ ratios for Alvord basin gases range from 39.2 to 70.1 . The $\mathrm{N}_{2} / \mathrm{Ar}$ ratios are close to air-saturated ground water for Mickey Springs and Borax Lake (38), while the sample from Alvord Hot Springs has a ratio closer to free air (84) (Giggenbach and Goguel, 1989b). The presence of free air could indicate possible air contamination during or after sampling for the Alvord Hot Springs sample. Relative $\mathrm{N}_{2}$, Ar and He contents are relatively close to that of airsaturated groundwater for Mickey Springs and Borax Lake (Figure 22), indicating an essentially atmospheric origin for these gases. 


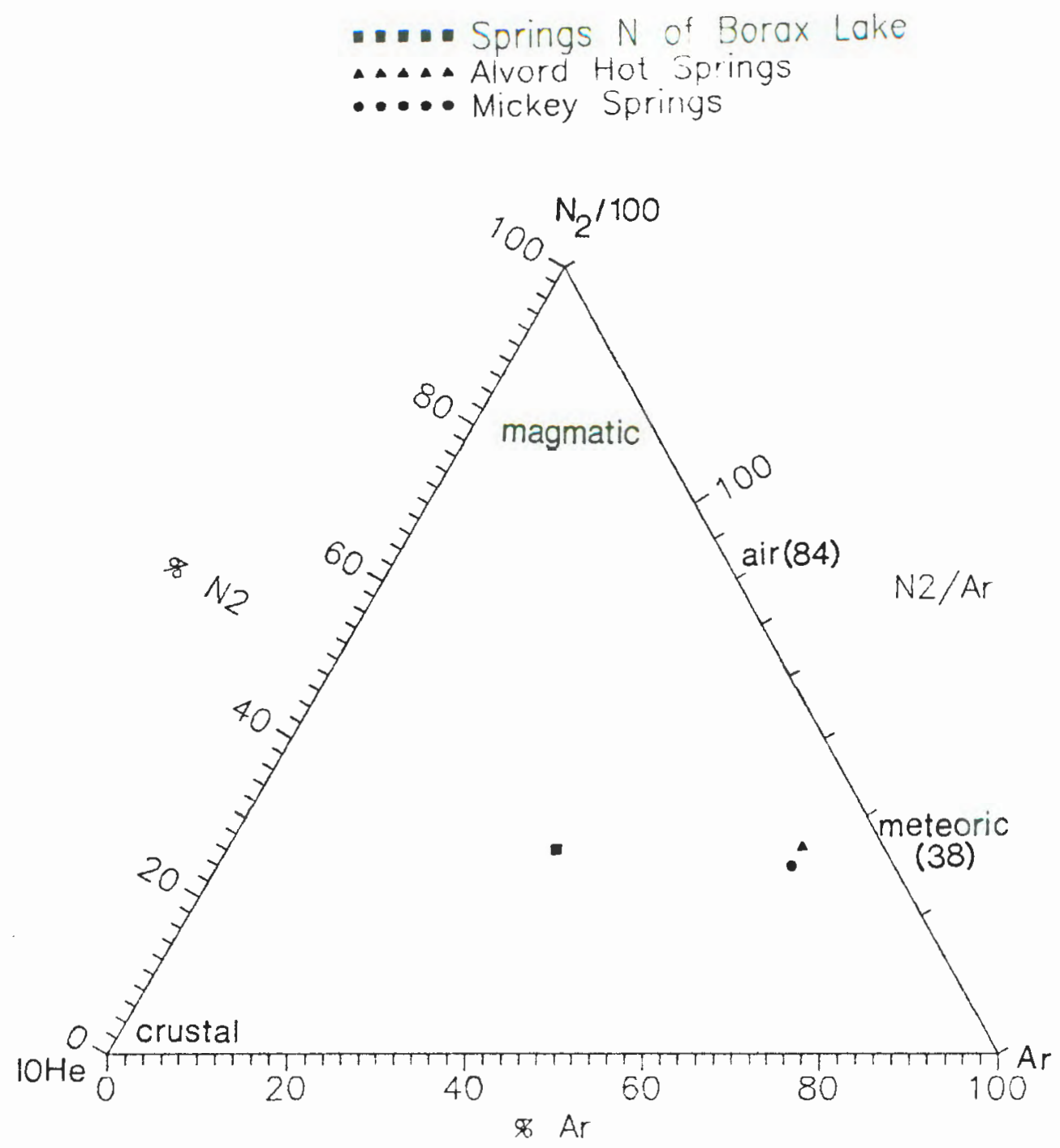

Figure 22. Relative $\mathrm{N}_{2}$, He and Ar contents in gas discharges on a molar (volume) basis. 
While ratios of $\mathrm{N}_{2} / \mathrm{Ar}$ indicate that gases originated from a solution of air in groundwater, Ar/He ratios show the presence of radiogenic He. Ar/He ratios for gas discharges are much lower than ratios for cold, air-saturated groundwater (approximately 7000)(Ellis, 1979). These ratios suggest the presence of a small component of radiogenic helium indicating long residence times and/or fluid-rock interaction in the Earth's crust for thermal fluids from Borax Lake and Mickey Springs. The very low $\mathrm{Ar} / \mathrm{He}$ ratio for gases from Alvord Hot Springs (10) argues for even longer residence times and/or more extensive fluid-rock interaction in the crust due indicated by increased concentrations of He. Figure 22 depicts the increased radiogenic He contribution for Alvord Hot Springs; gas discharges plot closer to the "crustal" corner than other gas samples.

\section{HOST LITHOLOGY OF THE RESERVOIR}

The host lithology of the geothermal reservoir may be assessed by analysis of the isotopic composition of various components of the geothermal fluids and gases. Strontium isotope ratios of thermal waters and rocks have been used to determine the lithology of the source reservoir in which fluids initially equilibrated (e.g. Goff et al., 1991b; Notsu et al., 1991; Graham, 1992). Radium isotope geochemistry has been employed by Sturchio et al. (1993) to explore aquifer lithology, water-rock interactions, 
temperature, and water chemistry in the Yellowstone hydrothermal system. Carbon isotopes have been used by Turi (1986) to determine the host rock lithology.

\section{Strontium Isotope Geochemistry}

The chemical behavior of strontium in groundwater is strongly linked to the nature of the aquifer rock through which it passes (e.g., Vuataz et al., 1988). Strontium isotope ratios have been used to determine reservoir rocks in geothermal systems (Graham, 1992; Goff et al., 1991b). The exchange of strontium between water and rock is mainly determined by chemical reaction (dissolution, precipitation or ion exchange) or possibly by equilibrium isotope exchange. During the process of chemical reaction, rocks may lose variable amounts of strontium to the circulating waters and, in this way, the waters gradually reflect the strontium isotope composition of their host rocks (Pampura et al., 1980). Alternatively, the circulating waters may lose strontium through the precipitation of calcite, barite or gypsum or ion exchange with clays and zeolites (Neil Sturchio, written communication, 1993). Because of this processes, strontium isotope ratios can be used to identify the country rocks with which fluids interacted. Assumptions inherent in the application of this technique include a knowledge of the stratigraphic sequence underlying the geothermal area and the confinement of water-rock interaction to the aquifer 
(Vuataz et al., 1988).

Conservative element ratios suggest volcanic or volcaniclastic reservoir rocks for the thermal areas in the Alvord basin. A reconstruction of the stratigraphic section underlying the basinal sediments in the Aivord basin includes an extensive section of Tertiary volcanic rocks (Tabie I). A comparison of strontium isotope ratios of fluids and rocks aid in further qualification of reservoir rock lithology for Alvord basin geothermal areas.

Strontium isotope ratios were determined for water samples collected from three hot springs in the Alvord basin (hot springs north of Borax Lake, Alvord Hot Springs, and Mickey Springs) in May, 1992. Discharges from all three thermal areas issue from basinal sediments. ${ }^{87} \mathrm{Sr} /{ }^{86} \mathrm{Sr}$ ratios for hot spring waters range from $0.70424 \pm 0.00005$ for the springs north of Borax Lake, $0.70439 \pm 0.00006$ for Mickey Springs, and $0.70478 \pm 0.00008$ for Alvord Hot Springs. Strontium contents range from 0.162 to $0.723 \mathrm{mg} / \mathrm{L}$ for thermal springs (Table $\mathrm{X}$ ).

To assess the source and input of strontium to Alvord basin geothermal waters, a suite of volcanic rocks were analyzed for ${ }^{87} \mathrm{Sr} /{ }^{86} \mathrm{Sr}$ ratios (Table $\mathrm{X}$ ). This suite of Tertiary volcanic rocks is believed to underlie the basinal fill in the Alvord basin. The samples are representative of the main units which may act as aquifers for the Alvord Valley Known Geothermal Resources Area. No samples of 
TABLE $X$

STRONTIUM ISOTOPE RATIOS FOR VOLCANIC ROCKS AND THERMAL FLUIDS FRON THE ALVORD BASIN AND SURROUNDING MOUNTAINS

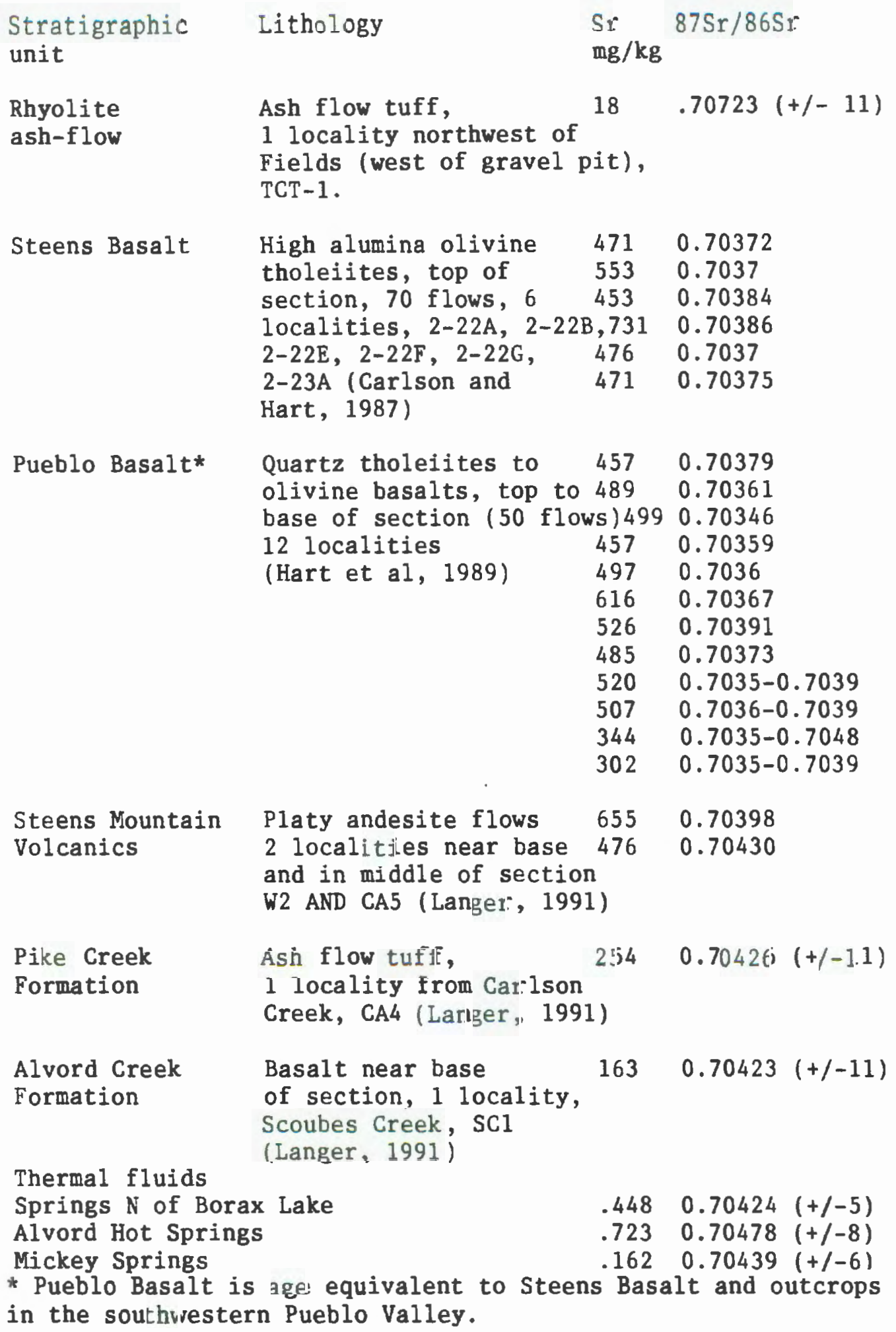


the basin fill were analyzed.

The results of $\mathrm{Sr}$-isotopic analyses of rocks indicate that the Tertiary volcanic rocks in the Alvord basin area have widely differing ratios ranging form 0.70422 (Alvord Creek Formation; Table X) to 0.70723 (peralkaline ash flow tuffs; Table $\mathrm{X}$ ). Some of the units have ${ }^{87} \mathrm{Sr} /{ }^{88} \mathrm{Sr}$ ratios higher than the fluids (e.g. tuff above Steens Basalt) and some have values lower than the fluids (e.g. Steens Basalt and Pueblo Basalt).

Assuming that thermal fluids have not lost or gained $\mathrm{Sr}$ during upflow, the following observations can be made. Fluids from the springs north of Borax Lake have a ${ }^{87} \mathrm{Sr} /{ }^{86} \mathrm{Sr}$ ratio consistent with interaction with welded ash flow tuffs of the Pike Creek Formation or fine-grained microcrystalline basalt of the Alvord Creek Formation thought to exist in the Alvord basin (Table X)(Figure 23). Fluids from Alvord Hot springs have a ${ }^{87} \mathrm{Sr} /{ }^{86} \mathrm{Sr}$ ratio higher than the Alvord Creek Formation and Pike Creek Formation (Figure 23). Fluids for Mickey Springs have a ${ }^{87} \mathrm{Sr} /{ }^{86} \mathrm{Sr}$ ratio consistent with interaction with andesite flows in the middle of the Steens Mountain Volcanics sequence thought to exist in the northern part of the Alvord Valley (Figure 23).

\section{Radium Isotope Geochemistry}

The relation between ${ }^{228} \mathrm{Ra} /{ }^{226} \mathrm{Ra}$, water chemistry and aquifer lithology has been noted by Clark and Turekian (1990) and Sturchio et al. (1993). Radium concentrations 


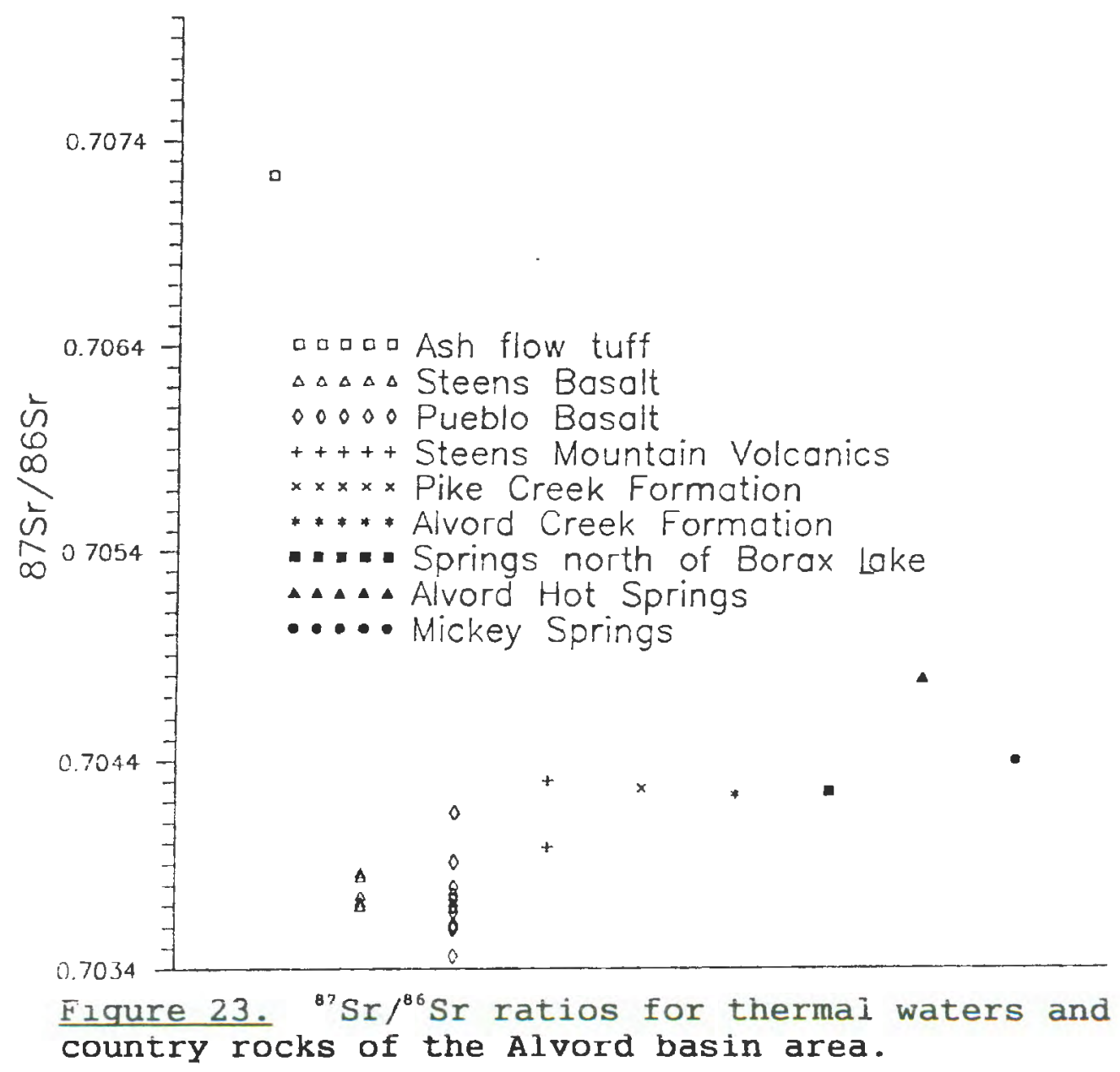


and isotopic activity ratios are presented in Table XI, along with information on the lithology of the discharge areas. The ${ }^{228} \mathrm{Ra} /{ }^{226} \mathrm{Ra}$ ratio for thermal fluids from the springs north of Borax Lake indicates interactions with volcanic rock. However, activity ratios for Alvord Hot Springs and Mickey Springs are lower than expected. These ratios could indicate either that the fluid has interacted with limestone or gypsum in either basinal sediments or buried blocks of pre-Tertiary sediments.(e.g. low ${ }^{229} \mathrm{Ra} /{ }^{226} \mathrm{Ra}$ ) or that uranium has accumulated along flow paths in the volcanic reservoirs (e.g. increased uranium would increase ${ }^{226} \mathrm{Ra}$ with respect to ${ }^{228} \mathrm{Ra}$ ) (Dr. Neil Sturchio, personal communication, December, 1992). Hence, Ra isotopic ratios indicate that reservoir rocks for the Borax Lake thermal area are volcanic while fluids from reservoir rocks at Mickey Springs and Alvord Hot Springs have interacted with

\section{TABLE XI}

RADIUM ISOTOPE RATIOS FOR THERMAL FLUIDS FROM THE ALVORD BASIN

\begin{tabular}{|c|c|c|c|}
\hline Spring Nave & $226 \mathrm{ne}, \mathrm{dp}=/ \mathrm{kg}$ & $228_{n+/ 226}{ }^{22 a}, d p=/ k g$ & $\begin{array}{l}\text { L1thology of } \\
\text { diechurge sone }\end{array}$ \\
\hline $\begin{array}{l}\text { Springe of } \\
\text { Borax Lake }\end{array}$ & $0.32 \pm 0.01$ & $1.14 \pm 0.13$ & $\begin{array}{l}\text { Quaternary } \\
\text { lacustriae } \\
\text { deposte }\end{array}$ \\
\hline Alvord got springe & $1.64 \pm 0.03$ & $0.38 \pm 0.02$ & $\begin{array}{l}\text { Quateracry } \\
\text { lecuetrine } \\
\text { doponite }\end{array}$ \\
\hline Mickey springs & $0.18 \pm 0.01$ & $0.17 \pm 0.09$ & $\begin{array}{l}\text { Quaterasery } \\
\text { olldeified } \\
\text { andetone } \\
\text { and lecustine } \\
\text { depost }\end{array}$ \\
\hline
\end{tabular}




\section{Carbon Isotope Geochemistry}

The $\delta^{13} \mathrm{C}$ values of $\mathrm{CO}_{2}$ in hot spring gases may also indicate reservoir host rock composition. Carbon species may be derived from various sources, including organic $\mathrm{CO}_{2}$, atmospheric $\mathrm{CO}_{2}$, limestone, and igneous sources (Faure, 1991). Systems with $\mathrm{CO}_{2}$ released from the decomposition of organic material have $\delta^{13} \mathrm{C}$ values ranging from -15 to $-25^{\circ} \%$ (Deines, 1980). Atmospheric $\mathrm{CO}_{2}$ has a $\delta^{13} \mathrm{C}$ value close to $7^{\circ} \%$ (Faure, 1991). Marine limestone has $\delta^{13} \mathrm{C}=0 \pm 4 \%$ (Craig, 1953). Carbon dioxide from igneous sources has $\delta^{13} \mathrm{C}$ values that vary over a wide range: Carbon dioxide liberated in fumaroles from volcanic areas normally has $\delta^{13} \mathrm{C}$ $=-8$ to $-3 \%$; $\mathrm{CO}_{2}$ collected over hot lavas has $\delta^{13} \mathrm{C}$ ranging from -26 to $-15 \%$ \% mantle-derived $\mathrm{CO}_{2}$ is thought to have ${ }^{13} \mathrm{C}$ values in the range of -8 to $-5 \%$ (Hoefs, 1987).

Figure 24 illustrates $\delta^{13} \mathrm{C}$ values for methane and carbon dioxide for different sources of hydrocarbon gases. Alvord basin gas discharges plot in the field for geothermal gases represented by data from New Zealand, Yellowstone and Lassen National Parks, and the Salton Sea region (Whiticar, 1990) .

Table IX presents $\delta^{13} \mathrm{C}$ values for $\mathrm{CO}_{2}$ gas from the thermal areas in the Alvord basin. The $\delta^{13} \mathrm{C}$ values for Alvord Hot Springs and the springs north of: Borax Lake are similar, while the $\delta^{13} \mathrm{C}$ value for Mickey Springs is isotopically lighter. 


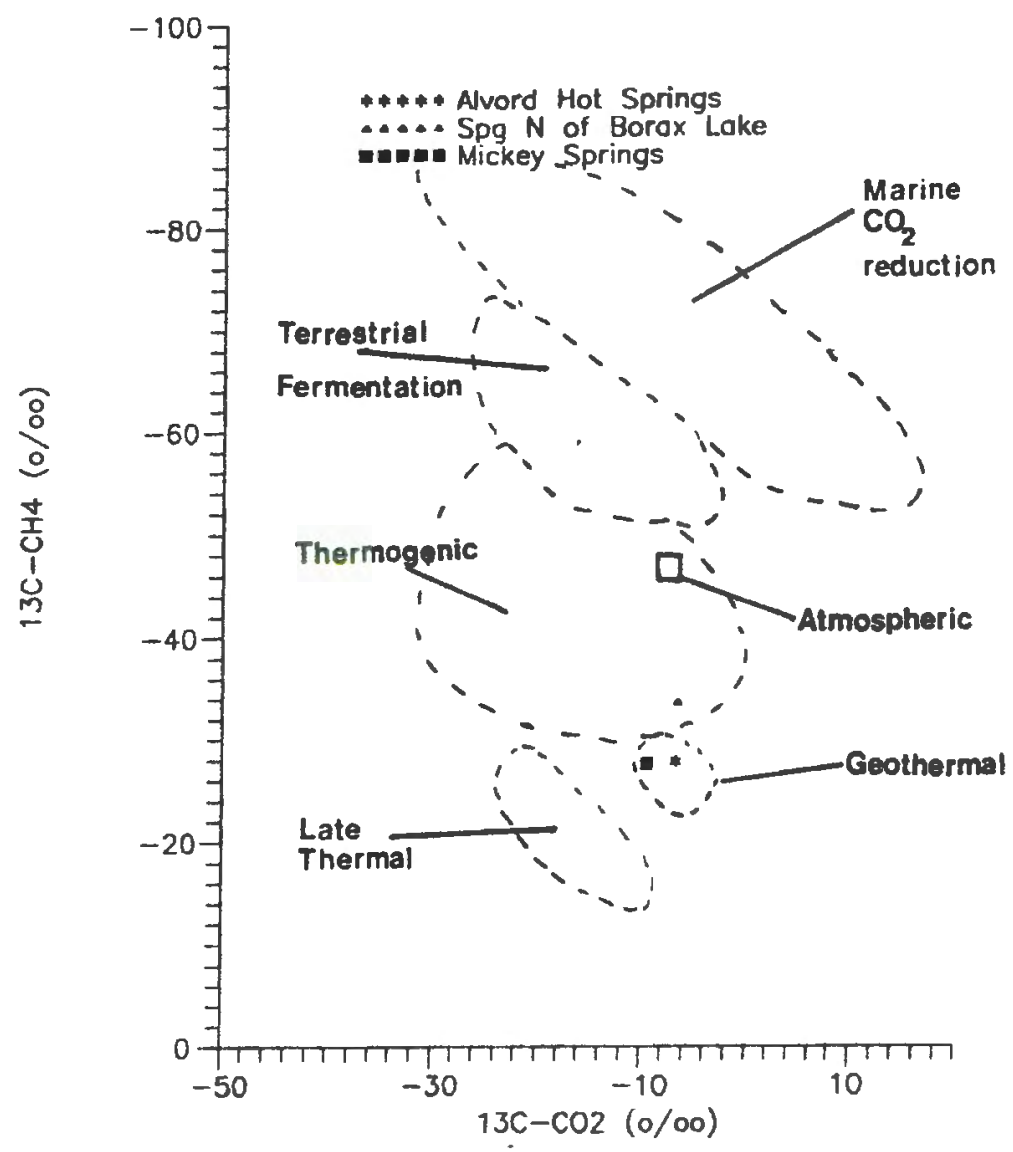

Fiqure 24. Gas sources determined from carbon isotope ratios of methane and carbon dioxide (adapted from Whiticar, 1990). 
The isotopic composition of gases for the springs north of Borax Lake and Alvord Hot Springs is within the range expected for either atmospheric oxygen, $\mathrm{CO}_{2}$ released from fumaroles, or mantle-derived $\mathrm{CO}_{2}$. The $\delta^{13} \mathrm{C}$ of $\mathrm{CO}_{2}$ for Mickey Springs is isotopically lighter than $\mathrm{CO}_{2}$ released from fumaroles or the mantle, but is considerably heavier than $\mathrm{CO}_{2}$ expected from the decomposition of organic matter or collected over hot lava flows.

In addition, the $\delta^{13} \mathrm{C}$ composition of methane $\left(\mathrm{CH}_{4}\right)$ from the three thermal areas may indicate different methane sources. The isotopic composition of "normal" geothermal methane is $-25 \%$ to $-29 \%$ (Figure 23)(Whiticar, 1990 and Stewart et al., 1992). Alvord Hot Springs and Mickey Springs are within this range $(-27.8 \%$ and $-27.6 \%$, respectively). However, the springs north of Borax Lake contain isotopically lighter methane $(-33.6 \%)$. Biogenic methane has a ${ }^{13} \mathrm{C}$ content of $-45^{\circ}$ \%o (Stewart et al., 1992). The springs north of Borax Lake may contain a component of thermogenic methane. Thermogenic signatures are generated by the thermal alteration of organic matter in rocks or sediments (Whiticar, 1990). In the case of the springs north of Borax Lake, thermogenic methane may be added to ascending hot sodium bicarbonate water containing "normal" geothermal methane gas; the thermogenic methane may be generated by thermal alteration of basinal sediments or preTertiary sediments. 
RESERVOIR GEOTHERMOMETRY

One of the major applications of geochemistry in the exploration of geothermal resources involves estimation of underground temperatures using chemical and isotopic geothermometers. Concentrations of dissolved constituents in geothermal fluids are a function of the temperature of the aquifer and the alteration mineral assemblage (White, 1965; Ellis, 1970; Truesdell, 1976). Any constituent whose concentration is controlied by a temperature-dependent reaction could, theoretically, be used as a geothermometer. However, to be useful as a geothermometer, additional conditions must be met. These conditions include an adequate supply of the reactant, establishment of equilibrium between water and minerals in the aquifer, little reequilibration or change in composition at lower temperatures as the water flows from the reservoir to the surface, and no mixing with shallow cold ground water (Fournier et al., 1974). The accuracy of the estimates depends upon the degree to which these assumptions are fulfilled (Fournier et al., 1974).

Although these assumptions may be fulfilled at some locations, they are not usually fulfilled everywhere. In particular, assumptions regarding the establishment of equilibrium between water and reservoir rocks, and the lack of reequilibration or mixing during upflow may be invalid. 
The application of chemical geothermometers is complicated by a lack of lithologic information for the geothermal reservoirs in the Alvord basin. Assumptions must be made concerning phases considered stable for a given host lithology in order to determine which reactions control particular chemical ratios employed in reservoir temperature estimates. The temperature range of $100-200^{\circ} \mathrm{C}$ is considered reasonable for systems in the Alvord basin. Phases considered stable include calcite, quartz, montmorillonite, albite, and wairakite for the $\mathrm{Ca}-\mathrm{Na}-\mathrm{K}-\mathrm{CO}_{2}-$ $\mathrm{Si}-\mathrm{H}_{2} \mathrm{O}$ system (Henley and Ellis, 1983).

Chemical, isotopic, and gas geothermometers and the conditions for their application to geothermal systems have been reviewed recently by Truesdell (1976), Ellis and Mahon (1977), Fournier (1981), Henley et al. (1984) and Kharaka and Mariner (1989). The commonly used chemical geothermometers (Table XII) include the silica geothermometers (Fournier and Rowe, 1966; Fournier, 1970), the Na-K-Ca geothermometer (Fournier and Truesdell, 1973), the Na-K geothermometers (White, 1965; Ellis, 1970; Truesdell, 1976; Fournier, 1979a), the Na-K-Mg-Ca "geoindicators" (Giggenbach, 1988), the oxygen isotope compositions of dissolved sulfate and water (Mckenzie and Truesdell, 1977), and various gas geothermometers (Giggenbach, 1980; D'Amore and Panichi, 1980; Norman and Bernhardt, 1981). 
In addition to the above conditions for the application of chemical geothermometers, certain geothermometers have special requirements. For example, the $\mathrm{K} / \mathrm{Na}$ and $\mathrm{K} / \mathrm{Mg}$ "geoindicators" of Giggenbach (1988) can be applied only if fluids are in equilibrium with the host rock. In order to evaluate the degree of fluid-rock equilibration, a "maturity index", MI, is calculated for a particular thermal fluid,

$$
M I=0.315 L_{k n}-L_{k n}=2.0,
$$

where $L_{k n}$ is equal to the $\log \left(K^{2} / \mathrm{Mg}\right)$ and $L_{k n}$ is equal to the $\log (\mathrm{K} / \mathrm{Na})$. An MI value greater than 2.0 indicates the suitability of a water for application of $\mathrm{K} / \mathrm{Na}$ and $\mathrm{K} / \mathrm{Mg}$ "geoindicators" (Giggenbach, 1988).

Giggenbach (1988) notes that $\mathrm{K} / \mathrm{Na}$ temperatures represent slow water-rock equilibration processes likely to reflect conditions at deeper levels, while "faster" geothermometers based on dissolved silica and $\mathrm{K} / \mathrm{Mg}$ contents provide information on temperatures at shallower levels.

A wide range of potential geothermometers originate from isotopic fractionation of an element between different compounds contained in geothermal fluids (Truesdell and Hulston, 1980). The most widely used isotope geothermometer involves the fractionation of oxygen between water and dissolved sulfate (McKenzie and Truesdell, 1977). This geothermometer completely equilibrates in geothermal reservoirs whose temperatures are above $150^{\circ} \mathrm{C}$ and reequilibrates only slightly in thermal fluids during ascent 
TABLE XII

EQUATIONS EXPRESSING THE TEMPERATURE DEPENDENCE

OF SELECTED GEOTHERMOMETERS

(AFTER FOURNIER, 1981)

$$
\begin{aligned}
& \text { Geothermometer Equation Restrictions } \\
& \begin{array}{l}
\text { Quartz- no steam } t^{\circ} \mathrm{C}=\frac{1309}{5.19-\log \left[\mathrm{SiO}_{2}\right]}-273.15 \quad t=0-250^{\circ} \mathrm{C} \\
\text { loss }
\end{array} \\
& \begin{array}{l}
\text { Quartz- maximum } \\
\text { steam loss }
\end{array} \quad t^{\circ} \mathrm{C}=\frac{1522}{5.75-10 \mathrm{og}\left[\mathrm{SiO}_{2}\right]}-273.15 \quad \mathrm{t}=0-250^{\circ} \mathrm{C} \\
& \mathrm{Na} / \mathrm{K} \text { (Fournier) } \quad \mathrm{t}^{\circ} \mathrm{C}=\frac{1217}{\log [\mathrm{Na} / \mathrm{K}]+1.483}-273.15 \quad \mathrm{t}>150^{\circ} \mathrm{C} \\
& \text { Na-K-Ca } \quad t^{0} \mathrm{C}=\frac{1647}{\begin{array}{ll}
\log [\mathrm{Na} / \mathrm{K}]+\mathrm{B}(\log [\mathrm{Ca} / \mathrm{Na}]+2.06)+2.47 \\
-273.15
\end{array}} \quad \begin{array}{c}
\mathrm{t}<100^{\circ} \mathrm{C}, \mathrm{B}=4 / 3 \\
\mathrm{t}>100^{\circ} \mathrm{C}, \mathrm{B}=1 / 3
\end{array}
\end{aligned}
$$

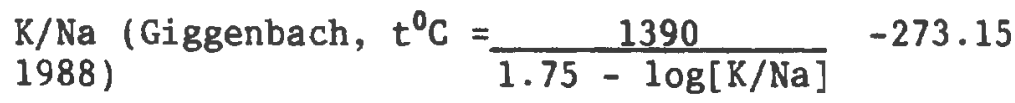

$$
\begin{aligned}
& \begin{array}{l}
\mathrm{K} / \mathrm{Mg} \text { (Giggenbach, } \\
1988 \text { ) }
\end{array} \quad t^{\circ} \mathrm{C}=\frac{4410}{14-\log \left[\mathrm{K}^{2} / \mathrm{Mg}\right]}-273.15
\end{aligned}
$$

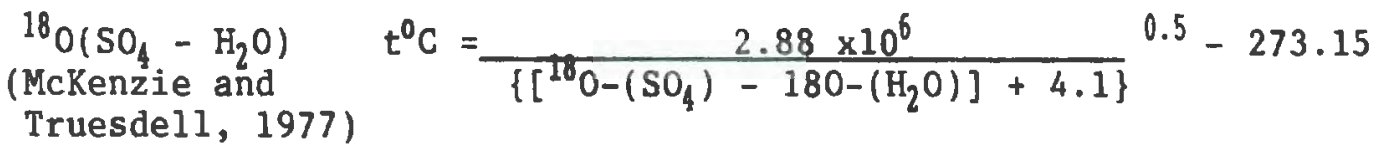

$$
\begin{aligned}
& \begin{array}{l}
\mathrm{CO}_{2}-\mathrm{H}_{2} \mathrm{~S}-\mathrm{CH}_{4}-\mathrm{H}_{2} \\
\text { (D'Amore and }
\end{array} \\
& t^{\circ} \mathrm{C}=\frac{24775}{\alpha+B+36.05}-273.15 \quad t=100-300 \\
& \text { Panichi, 1980) } \\
& \begin{array}{l}
\alpha=2 \log \underset{\mathrm{CO}}{\frac{\mathrm{CH}}{\mathrm{O}_{2}}}-6 \log \underset{\mathrm{H}_{2}}{\mathrm{H}_{2}}-3 \log \underset{\mathrm{CO}_{2}}{\mathrm{H}_{2}} \\
B=-7 \log \mathrm{P}_{\mathrm{CO}}
\end{array} \\
& 7 \text { if } \mathrm{CO}_{2}<75 \text { vol \%; } \mathrm{P}_{\mathrm{CO} 2}=0.1 \text { atm } \\
& 0 \text { if } \mathrm{CO}_{2}>75 \text { vol } \% ; \mathrm{CH}_{4}<2 \mathrm{H}_{2} ; \mathrm{H}_{2} \mathrm{~S}<2 \mathrm{H}_{2} ; \mathrm{P}_{\mathrm{CO} 2}= \\
& 7 \text { if } \mathrm{CO}_{2}>75 \text { vol \%; } \mathrm{CH}_{4}>2 \mathrm{H}_{2} ; \mathrm{H}_{2} \mathrm{~S}>2 \mathrm{H}_{2} ; \mathrm{P}_{\mathrm{CO} 2} \\
& \begin{array}{l}
{ }^{13} \mathrm{C}-\mathrm{CO}_{2}-{ }^{13} \mathrm{C}_{-} \mathrm{CH}_{4} \\
\text { (Bottinga, } 1969)
\end{array} \quad t^{0} \mathrm{C}=\frac{22166}{\left({ }^{13} \mathrm{C}-\mathrm{CO}_{2}-{ }^{13} \mathrm{C}-\mathrm{CH}_{4}\right)+13.861}-273.15 \\
& t^{0} \mathrm{C}=\frac{2048}{\log \left(\mathrm{CO}_{2} / \mathrm{Ar}\right)+7.53} \\
& \underset{\text { (Giggenbach, 1980) }}{\mathrm{CH}_{4}-\mathrm{CO}-\mathrm{CO}_{2}} \mathrm{t}^{0} \mathrm{C}=\frac{4625}{10.4+\log \left(\mathrm{CH}_{4} / \mathrm{CO}_{2}\right)} \quad-273.15 \\
& \left.\mathrm{H}_{2}-\mathrm{Ar} \text { (Giggenbach, } 1980\right) t^{0} \mathrm{C}=70\left(2.5+\log \left(\mathrm{H}_{2} / \mathrm{Ar}\right)\right.
\end{aligned}
$$


at average velocities. The geothermometer is affected by changes in $\delta^{18} O$ of water due to subsurface boiling anddilution and by addition of sulfate of near-surface origin (McKenzie and Truesdell, 1977).

Reservoir Temperatures

Thermal waters in the Alvord basin exhibit $\mathrm{Na}-\mathrm{HCO}_{3}$ composition. Giggenbach and Goguel (1989b) note that most of the waters involved in the calibration of empirical geothermometers are full equilibrium Na-Cl waters. They further note that most $\mathrm{Na}-\mathrm{HCO}_{3}$ waters, which are commonly found at the periphery of many geothermal systems, are generated by absorption of $\mathrm{CO}_{2}$-rich geothermal steam in shallow ground water. These $\mathrm{Na}-\mathrm{HCO}_{3}$ waters are not full equilibrium waters and cannot be used for geothermometric purposes. However, it must be noted that calculated maturity indices based on thermal fluid composition for Alvord basin thermal areas are greater than 2, indicating full fluid-rock equilibration in the Na-K-Ca system.

Table XIII presents estimated reservoir temperatures based on chemical, isotopic, and gas geothermometry for the Alvord basin. The adiabatic (maximum steam loss) rather than conductive (no steam loss) quartz estimates are more applicable for samples with near-boiling or boiling measured temperatures, as is the case for Borax Lake, the hot springs north of Borax Lake and Mickey Springs. In addition, subsurface boiling is indicated at Mickey Springs by the 
high $\mathrm{pH}$ and low $\mathrm{CO}_{2}$ concentration (Goff et al., 1987).

$\mathrm{K} / \mathrm{Na}$ temperature estimates are consistently higher than other geothermometers; Giggenbach (1988) notes that this "geoindicator" responds the most slowly and therefore preserves deep equilibration $\mathrm{Na} / \mathrm{K}$-ratios in the reservoir. However, he cautions that the production of similar ratios in waters obviously not in equilibrium with the rock generates large uncertainties in its application as a geothermometer.

$\mathrm{K} / \mathrm{Mg}$ temperature estimates are consistently lower than other geothermometers; Giggenbach (1988) notes that this "faster geoindicator" reequilibrates quickly at shallow levels and is sensitive to the addition of nonequilibrated waters.

Temperature estimates using the gas geothermometers are either consistently lower or higher than chemical and isotopic geothermometer estimates (Table XIII). Estimates range from $157-345^{\circ} \mathrm{C}$ for the springs north of Borax Lake. The $\mathrm{H}_{2}-\mathrm{Ar}$ estimate, based on equilibrium between dissolved Ar and $H_{2}$ and gaseous $A r$ and $H_{2}$, is similar to measured downhole temperatures in exploration wells drilled in the vicinity of Borax Lake $\left(160^{\circ} \mathrm{C}\right.$, Blackwell et a1., 1986; $152^{\circ}$ C, Anadarko Petroleum Corporation Press Release, 1989). Estimates range from $33-360^{\circ} \mathrm{C}$ for Alvord Hot Springs. The low $\mathrm{H}_{2}-\mathrm{Ar}$ estimate for Alvord Hot Springs may have resulted from air contamination of the sample (as indicated by a 
IABLE XIII

CBEMICAL, ISOTOPIC AND GAS GEOTHERMOHETRY FOR FEE ALVORD VALLEY KGRA

\begin{tabular}{|c|c|c|c|c|c|c|c|c|c|c|c|c|c|}
\hline Location & Date & $\begin{array}{l}\text { Geothernoneter } \\
\text { Quartz } \\
\text { lo Stean loss }\end{array}$ & $\begin{array}{l}\text { Quartz } \\
\text { Max. Stean Loss }\end{array}$ & $\mathrm{Na} / \mathrm{K}$ & $\mathrm{Ha}-\mathrm{K}-\mathrm{Ca}$ & $\mathrm{X} / \mathrm{Na}$ & $\mathbb{N} / \mathbb{M g}$ & $\begin{array}{l}\text { Isotope } \\
\text { 180(SO4 - } \mathrm{B} 20)\end{array}$ & \multirow[t]{2}{*}{$\begin{array}{l}\text { Gas } \\
\mathrm{CO2}-\mathrm{B} 2 \mathrm{~S}-\mathrm{CH} 4-\mathrm{B} 2\end{array}$} & \multirow[t]{2}{*}{$\mathrm{CO}-\mathrm{CH} 4$} & $\mathrm{~B} 2-\mathrm{Ar}$ & $\mathrm{CH} 4-\mathrm{CO} 2$ & $13 \mathrm{C}(\mathrm{CO} 2)-13 \mathrm{C}(\mathrm{CH} 4)$ \\
\hline Borax Lake & & & & & & & & & & & & & \\
\hline $96.4^{\prime}$ & $06 / 91$ & & & 181 & 183 & 199 & 145 & & & & & & \\
\hline $91^{\prime}$ & $09 / 91$ & & & 174 & 177 & 184 & 142 & & & & & & \\
\hline $93^{\prime}$ & $12 / 91$ & 185 & 172 & 174 & 166 & 192 & 141 & & & & & & \\
\hline $93^{\prime}$ & $03 / 92$ & 175 & 164 & 176 & 172 & 194 & 144 & & & & & & \\
\hline $93^{\prime}$ & $06 / 92$ & 189 & 176 & 180 & 158 & 198 & 141 & 207 & & & & & \\
\hline $93^{\prime}$ & $09 / 92$ & 178 & 167 & 177 & 172 & 195 & 140 & & & & & & \\
\hline \multicolumn{14}{|c|}{ Springs of } \\
\hline \multirow[t]{6}{*}{ Borax Lake } & $06 / 91$ & & & 195 & 162 & 211 & 134 & & & & & & \\
\hline & $09 / 91$ & & & 172 & 168 & 189 & 138 & & & & & & \\
\hline & $12 / 91$ & 171 & 161 & 176 & 163 & 193 & 136 & & & & & & \\
\hline & $03 / 92$ & 175 & 164 & 171 & 166 & 189 & 133 & & & & & & \\
\hline & $06 / 92$ & 189 & 176 & 189 & 154 & 206 & 137 & 203 & 126 & 224 & 157 & 345 & 268 \\
\hline \multirow{2}{*}{\multicolumn{14}{|c|}{ Alvord lot Springs }} \\
\hline & & & & & & & & & & & & & \\
\hline & $06 / 91$ & & & 182 & 202 & 199 & 140 & & & & & & \\
\hline & $09 / 91$ & & & 182 & 193 & 199 & 137 & & & & & & \\
\hline & $12 / 91$ & 157 & 149 & 181 & 193 & 198 & 138 & & & & & & \\
\hline & $03 / 92$ & 152 & 145 & 180 & 191 & 197 & 137 & & & & & & \\
\hline & $06 / 92$ & 161 & 152 & 180 & 189 & 198 & 134 & 198 & 33 & 238 & 44 & 360 & 359 \\
\hline \multirow{2}{*}{\multicolumn{14}{|c|}{ Kickey Springs }} \\
\hline & & & & & & & & & & & & & \\
\hline & $06 / 91$ & & & 175 & 199 & 193 & 157 & & & & & & \\
\hline & 09/91 & & & 169 & 198 & 187 & 185 & & & & & & \\
\hline & $12 / 91$ & 193 & 179 & 174 & 197 & 191 & 164 & & & & & & \\
\hline & $03 / 92$ & 185 & 172 & 170 & 194 & 188 & 175 & & & & & & \\
\hline & $06 / 92$ & 192 & 176 & 168 & 196 & 186 & 190 & 150 & 90 & 225 & 100 & 347 & 418 \\
\hline & $09 / 92$ & 190 & 176 & 176 & 200 & 194 & 167 & & & & & & \\
\hline \multicolumn{14}{|c|}{ Vloving Vell } \\
\hline IE Borax Lak & $12 / 91$ & 197 & 182 & 178 & 175 & 199 & 115 & & & & & & $\stackrel{n}{N}$ \\
\hline & $09 / 92$ & 194 & 180 & 184 & 174 & 202 & 115 & 168 & & & & & $\omega$ \\
\hline
\end{tabular}


$\mathrm{N}_{2} / \mathrm{Ar}$ ratio close to that of air). Estimates range from 90$418^{\circ} \mathrm{C}$ for Mickey Springs. The $\mathrm{H}_{2}-\mathrm{Ar}$ and $\mathrm{CO}_{2}-\mathrm{H}_{2} \mathrm{~S}-\mathrm{CH}_{4}-\mathrm{H}_{2}$ estimates are similar to measured thermal spring temperatures possibly suggesting reequilibration in the near-surface environment. There is relatively good agreement between $\mathrm{H}_{2}-\mathrm{Ar}$ and $\mathrm{CO}_{2}-\mathrm{H}_{2} \mathrm{~S}-\mathrm{CH}_{4}-\mathrm{CO}-\mathrm{H}_{2}$ estimates for all thermal areas. The $\mathrm{CH}_{4}-\mathrm{CO}-\mathrm{CO}_{2}$ and carbon isotope estimates correlate well for Alvord Hot Springs. $\mathrm{CH}_{4}-\mathrm{CO}_{-} \mathrm{CO}_{2}$ estimates are similar for the thermal areas $\left(>300^{\circ} \mathrm{C}\right)$. These estimates do not seem reasonable when compared with other chemical and isotopic geothermometer estimates (Table XIII). Giggenbach (1987) notes that temperatures based on carbon isotope distribution between $\mathrm{CO}_{2}$ and $\mathrm{CH}_{4}$ are usually 50-150 C higher than reservoir temperatures. These high values are interpreted to indicate the slow rates of $\mathrm{CO}_{2}-\mathrm{CH}_{4}$ isotopic exchange in deep geothermal fluid reservoirs.

Borax Lake Thermal Area. The estimated reservoir temperatures based on the chemical and isotopic geothermometers for Borax Lake range from $140^{\circ} \mathrm{C}$ to $207^{\circ} \mathrm{C}$. The highest temperatures are obtained from the $\mathrm{K} / \mathrm{Na}$ "geoindicator" of Giggenbach (1988) and the oxygen isotope geothermometer. The oxygen isotope geothermometer is approximately $8^{\circ} \mathrm{C}$ higher than the "geoindicator". The quartz geothermometers, $\mathrm{Na} / \mathrm{K}$, and $\mathrm{Na}-\mathrm{K}-\mathrm{Ca}$ geothermometers are, on average, within $12^{\circ} \mathrm{C}$ of each other. The $\mathrm{K} / \mathrm{Mg}$ "geoindicator" produces the lowest temperatures $\left(142^{\circ} \mathrm{C}\right)$. 
Anadarko Petroleum Corporation encountered a temperature of $152^{\circ} \mathrm{C}$ at a depth of approximately $450 \mathrm{~m}$ during exploratory drilling $2.2 \mathrm{~km}$ south of Borax Lake (Anadarko Press release, November 7,1989$)$. This value lies between the estimates produced by quartz geothermometry with maximum steam loss, $\mathrm{Na}-\mathrm{K}-\mathrm{Ca}$ and $\mathrm{K} / \mathrm{Mg}$ estimates for Borax Lake.

Estimated reservoir temperatures for the hot springs north of Borax Lake range from $132^{\circ} \mathrm{C}$ to $203^{\circ} \mathrm{C}$. Similar relations among the values of different geothermometers and "geoindicators" as obtained from Borax Lake are present, but the maximum temperatures for the $\mathrm{K} / \mathrm{Na}$ and isotope geothermometers are higher (average $198^{\circ} \mathrm{C}(\mathrm{n}=6)$ and $203^{\circ} \mathrm{C}$ respectively). The $\mathrm{K} / \mathrm{Mg}$ temperature values are lower than those for Borax Lake. A particularly low temperature estimate (and lower $\mathrm{Ca}$ content) was obtained for the Na-K-Ca system in June, 1992, a time when calcite was actively being deposited at the spring.

Estimated reservoir temperatures for the flowing well northeast of Borax Lake range from $115^{\circ} \mathrm{C}$ to $202^{\circ} \mathrm{C}$. The silica geothermometers and $\mathrm{Na} / \mathrm{K}, \mathrm{Na}-\mathrm{K}-\mathrm{Ca}$, and $\mathrm{K} / \mathrm{Na}$ values are generally higher than the average temperatures obtained for the same systems at Borax Lake and the springs north of Borax Lake. The isotope geothermometer is 35 to $40^{\circ} \mathrm{C}$ lower than isotopic estimates for the other two springs. The $\mathrm{K} / \mathrm{Mg}$ "geoindicators" produces temperatures $\left(115^{\circ} \mathrm{C}\right)$ that are 20 to $30^{\circ} \mathrm{C}$ lower than for the other sites. 
Sulfate-water values are approximately $8^{\circ} \mathrm{C}$ higher or lower than geothermometer estimates Eor Borax Lake and the hot springs north of Borax Lake (Table XIII). These values are similar to those obtained from the silica and cation geothermometers.

The isotopic geothermometers yield reservoir temperatures for Borax Lake and the springs to the north that are similar $\left(207^{\circ} \mathrm{C}\right.$ versus $\left.203^{\circ} \mathrm{C}\right)$. While these sites have similar reservoir temperature estimates, isotopic-based estimates for the flowing well located $0.80 \mathrm{~km}$ northeast of Borax Lake are $35^{\circ} \mathrm{C}$ to $39^{\circ} \mathrm{C}$ lower than Borax Lake and the springs to the north.

Mickey Springs Thermal Area. Estimated reservoir temperatures for Mickey Springs range from $140^{\circ} \mathrm{C}$ to $200^{\circ} \mathrm{C}$. General agreement for the conductive quartz geothermometer, $\mathrm{Na}-\mathrm{K}-\mathrm{Ca}$, and $\mathrm{K} / \mathrm{Na}$ between 190 and $199^{\circ} \mathrm{C}$ (averages) are obtained at Mickey Springs. The highest $\mathrm{K} / \mathrm{Mg}$ temperatures are obtained at Mickey Springs relative to the other hot spring areas. These temperatures are in close agreement with the average temperature for the quartz (maximum steam loss) geothermometer. The oxygen-sulfate geothermometer yields a low temperature estimate relative to the other geothermometers $\left(150^{\circ} \mathrm{C}\right)$.

Alvord Hot Springs Thermal Area. Estimated reservoir temperatures for Alvord Hot Springs range from $113^{\circ} \mathrm{C}$ to $204^{\circ} \mathrm{C}$. The highest temperature estimates are obtained from 
the $\mathrm{Na}-\mathrm{K}-\mathrm{Ca}$ and $\mathrm{K} / \mathrm{Na}$ systems while $\mathrm{Na} / \mathrm{K}$ and the oxygen isotope geothermometers, although yielding lower temperatures, are in agreement. The estimates obtained for the quartz-based geothermometers are, on average, 25 to $50^{\circ}$ $C$ lower than the other geothermometers. The lowest temperatures are attained for the $\mathrm{K} / \mathrm{Mg}$ system at an average value of $137^{\circ} \mathrm{C}(\mathrm{n}=6)$. The agreement in calculated temperatures for each of the six sampling periods is much tighter than obtained for the Borax Lake area. 
DISCUSSION

Borax Lake, Alvord Hot Springs, and Mickey Springs are the discharge areas in the Alvord basin for geothermal systems that recharge in surrounding fault block mountains, particularly the Steens Mountain-Pueblo Mountains fault blocks. The hydrologic dymamics of the groundwater and surface water components within the fault block mountains and valley are only partially known, but are believed to be similar to those postulated for other closed basin systems in the Great Basin (Mifflan, 1968, 1988; Russell, 1985; Sammel and Craig, 1981; Welch and Preissler, 1987; Campana et al., 1980; Olmsted et al., 1984).

The basic feature of this model (Mifflan, 1968, 1988) is range-to-valley flow of meteoric water. Recharge of the valley groundwater systems occurs by streams, fed from precipitation in the mountain ranges, that disappear into the alluvial fans that prograde valley ward from the mountain front (Townley et al., 1980). Deeper circulating meteoric water may discharge into the basin from faults which occur along the basin margin. At least some of the precipitation migrates to greater depths along fracture zones within the fault block mountains and, in a region of high heat flow, becomes heated before rising along rangefront faults to discharge as hot springs within the basin. 
In this discussion, the data obtained from geologic mapping and the geochemical and isotopic concentrations for fluids and rocks are examined in relation to the characteristics of the geothermal reservoirs in the basin.

\section{HYDROGEOCHEMISTRY AND RESERVOIR CHARACTERISTICS}

Geothermal fluids obtain isotopic and chemical characteristics by interaction with the rocks through which they pass. The characteristics impressed upon the fluids and gases reflect the lithology where the fluids and gases were resident for the longest time (reservoir) and under the highest sustained temperature conditions. Certain characteristics are relatively resistent to modification by interactions with rocks through which the fluid may pass while migrating to the surface. Other characteristics may become modified. However, these modifications may indicate the behavior of the fluid during migration and the rock types through which it passes. A thermall fluid at the Earth's surface has isotopic and chemical characteristics that are a sum of all processes that have acted upon that fluid during its evolution. In order to understand the dymamics of the geothermal systems in the Alvord basin, the characteristics imposed during recharge, residency in the reservoir, and upflow must be discussed. 
Recharge

Recharge of the geothermal systems in the Alvord basin occurs primarily by infiltration of meteoric water from the Steens Mountain fault block, but lesser volumes of water may be contributed from the smaller ranges such as the Sheepshead Mountains and Trout Creek Mountains. The $\delta D$ values of thermal water, cold groundwater, pore water from cores collected at 4 to $5 \mathrm{~m}$ depth from Alvord Lake (Matthews, written communication, 1991), and surface runoff from the eastern slope of steens Mountain are similar (Table VI). These values are lower than the $\delta D$ value for snow collected at $2,408 \mathrm{~m}$ on the western flank of Steens Mountain. Due to the considerable elevation differences on Steens Mountain, the isotopic composition of rain and snow could vary considerably.

The of value for one sample of precipitation collected from the basin floor (Table VI) is considerably higher than that of the thermal and non-thermal waters. This datum does not allow an evaluation of precipitation falling on the valley floor contributing to the fiuids in the system. However, considering the rain shadow effect of the steens Mountain-Pueblo Mountains on the Alvord basin, it is unlikely that precipitation falling on the valley floor contributes to the groundwater system. In like manner, $\delta \mathrm{D}$ and $\delta^{18} O$ values for pore water from the upper $4 \mathrm{~m}$ of sediment in Alvord Lake are more enriched than fluids in the 
groundwater system. It is unlikely that this water, in which the $D$ and ${ }^{11} O$ values have been enriched due to evaporation, contributes to the recharge of the geothermal system operating in the basin.

Differences in the $\delta^{18} \mathrm{O}$ values between cold groundwater and thermal waters result from interaction of the thermal water with rocks under the conditions of the reservoir. The characteristic shift to the right of the world meteoric water line (to higher $\delta^{10} \mathrm{O}$ values) in thermal waters is consistent with high temperature exchange between "0depleted waters and ${ }^{10} \mathrm{O}$ rocks (Figure 17 ).

Although local meteoric water dominates most geothermal systems (Truesdell and Hulston, 1980), other sources of fluid may contribute to the system. These sources may include magmatic fluids, basinal brines, and metamorphic fluids. Conservative element ratios in discharge fluids, elemental ratios in gases, and isotopic ratios may indicate the presence of these fluids. All ratios considered in this study support a meteoric water origin of the geothermal fluids. While $\delta^{13} \mathrm{C}\left(\mathrm{CO}_{2}\right)$ values for gases from Borax Lake and Alvord Hot Springs are within the allowable range for mantle derived $\mathrm{CO}_{2}$, the isotopic composition at these springs also overlaps that of atmospheric and fumarolic ${ }^{13} \mathrm{C}\left(\mathrm{CO}_{2}\right)$ values. Ratios of $\mathrm{N}_{2}$ and $\mathrm{Ar}$ at Borax Lake and Mickey Springs indicate recharge by air-saturated ground water, suggesting that the $\mathrm{CO}_{2}$ is of atmospheric origin. 
On the basis of the available data, the recharge for the Alvord basin geothermal systems is meteoric water derived from precipitation falling on the Steens MountainPueblo Mountains. No other sources of fluids are confirmed.

Residence Times in the Reservoir

The isotopic and chemical compositions of reservoir host rocks impart characteristic signatures to the waters. The interaction of fluids with rocks at elevated temperatures involves a variety of reactions to occur. In geothermal systems, the most likely reactions are dissolution/precipitation, oxidation/reduction, and cation and isotopic exchange reactions. Under equilibrium conditions the elemental and isotopic distributions between the fluid and rock are fixed for a given temperature. Whether equilibrium is attained is, in part, related to the residence time of the fluid and within the reservoir.

The fluid residence time en route from the area of recharge to the area of discharge was examined by analysis of the tritium content of the thermal fluids, cold ground water, and surface waters. Tritium analyses indicate that the thermal waters and cold ground waters from deep sources share a long residence time that may be from at least 57 years to greater than 10,000 years, depending upon the circulation model selected for evaluation of the data. Cold water discharging from shallow ground water sources or 
discharging directly from the Steens Mountain fault block have residence times of months to a few years. The deep groundwater and thermal waters of the Alvord basin have little or no tritium and are largely isolated from the shallow cold groundwaters of the basin. The low concentration of tritium in the thermal waters suggests that thermal fluids contain a small amount of young water either due to 1) mixing in the near-surface environment or to 2) mixing with relatively young, deeply circulating ground water.

Increased He contents relative to $\mathrm{N}_{2}$ and $\mathrm{Ar}$ contents in gas discharges from Alvord Hot Springs are consistent with relatively long residence times of gas and fluid in the crust (Figure 22)(Giggenbach and Goguel, 1989b).

The shift in $6^{18} 0$ values up to $3 \%$ relative to the world meteoric water line, is consistent with oxygen exchange with isotopically heavier rocks at elevated temperatures. However, several other chemical and isotopic signatures also may be ascribed to the interactions of fluids with rocks. These can be interpreted in terms of the equilibration temperature of the fluid and the host rock lithology of the reservoir.

\section{Reservoir Temperature}

Chemical and isotopic geothermometers indicate reservoir temperatures between $170^{\circ} \mathrm{C}$ and $200^{\circ} \mathrm{C}$. These estimates are in general agreement with reservoir 
temperatures calculated by Mariner and others $(1974,1980)$ and Brown and Peterson (1980). The general agreement among calculated results using a variety of geothermometers that are dependent upon different dissolution and exchange reactions within the reservoir suggest that an assumption of chemical equilibrium between fluids and rocks is reasonable.

\section{Host Rock Lithology}

The attainment of equilibrium allows additional arguments related to the location of the reservoir to be advanced. The composition of the reservoir rocks may be interpreted from ratios of various elements in solution including the conservative elements, and strontium and radium isotope ratios. Conservative element ratios are consistent with the reservoir being located within a volcanic host rock. The strontium and radium isotopic ratios more precisely define the lithology of the reservoir.

Sparse strontium isotopic data are avaliable for the volcanic rocks of southeastern Oregon. Isotopic data for the Steens Basalt and the age-equivalent Pueblo Basalt are reported by Carlson and Hart (1987) and Hart et al. (1989) as indicated in Table $\mathrm{X}$. However, for all other stratigraphic units, the results reported in this study are the only known values.

The strontium isotopic ratios $\left({ }^{87} \mathrm{Sr} /{ }^{86} \mathrm{Sr}\right)$ for two samples collected near the base and middle of the steens 
Mountain Volcanics indicate that considerable isotopic variability may exist in some units (Table $X$ ). The isotopic composition of rhyolite, basalt, and andesite from all exposed units below Steens Basalt have Sr isotopic ratios of 0.7040-0.7043. The Steens Basalt and the andesite flows from near the base of the Steens Mountain Volcanics have Sr isotope ratios of $0.7037-0.7039$, and 0.7040 and 0.7043 , respectively. The isotopic differences between these two "groups" are significant. However, from stratigraphic relations, it is clear that rocks having less radiogenic $\mathbf{S r}$ are interbedded with rocks with more radiogenic Sr. Both "groups" are isotopically distinct from peralkaline ash flow tuff and presumably associated tuffs from above the steens Basalt $\left({ }^{87} \mathrm{Sr} /{ }^{86} \mathrm{Sr}=0.7072\right)$.

The strontium isotopic ratios for thermal waters (Table $x)$ are consistent with those for rocks below the steens Basalt and most closely match those of the more radiogenic units of the steens Mountain Volcanics and the rhyolite and basalt of the Pike Creek and Alvord Creek Formations, respectively (Figure 23). Since the range of isotopic values in these formations is not known, the host rock for the reservoir cannot be more rigorously defined on the basis of the available $\mathrm{Sr}$ isotope analyses. However, the Cs/Li ratio for a water sample from Borax Lake is consistent with the reservoir located in rhyolite.

Radium isotopes in fluids from the springs north of 
Borax Lake also are consistent with a reservoir located in volcanic rocks. At Mickey Springs and Alvord Hot Springs, the apparent lower activity ratios may be explained by uranium accumulation in the reservoir or in rock through which the fluids passed during ascent. Uranium ore was mined at various locations in southeastern Oregon (i.e. Weissenburger, 1984). Approximately $70 \mathrm{~km}$ southeast of the Alvord basin, the Aurora and Bretz uranium prospects are located along ring fractures of the McDermitt caldera. The Bretz prospect occurs in silicic lavas and rhyolite ash-flow tuff while the Aurora prospect is hosted in intracaldera tuffaceous lake sediments (Wallace and Roper, 1981; Roper and Wallace, 1981). A similar lithologic association is likely in the northern Alvord basin.

\section{Upflow}

In order to examine the changes in the thermal fluids during migration of water to the surface to be discharged at the hot springs in the Alvord basin, it is assumed that the fluids equilibrated with the reservoir rock. Hot water ascending to the surface from a deep geothermal reservoir may cool by conduction of heat to the surrounding rock, by boiling, by mixing with cooler shallow water, or by a combination of these processes (Fournier, 1979b). Figure 25 is a diagram showing some of the processes which may occur in the upflow zone of a geothermal system.

Each process may modify the chemical composition of the 
fluid that left the deep reservoir. In the most simple case, hot water may cool adiabatically or conductively and flow rapidly from the deep reservoir without mixing with shallow cold water, thereby preserving the chemical signature of the deep reservoir. However, the water may reside for various lengtins of time in different reservoirs at different depths and temperatures $\left(R_{1}, R_{2}\right.$ and $R_{3}$ and $t_{3}>$ $t_{2}>t_{3}$ in Figure 25 ). The fluids may reequilibrate in these shallow reservoirs and/or mix with shallow groundwater. Fluids may also reach the shallow subsurface and then flow laterally.

The first process to consider is mixing with nonthermal or thermal water of different composition. White (1970) argued that mixing is demonstrated by variations greater than 10 percent in the chloride concentrations of thermal fluids over time. Table $V$ summarizes seasonal variations in chloride content for thermal springs in the Alvord basin. Changes in the chloride concentration from season to season are less than 10 percent for all thermal springs except the springs north of Borax Lake. In these springs, the variations range from 10 to 15 percent from March to September of 1992. White (1970) notes that if the maximum variations are only slightly more than 10 percent, the differences are likely to be caused by a single fluid of constant chloride composition undergoing evaporative concentration by boiling in central spring channels. The 


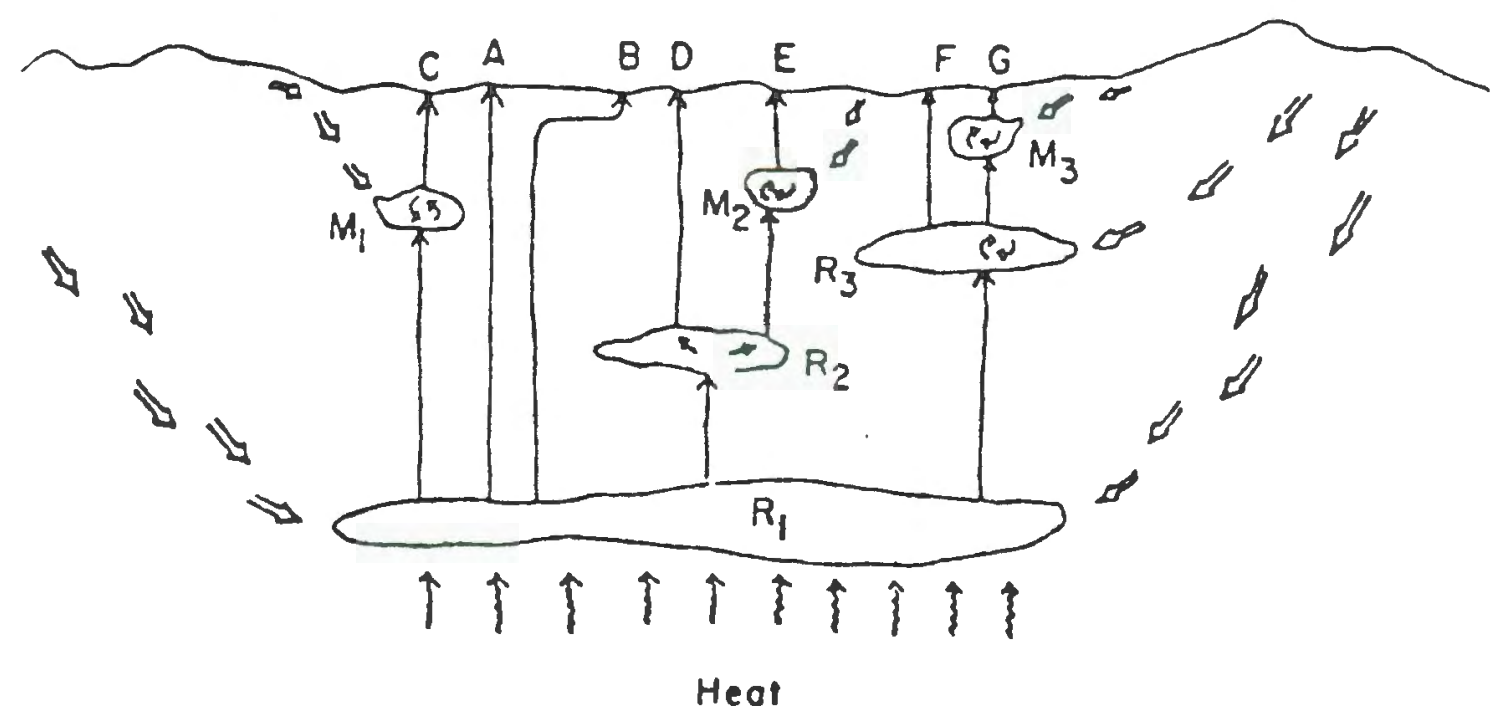

Fiqure 25. Schematic section through a hypothetical hot-spring system. The stippled areas represent reservoirs of hot water with the temperature of $R_{1}>R_{2}>R_{3}>100^{\circ} \mathrm{C}$. Hot springs emerge at points $A$ through $G$. Each spring illustrtates a different condition of upward flow that may affect the water temperatures and the chemical composition: $A=$ direct to surface from $R_{1}$; adiabatic cooling with fast flow and conductive cooling with slow flow. $B=$ horizontal flow near the surface; conductive cooling possible even with fast flow. $C$ = direct to surface from $R_{1}$, but mixing with colder water at $M_{1}$ on the way without chemical equilibration after mixing. $D=$ chemical reequilibration in intermediate reservoir $R_{2}$. $E$ = after reequilibration in $R_{2}$, mixing with colder water at $M_{2}$; no chemical reequilibration after mixing. $F$ = chemical reequilibration after mixing with cold water in shallow reservoir $R_{3}$. G $=$ mixing with colder water after leaving $R_{3}$; no chemical reequilibration after mixing at $M_{3}$ (From Fournier, 1979b). 
data in Table $\mathrm{V}$ indicate that mixing with non-thermal waters or thermal waters of different salinity is not occurring in the Alvord basin with the possibie exception of the springs north of Borax Lake where mixing may be slight.

Low tritium concentrations are present in thermal waters at all hot springs. However, these values are higher than those in the deep non-thermal waters (Table VIII). The residence times indicated by the tritium content of the thermal waters ranges from 3,400 to 8,500 years assuming a well-mixed model. The deep non-thermal waters have calculated residence times of greater than 10,000 years.

The tritium concentrations in thermal waters may be ascribed to 1 ) mixing with a small amount of tritium-bearing water near the point of discharge, or 2) deep circulation of a relatively small volume of "young" water to the level of the deep reservoir where it is mixed and heated with "old" deep groundwater. In the first case, the volume of tritiumbearing water must be small enough so as not to produce shifts in chloride content greater than about 5 to $8 \%$ (Table $v$ ), or to destroy the $\delta^{18} \mathrm{O}$ shift in thermal water relative to non-thermal water. The lack of tritium in the discharge from the flowing well northeast of Borax Lake suggests that this is the most likely model. If this is the case, then approximately 1 to 3 mixing of water with a tritium concentration of 7.50 T.U. (Pike Creek) would account for the observed tritium concentrations in thermal fluids. A 
higher percentage of cold water is required if the tritium concentrations are contributed by mixing with cold water resident in the shallow ground water system for some period of time (e.g. Thomas well or Kurtz well). While tritium data do not preclude mixing at deep levels where both hot and cold waters are old and lack tritium, differentiation of the two fluid types is not possible considering the chemical and isotopic techniques employed in this study.

If mixing with non-thermal water or thermal water having different salinity is not occurring in the Alvord basin, the differences in the composition of discharge from different springs may be produced during boiling of the thermal water. As hot water rises to the surface, the pressure imposed on it by the column of overlying water decreases. Water leaving the deep reservoile at a temperature between 170 and $200^{\circ} \mathrm{C}$ begins to boil at a depth of 100 to $180 \mathrm{~m}$ beneath the surface (Figure 26). Once boiling commences, the temperature/depth relations in the rising thermal fluid are constrained along the liquid-vapor curve of water. Boiling hot springs, such as Mickey Springs, hot springs north of Borax Lake, and water discharging into the bottom of Borax Lake, indicate that the fluid has remained constrained on the boiling curve to the surface. However, as indicated in Figure 25, fluids may not rise rapidly to the surface and may spend various lengths of time in different reservoirs that have differing conditions. 


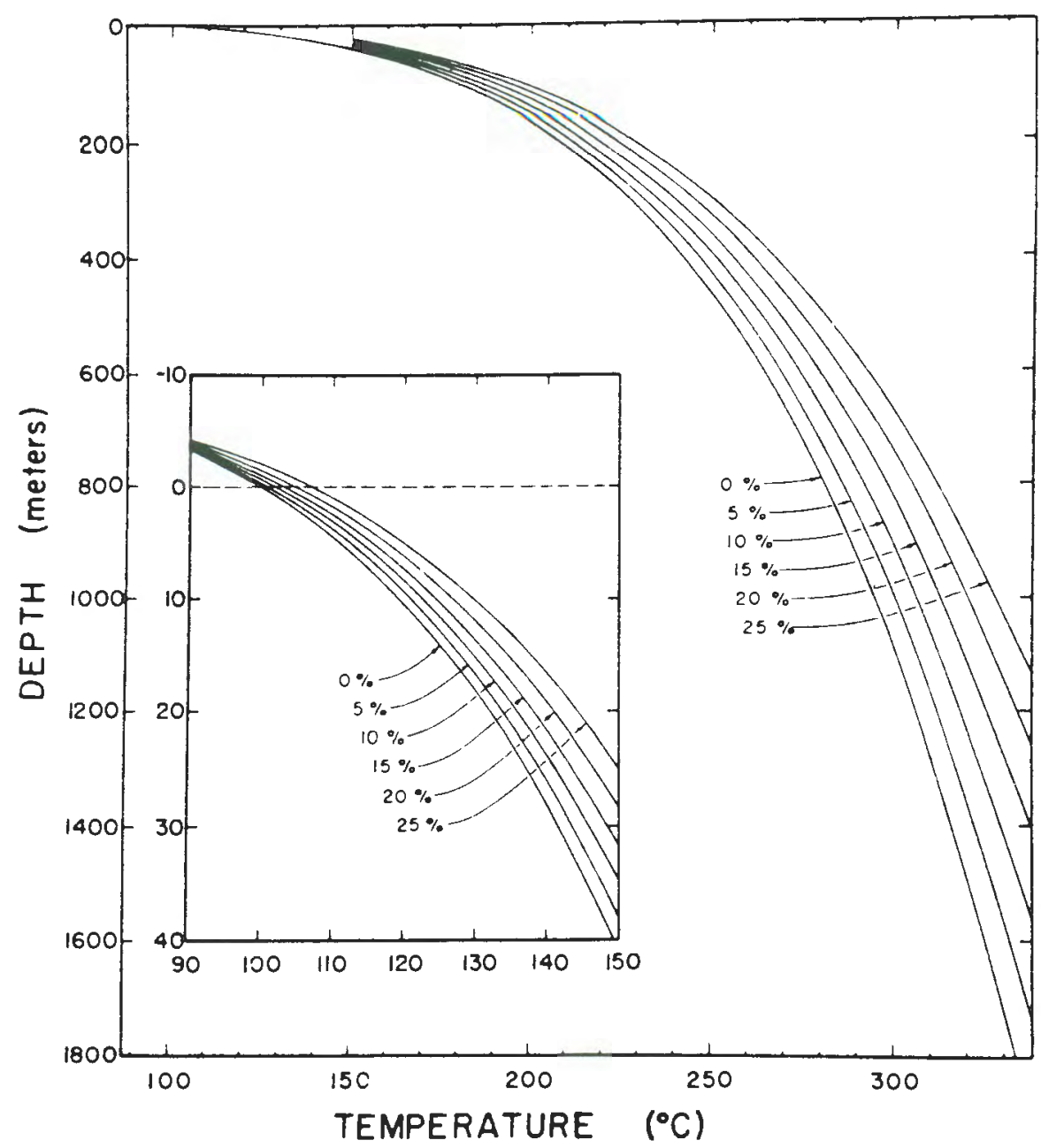

Figure 26. Depth vs. boiling curve for waterdominated fluids (from Truesdell, 1985). 
It is during these relatively short residences in shallow reservoirs that a boiling solution may partially reequilibrate and change composition.

Boiling of a geothermal fluid generates a steam phase into which is fractionated volatile constituents originally dissolved in the fluid. A thermal water may be modified by mixing in shallow aquifers with water produced by condewnsation of steam generated from boiling of deeper fluids. In this setting, oxidation of $\mathrm{H}_{2} \mathrm{~S}$ by atmospheric oxygen to produce sulfate may occur. The sulfate-enriched condensate may mix with the continuously boiling solution as it rises.

The highest sulfate concentrations occur in thermal waters at Borax Lake, the springs north of Borax Lake, and the flowing well northeast of Borax Lake. The $N_{2} /$ Ar ratios in gases collected from a spring north of Borax Lake may represent water that is boiling. At Borax Lake and the springs north of Borax Lake, the $\mathrm{SO}_{4}-\mathrm{H}_{2} \mathrm{O}$ geothermometer indicates a high temperature $\left(>200^{\circ} \mathrm{C}\right)$ of sulfate formation. Dissolved oxygen in recharge waters could have oxidized $\mathrm{H}_{2} \mathrm{~S}$ or pyrite at depth to form $\mathrm{SO}_{4}$ at depth. However, the $\mathrm{SO}_{4}-\mathrm{H}_{2} \mathrm{O}$ and $\mathrm{K} / \mathrm{Mg}$ geothermometers indicate considerably lower temperatures for the non-boiling flowing well northeast of Borax Lake. In addition, the flowing well discharges more dilute, lower $\mathrm{pH}$ water than Borax Lake or the springs north of Borax Lake. The reequilibration of the 
$\mathrm{SO}_{4}-\mathrm{H}_{2} \mathrm{O}$ geothermometer and low $\mathrm{K} / \mathrm{Mg}$ temperature estimates indicate that this water may have undergone mixing with a near-surface sulfate-rich water and reequilibrated (e.g. Point $F$ on Figure 25).

Although the $\mathrm{SO}_{4}$ content is not as high, reequilibration of the sulfate-water system in a shallow aquifer is also indicated at Mickey Springs. The low concentration of constituents other than $\mathrm{H}_{2} \mathrm{O}$ in the gas sample from Mickey Springs suggests that the majority of the major gas constituents have been stripped out. The variable $\mathrm{K} / \mathrm{Mg}$ "geoindicator" values for this site $\left(157-190^{\circ} \mathrm{C}\right)$ for thermal fluids suggests partial reequilibration of cation geothermometers during residence in a shallow hot water aquifer (e.g. Point $D$ in Figure 25).

Boiling at shallow depths during ascent to the surface and variable residence time in shallow reservoirs appear to be the most important factors producing differences in the geochemistry of thermal fluids discharging at boiling springs .

The chemistry of fluids from non-boiling springs at Alvord Hot Springs and the flowing well northeast of Borax Lake also indicate reservoir temperatures in the range of 170 to $200^{\circ} \mathrm{C}$. The lack of boiling at the surface indicates a flow path that has allowed conductive heat loss to the surrounding rocks. The situation at the flowing well northeast of Borax Lake was discussed above. 
Water discharging at Alvord Hot Springs has silica geothermometers that are 30 to $50^{\circ} \mathrm{C}$ lower than the alkalibased geothermometers. Boiling and slow heat loss can lead to the precipitation of silica from the solution. The springs also discharge water with the highest concentration of $\mathrm{Cl}^{-}$and total dissolved solids. The chemical composition of these fluids suggest slow rise and/or low volume of the fluid and conductive heat loss to the surrounding rocks. The chemical composition of fluids discharging at Alvord Hot Springs could be generated by deep mixing with a $\mathrm{He}-$ and $\mathrm{Cl}-$ rich fluid, equilibration at $200^{\circ} \mathrm{C}$ and slow cooling during ascent (e.g. Point $A$ - direct flow from $R_{1}$ and conductive cooling with slow flow - on Figure 25).

\section{Depth of Thermal Fluid Circulation}

Recharge occurs in the steens Mountain fault block where meteoric water infiltrates along major faults, circulates to great depths along these faults, possibly mixes with Cl-rich fluids, becomes heated and equilibrates in various host rocks, and rises along basin-bounding faults (Alvord Hot Springs and Mickey Springs) or along intrabasinal faults (Borax Lake thermal area).

Cleary (1976) estimated the depth of circulation for the thermal areas in the Alvord basin. He concluded that the minimum depth of circulation was $1.4 \mathrm{~km}$ for all of the thermal areas from calculations based on thermal reservoir temperature estimates $\left(170-193^{\circ} \mathrm{C}\right)$, thermal conductivity of 
associated rocks $\left(4.5 \times 10^{-3} \mathrm{cal} / \mathrm{cm} \mathrm{sec}{ }^{\circ} \mathrm{C}\right)$, and heat flow $\left(4.5-5.5 \times 10^{-6} \mathrm{cal} / \mathrm{cm}^{2} \mathrm{sec}\right)$. Other researchers have estimated greater depths of circulation. Blackwell et al. (1978), noting a geothermal gradient of $40-60^{\circ} \mathrm{C} / \mathrm{km}$ argued for a minimum depth of circulation for fluids to reach an inferred reservoir temperture of $190^{\circ} \mathrm{C}$ would be $4-5 \mathrm{~km}$. Blackwell et al. (1986) noted that the minimum depth of circulation for fluids to reach the highest observed temperature in observations wells arilled in the area of Borax Lake $\left(160^{\circ} \mathrm{C}\right)$ would be $3-4 \mathrm{~km}$.

Fluid circulation depth estimates presented in this study are based on stratigraphic thickness and ${ }^{87} \mathrm{Sr} /{ }^{86} \mathrm{Sr}$ ratios for Tertiary volcanic units. The combined stratigraphic thickness of units exposed on the east-facing scarp of Steens Mountains and presented in Table $I$ is 1.5 $\mathrm{km}$. From gravity surveys, the depth to bedrock (e.g. Steens Basalt) is $0.4 \mathrm{~km}$ under Alvord Lake and $0.6 \mathrm{~km}$ under Alvord Desert (Griscom and Conradi, 1975). Exploratory drilling by Anadarko Petroleum Corporation southwest of Borax Lake encountered fractured basalt at a depth of $347.5 \mathrm{~m}$ (Blackwell et al., 1986). Based on this information, the depth to the top of the Steens Mountain Volcanics is approximately $1.3 \mathrm{~km}$, to the Pike Creek Formation is approximately $2 \mathrm{~km}$, and to the Alvord Creek Formation is approximately $2.5 \mathrm{~km}$ in the Borax Lake area. Strontium isotope ratios of thermal fluids from Borax Lake are 
consistent with reservoir location within these three units. Cs/Li ratios suggest that the likely host is the ash flow that makes up the Pike Creek Formation. Hence, ground water circulates to a depth of at least 2 to $2.5 \mathrm{~km}$ in the Borax Lake thermal area (Figure 4).

Gravity surveys indicate a depth to basement of $0.6 \mathrm{~km}$ under Alvord Desert with maximum depths occurring along the western margin of the basin (below Steens Mountain) (Griscom and Conradi, 1975). Maximum depths to magnetic material (basement rock) were calculated using magnetic profiles from the middle of the Alvord Desert; the maximum depths range from 400 to $500 \mathrm{~m}$. In addition, gravity surveys indicate that Alvord Hot Springs is located directly above a normal fault which bounds the basin on the west (Cleary, 1976). Interpretation of strontium isotope ratios and geophysical data imply that fluids circulate to a minimum depth of 2-3 km and, possibly, to greater depths along the basin-bounding fault near Alvord Hot Springs.

Mickey Springs is located above a fault that juxtaposes materials of different densities (Griscom and Conradi, 1975). However, the gravity data may be interpreted to indicate a small basin approximately $75 \mathrm{~m}$ deep in the area of the springs. Strontium isotope ratios of fluids indicate equilibration in the volcanic rocks beneath the Steens Basalt (Table X). Hook (1981) noted that corfelation of Mickey ignimbrite between Mickey Mountain and an Anadarko 
Petroleum Corporation exploration well, ANA-5, located in the north end of Mickey Basin, indicates $850 \mathrm{~m}$ of displacement across the range-front fault in the Mickey Springs area. Assuming a thickness for Steens Basalt of 1 $\mathrm{km}$, ground water circulates to a minimum depth of $1.2-2.0 \mathrm{~km}$ in the Mickey Springs thermal area.

\section{CONCEPTUAL MODEL OF THERMAL FLUID CIRCULATION IN THE ALVORD BASIN}

A general model for thermal fluid circulation in the Alvord basin is presented in Figure 27. The conceptual model of thermal water flow for the Alvord basin is based on conclusions drawn from hydrogeochemical and isotopic data for thermal and non-thermal waters. The model involves recharge from the surrounding fault block mountains, in particular, the Steens Mountain-Pueblo Mountains fault block. The meteoric water circulates to depth along faults and is heated by anomalously high regional heat flow in volcanic rocks located beneath the Steens Basalt. The heated water migrates laterally along permeable zones within these volcanic rocks and rises to the surface along rangefront faults or intrabasinal faults. During ascent, the thermal water is largely isolated from mixing with nonthermal water or waters rising from geothermal reservoirs not located in the same stratigraphic units. Boiling, variable flow rate and associated conductive heat loss, and mixing with minor amounts of condensate and/or near-surface 
water occurs during ascent. The process from recharge to discharge occurs over a span of time that is potentially greater than 10,000 years.

The question remains whether the three thermal areas are fed from a single deep-seated reservoir or three separate reservoirs.

The distance of 23 to $25 \mathrm{~km}$ between the thermal springs led White and Williams (1975) to infer that Borax Lake, Alvord Hot Springs, and Mickey Springs are three separate systems and are not connected at depth in a single large geothermal reservoir. The data presented in the present study do not rule out the possibility of one large, deepseated geothermal reservoir discharging to shallow reservoirs or directly to the surface at the three thermal areas.

If all three thermal areas discharge from a single, deep-seated geothermal reservoir, the following processes occurring during upflow produce the chemical and isotopic differences detected in water at the different springs.

At Alvord Hot Springs, low-volume discharge and/or low flow rates along the Alvord fault segment of the steens Mountain fault zone allow for conductive heat loss with limited boiling from He-rich fluids, increases in salinity, deposition of silica, and oxidation of $\mathrm{H}_{2} \mathrm{~S}$.

At Mickey Springs steam released during boiling of the hydrothermal solution heats cold groundwater to the point of 


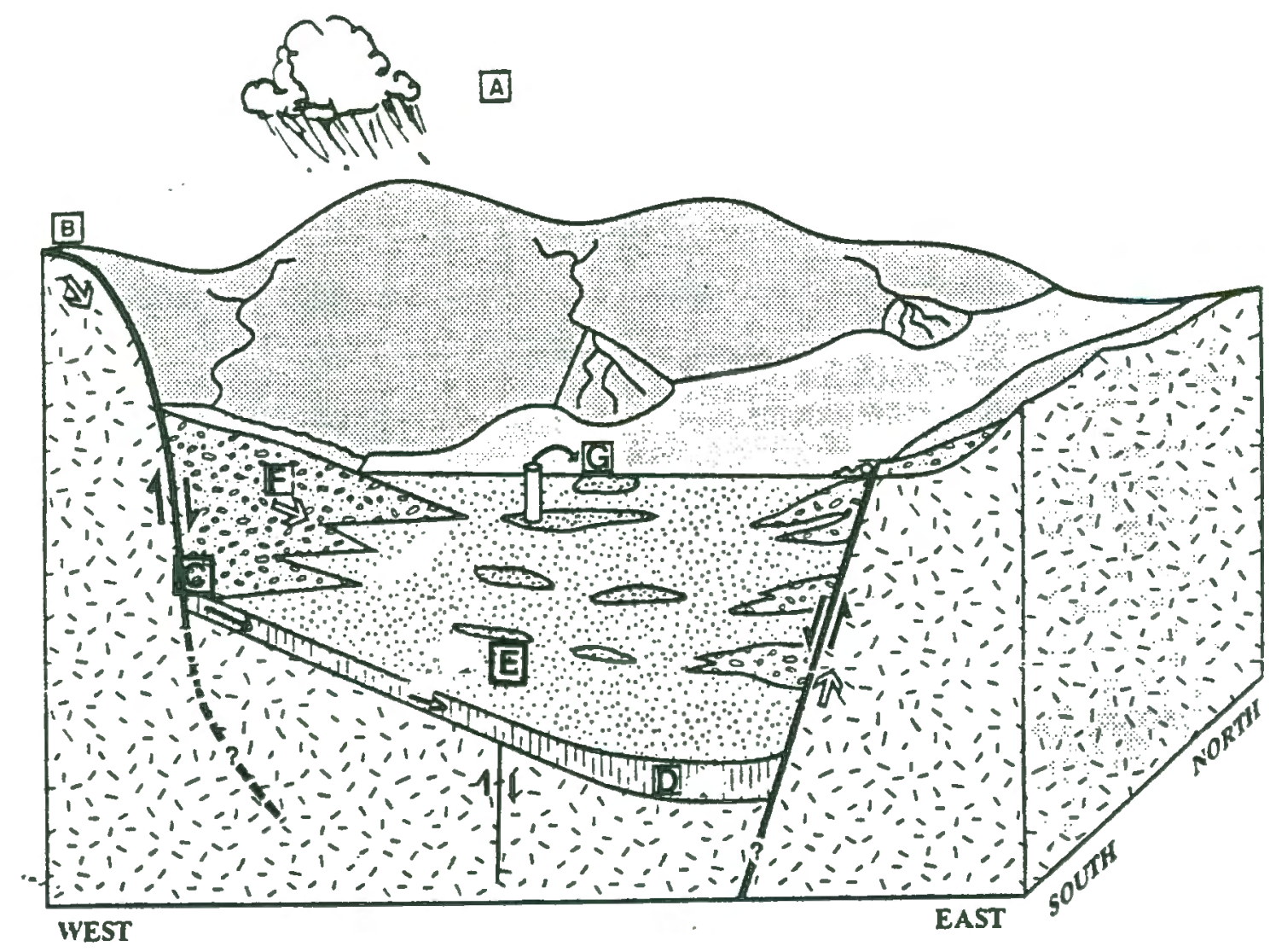

Fiqure 27. Schematic block diagram showing conceptual model of thermal fluid circulation in the Alvord basin. Precipitation in the mountains (A) recharges thermal aquifers through faults and fractures (B) in the Steens Mountain fault block. Thermal fluid circulates in volcanic rocks and ascends along basin-bounding faults with surface discharge localized along major basin-bounding faults in the western part of the basin (C). Hot water flows laterally in volcanic rocks and ascends along intrabasinal faults (D). Recharge of cold groundwater through alluvial fans and near basin-bounding faults (E). Surface discharge of cold groundwater from confined basin-fill aquifers (modified from Welch and Preissler, 1987). 
boiling. This steam-heated water produces steaming ground, mud volcanoes and fumaroles. The thermal water rises along separate structures to discharge as a boiling hot spring that, under the proper conditions, displays geysering behavior. Low calcium concentrations and relatively high $\mathrm{pH}$ suggest mineral precipitation from the thermal fluid in the subsurface.

At Borax Lake water from the deep-seated geothermal reservoir rises into the Steens Basalt and forms a shallow reservoir that probably extends into basinal fill. Sulfatewater geothermometry indicates a temperature of greater than $200^{\circ} \mathrm{C}$ for deep fluids. A small contribution of thermogenic $\mathrm{CH}_{4}$ from thermal breakdown of organic matter is also present. The main discharge occurs at boiling springs north of Borax Lake and in the bottom of Borax Lake. The flowing well northeast of Borax Lake exhibits chemical and isotopic characteristics similar to those of Borax lake and the springs north of Borax Lake and thus represents another discharge point for the shallow reservoir. However, a longer lateral flow path from the reservoir, conductive heat loss, mixing with cold water, and low flow rates and/or relatively low volume discharge allow for cooling and dilution of the thermal solution. 


\section{SUMMARY AND CONCLUSIONS}

1) The thermal discharges at all three hot springs are dilute, slightly alkaline to alkaline, sodium bicarbonate $\left(\mathrm{NaHCO}_{3}\right)$ waters. The highest concentrations of total dissolved solids occur at Alvord Hot Springs and the lowest concentrations at Mickey Springs. The high total dissolved solids at Alvord Hot Springs are consistent with conductive cooling of a He- and Cl-rich fluid during ascent, or concentration of non-volatile constituents during cooling by gentle boiling.

2) Thermal waters originate in a hot-water system rather than a vapor-dominated system. The occurrence of high concentrations of boron, silica, arsenic and chloride support this conclusion. Fairly high ratios of $\mathrm{Cl} / \mathrm{Mg}, \mathrm{Ca} / \mathrm{Mg}$ and low ratios of $\mathrm{Ca} / \mathrm{Na}$ are typical of hydrothermal systems having moderately high temperatures.

3) Calculated reservoir temperatures based on chemical and isotope geothermometers are similar for the three hot spring areas. The reservoir temperatures are estimated to be between 170 and $200^{\circ} \mathrm{C}$. Oxygen isotope geothermometers for coexisting water and dissolved sulfate indicate reservoir temperatures between 198 and $207^{\circ} \mathrm{C}$ at Alvord Hot Springs and Borax Lake. Mickey Springs and a flowing well at Borax Lake yield temperatures of 150 and $168^{\circ} \mathrm{C}$, 
respectively. These values may indicate partial

reequilibration of the isotopic system by near-surface mixing with a different sulfate-bearing water.

4) Tritium concentrations indicate long residence times for the thermal water discharging from all three springs. The two end-member models used for the calculation of residence times generate a minimum of 57 years and a maximum of greater than 10,000 years.

5) The $\delta D$ values indicate the source recharge to the geothermal system is meteoric water, primarily from steens Mountain-Pueblo Mountains. Thermal fluids have the same $\delta D$ composition as cold groundwater and surface water. The $\delta^{18} \mathrm{O}$ enrichment of 2-3 $0 / 00$ to the right of the meteoric water line is consistent with fluid-rock interactions in the reservoir.

6) The $\mathrm{N}_{2} / \mathrm{Ar}$ ratios of gas discharges from all three sites indicate recharge by air-saturated ground water. The relative concentrations of $\mathrm{He}, \mathrm{N}_{2}$ and $\mathrm{Ar}$ indicate longer fluid residence times for Alvord Hot Springs thermal fluids. Lower concentrations of He and Ar at Mickey Springs suggest more steam is released by vigorous boiling. Low concentrations of $\mathrm{H}_{2} \mathrm{~S}, \mathrm{CH}_{4}$ and $\mathrm{H}_{2}$ support the conclusion that oxidation is a major process in these geothermal systems. The $\delta^{13} \mathrm{C}$ compositions of $\mathrm{CO}_{2}$ and $\mathrm{CH}_{4}$ are similar to values for other geothermal systems. The $\delta^{13} \mathrm{C}$ values of $\mathrm{CO}_{2}$ are believed to reflect atmospheric values. Carbon isotopes 
from methane indicate "normal" geothermal methane for Alvord Hot Springs and Mickey Springs, but a smail contribution of thermogenic methane is indicated for the hot springs north of Borax Lake.

7) Conservative element ratios ( $B / C I)$ indicate the geothermal reservoir is hosted in volcanic rocks. The Li/Cs ratios for the Borax Lake thermal area are consistent with a reservoir located in rhyolitic rocks. Radium isotope ratios analysis indicates interactions with volcanic rocks for Borax Lake. These ratios for thermal fluids from Alvord Hot Springs and Mickey Springs are lower than those expected for volcanic rocks and may indicate local uranium accumulation in the reservoir or zones of upflow. Strontium isotope ratios for thermal waters are similar to those of volcanic rocks stratigraphically below the Steens Basalt. These formations include the Steens Mountain Volcanics, Pike Creek Formation, and Alvord Creek Formations.

8) Data obtained in this study do not preclude a single large reservoir system discharging at the three thermal areas in the Alvord basin. Differences in the chemical composition of discharge from the three springs is produced during upflow from the reservoir. During upflow, thermal waters follow a complex pathway of fractures and reside in shallow reservoirs before reaching the surface. Boiling, mixing with condensate, oxidation, mixing with 1-3\% tritiumbearing, near-surface water, relative differences in flow 
rate and volume, and conductive heat loss are processes that modify fluid composition during upflow from a deep geothermal reservoir. 


\section{REFERENCES}

Baldwin, E.M., 1976, Geology of Oregon (revised ed.): Dubuque, Iowa, Kendall/Hunt, 147 p.

Barrash, W., and Venkatakrishnan, R., 1982, Timing of late Cenozoic volcanic and tectonic events along the western margin of the North American plate: Geological Society of America Bulletin, v. 93, p. 977-989.

Benjamin, T., Charles, R., and Vidale, R., 1983, Thermodynamic parameters and experimental data for the Na-K-Ca geothermometer: Journal of Volcanology and Geothermal Resources, v. 15, p. 167-186.

Blackwell, D.D., 1983, Heat flow in the northern Basin and Range province: Geothermal Resources Council Special Report, no. 13, p. 81-92.

Blackwell, D.D., Hull, D.A., Bowen, R.G., and Steele, J.L., 1978, Heat flow of Oregon: Oregon Department of Geology and Mineral Industries Special Paper, v. $4,42 \mathrm{p}$.

Blackwell, D.D., Kelley, S.A., and Edmiston, R.C., 1986, Analyis and interpretation of thermal data from Borax Lake geothermal prospect, Oregon: Geothermal Resources Council Transactions, v. 10, p. 169-174.

Bodvarsson, G.S., 1991, Affadavit of Gudmundur S. Bodvarsson in support of response of Anadarko Petroleum Corporation to appellant's statement of reasons: Bureau of Land Management, Internal Board of Land Appeals, IBLA 91-158.

Bodvarsson, G.S., 1992, Second supplemental declaration of Dr. G. Bodvarsson: Bureau of Land Management, Internal Board of Land Appeals, IBLA 91-158. 
Brown, D.E., and Peterson, N.V., 1980, Preliminary geology and geothermal resource potential of the Alvord Desert area, Oregon: Oregon Department of Geology and Mineral Industries Open-File Report 0-80-10.

Carlson, R.W., and Hart, W.K., 1987, Crustal genesis on the Oregon Plateau: Journal of Geophysical Research, v. 92, p. 6191-6206.

Campana, M.E., Jacobson, R.L., and Ingraham, N.L., 1980, Chapter 6, Shallow temperature survey, in Geothermal resource assessment case study, northern Basin and Range province, northern Dixie Valley, Nevada: Reno, Nevada, University of Nevada, Mackay Minerals Resource Institute, p. 187-205.

Catching, R.D., 1990, Seismic implications for crustal composition and deformation along the Basin and Range/Cascade Range boundary (abstract): EOS Transactions, American Geophysical Union, v. 71, p. 1613 .

Christiansen, R.L., and McKee, E.H., 1978, Late Cenozoic volcanic and tectonic evolution of the Great Basin and Columbia Intermontane region: Geological Society of America Memoir 152, p. 283-311.

Clark, J.F., and Turekian, K.K., 1990, Time scale of hydrothermal water-rock reactions in Yellowstone National Park based on radium isotopes and radon: Journal of Volcanology and Geothermal Research, v. 40 , p. 169-180.

Cleary, J., 1976, Geothermal investigation of the Alvord Valley, southeast Oregon: Missoula, Montana, University of Montana, unpublished Master's Thesis, $71 \mathrm{p}$.

Craig, H., 1953, The geochemistry of carbon stable isotopes: Geochimica et Cosmochimica Acta, v. 3, p. 53-92.

Craig, H., 1961, Isotopic variations in meteoric waters: Science, v. 133, p. 1702-1703.

Craig, H., Boato, G., and White, D.E., 1956, Isotopic geochemistry of thermal waters: National Academy of Sciences Research Council Publications, v. 400, p. 29-38. 
Cummings, M.L. and St. John, A.M., 1993, Hydrogeochemical characterization of the Alvord Valley Known Geothermal Resources Area (KGRA), Harney County, Oregon: Report prepared for Bonneville Power Administration, Procurement No. De-PR79-91BP19408 and Modification No. A001.

D'Amore, F., and Panichi, C., 1980, Evaluation of deep temperature of hydrothermal systems by a new gas geothermometer: Geochimica et Cosmochimica Acta, v. 44, p. 549-556.

Deines, P., 1980, The isotopic composition of reduced organic carbon, in Fritz, P. and Fontes, J. Ch., eds., Handbook of environmental and isotope geochemistry, Volume 1: Amsterdam, Elsevier Publishing Company, p. 329-406.

Eaton, G.P., 1982, The Basin and Range province: Origin and tectonic significance: Annual Review of Earth and Planetary Science Letters, v. 10, p. 409-440.

Eddington, P.K., Smith, R.B., and Renggli, 1987, Kinematics of Basin and Range intraplate extension, in Coward, M.P., Dewy, J.F., and Hancock, P.L., eds., Continental Extensional Tectonics, Geological

Society of America Special Publication, v. 28, p. 371-392.

Ellis, A.J., 1970, Quantitative interpretation of chemical characteristics of geothermal systems: Geothermics, v.2, p. 516-528.

Ellis, A.J., 1979, Explored geothermal systems, in H.L. Barnes, ed. , Geochemistry of hydrothermal ore deposits: New York, John Wiley and Sons, p. 632683.

Ellis, A.J., and Mahon, W.A.J., 1964, Natural hydrothermal systems and experimental hot-water/rock interactions: Geochimica et Cosmochimica Acta, v. 28 , p. 1323-1357.

Ellis, A.J., and Mahon, W.A.J., 1967, Natural hydrothermal systems and experimental hot-water/rock interactions (Part II): Geochimica et Cosmochimica Acta, v. 31, p. 519-539.

Ellis, A.J., and Mahon, W.A.J., 1977, Chemistry and geothermal systems: New York, Academic Press, 392 p. 
Eugster, H.P., and Jones, B.F., 1979, Behavior of major solutes during closed-basin brine evolution: American Journal of Science, v. 279, p. 609-631.

Faure, G., 1991, Principles and applications of inorganic geochemistry: New York, Macmillan Publishing Company, $626 \mathrm{p}$.

Fontes, J.Ch., 1980, Environmental isotopes in groundwater hydrology, in Fritz, P. and Fontes, J. Ch., eds., Handbook of environmental isotope geochemistry, v. 1A: The terrestrial environment: Amsterdam, Elsevier Publishing Company, p. 75-140.

Fournier, R.O., 1970, Silica in thermal water: Laboratory and field investigations, in Proceedings of the International Symposium on Hydrogeochemistry and Biogeochemistry Japan, Volume 1: Washington, D.C., The Clark Company, p. 122-139.

Fournier, R.O., 1979a, A revised equation for the $\mathrm{Na} / \mathrm{K}$ geothermometer: Geothermal Resources Council Transactions, v. 3, p. 221-224.

Fournier, R.O., 1979b, Geochemical and hydrological considerations and the use of enthalpy-chloride diagrams in the prediction of underground conditions in hot-spring systems: Journal of Volcanology and Geothermal Research, v. 5, p. 116.

Fournier, R.O., 1981, Application of water chemistry to geothermal exploration and reservoir engineering, In, Rybach, L., and Muffler, L.J.P., eds., Geothermal Systems: Principles and case histories: New York, Wiley, p. 109-143.

Fournier, R.O., and Hanshaw, B.B., 1986, Geochemical evaluation of the geothermal resources in the San Marcos region, Guatemala: Applied Geochemistry, v. 1, pp. 189-197.

Fournier, R.O., and Rowe, J.J., 1966, Estimation of underground temperatures from the silica content of water from hot springs and wet-steam wells: American Journal of Science, v. 264, p. 685-697. 
Fournier, R.O., and Truesdell, A.H., 1970, Chemical indicators of subsurface temperature applied to hot spring waters of Yellowstone Nationai Park, Wyoming, U.S.A., in U.N. Symposium on Development and Utilization of Geothermal Resources, Pisa, 1970: Geothermics, Special Issue 2, p. 529-5

Fournier, R.O., and Truesdell, A.H., 1973, An empirical Na$\mathrm{K}$-Ca geothermometer for natural waters: Geochimica et Cosmochimica Acta, v. 37, p. 12551275 .

Fournier, R.O., and Truesdell, A.H., 1974, Geochemical indicators of subsurface temperature, Part 2. Estimation of temperature and fraction of hot water mixed with cold water: U.S. Geological Survey Journal of Research, v. 2, p. 263-270.

Fournier, R.O., White, D.E., and Truesdell, A.H., 1974, Geochemical indicators of subsurface temperatures: Part 1. Basic assumptions: Journal of Research of the U.S. Geological Survey, v. 2, p. 259-262.

Fuller, R.E., 1931, The geomorphology and volcanic sequence of Steens Mountain in southeastern Oregon: University of Washington Publications in Geology, v. 3 , no. 1 .

Giggenbach, W.F., 1980, Geothermal gas equilibria: Geochimica et Cosmochimica Acta, v. 44, p. 20212032 .

Giggenbach, W.F., 1986, The use of gas geochemistry in delineating the origin of fluids discharged over the Taupo Volcanic Zone: Proceedings of the 5 th International Volcanologists Congress, Aukland, New Zealand, p. 47-50.

Giggenbach, W.F., 1987, Carbon-13 exchange between $\mathrm{CO}_{2}$ and $\mathrm{CH}_{4}$ under geothermal conditions: Geochimica et Cosmochimica Acta, v. 46, p. 159-165.

Giggenbach, W.F., 1988, GeothermaI solute equilibria. Derivation of $\mathrm{Na}-\mathrm{K}-\mathrm{Mg}-\mathrm{Ca}$ geoindicators: Geochimica et Cosmochimica Acta, v. 52, p. 27492765. 
Giggenbach, W.F., and Goguel, R.L., 1989a, Methods for the collection and analysis of geothermal and volcanic water and gas samples: Petone, New Zealand, Chemistry Division, Department of Scientific and Industrial Research, Report 2401, p. 1-53.

Giggenbach, W.F., and Goguel, R.L., 1989b, Techniques for the interpretation of water and gas analyses in geothermal exploration: Petone, New Zealand, Chemistry Division, Department of Scientific and Industrial Research, Report 2401, p. 55-81.

Giggenbach, W.F., Garcia P., N., Londono C., A., Rodriguez V., L.A., Rojas G., N., and Calvache V., M.L.,, 1990, The chemistry of fumarolic vapor and thermal-spring discharges from the Nevado del Ruiz volcanic-magmatic-hydrothermal system, Columbia: Journal of Volcanology and Geothermal Research, v. 42 , p. 13-39.

Goff, F., Truesdell, A.H., Grigsby, C.O., Janik, C.J., Shevenell, L.A., Paredes, J.R., Guitierrez, J.W., Trujillo, P.E., Jr., and Counce, D.A., 1987, Hydrogeochemical investigation of six geothermal sites in Honduras, Central America: Los Alamos, New Mexico, Los Alamos National Laboratory, Publication no. LA-10785-MS, 170 p.

Goff, F., Goff, S.J., Kelkar, S., Shevenall, L., Truesdell, A.H., Musgrave, J., Rufenacht, H., and Flores, W., 1991a, Exploration drilling and reservoir model of the Platanares geothermal system, Honduras, C.A.: Journal of Volcanology and Geothermal Research, v. 45 , p. 101-123.

Goff, F., Wollenberg, H.A., Brookins, D.G., and Kistler, R.W, 1991b, A Sr-isotope comparison between thermal waters, rocks and hydrothermal calcites, Long Valley caldera, California: Journal of Volcanology and Geothermal Research, v. 48, p. 265-281.

Goldstein, M.A., Strangway, D.W., and Larson, E.E., 1969, Paleomagnetism of a Miocene transition zone in southeastern Oregon: Earth and Planetary Science Letters, v. 7, p. 231-239.

Graham, I.J., 1992, Strontium isotope composition of Rotorua geothermal waters: Geothermics, v. 21, p. 165-180. 
Griscom, A., and Conradi, A., Jr., 1975, Principal facts and preliminary interpretation for gravity profiles and continuous truck-mounted magnetometer profiles in the Alvord Valley, Oregon: U.S. Geological Survey Open-File Report 75-293, 20 p.

Gunn, B.M., and Watkins, N.D., 1970, Geochemistry of the Steens Mountain basalts, Oregon: Geological

Society of America Bulletin, v. 81, p. 1497-1516.

Hart, W.K., and Mertzman, S.A., 1982, K-Ar dates of basalts from southcentral Oregon: Isochron/West, no. 33, p. 23-26.

Hart, W.K., and Carlson, R.W., 1985, Distribution and geochronology of Steens Mountain-type basalts from the northwestern Great Basin: Isochron/West, v.43, p. 5-10.

Hart, W.K, and Carlson, R.W., 1987, Tectonic controls on magma genesis and evolution in the northwestern United States: Journal of Volcanology and Geothermal Research, v. 32, p. 119-135.

Hart, W.K., Carlson, R.W., and Mosher, S.A., 1989, Petrogenesis of the Pueblo Mountains basalt, southeastern Oregon and northern Nevada: Geological Society of America Special Paper 239, p. 367-378.

Hemphill-Haley, M.A., 1987, Quaternary stratigraphy and late Holocene faulting along the base of the eastern escarpment of Steens Mountain, southeastern Oregon: Arcata, California, Humboldt State University, Unpublished Master's thesis, , $87 \mathrm{p}$.

Hemphill-Haley, M.A., Page, W.D., Burke, R., and Carver, G.A.,1989, Holocene activity of the Alvord fault, Steens Mountain, southeastern Oregon: Final Report to the U.S. Geological Survey under Grant No. 1408-0001-G1333, Woodward-Clyde Consultants, Oakland, California, $45 \mathrm{p}$.

Henley, R.W., and Ellis, A.J., 1983, Geothermal systems ancient and modern: A geochemical review: Earth and Planetary Science Reviews, v. 19, p. 1-50.

Henley, R.W., Truesdell, A.H., and Barton, P.B., Jr., 1984, Fluid-mineral equilibria in hydrothermal systems: Reviews in Economic Geology, Vol. 1: Chelsea, MI, Society of Economic Geologists, 267 p. 
Hoefs, J., 1987, Stable isotope geochemistry, 3rd Edition: Berlin, Springer-Verlag, 241 p.

Holt, B.D., 1977, Preparation of carbon dioxide from sulfates, sulfur dioxide, air, and water for determination of oxygen isotope ratio: Analytical Chemistry, v. 49, p. 1664-1667.

Hook, R., 1981, The volcanic stratigraphy of the Mickey Hot Springs area, Harney County, Oregon: Oregon State University, unpublished Master's Thesis, 66 p.

Huntley, D., 1991, Affadavit of David Huntley in support of response of Sierra Club, Inc. statement of reasons: Bureau of Land Management, Internal Board of Land Appeals, IBLA 91-158, OR-EA-020-25.

Huntley, D., 1992, Second supplemental declaration of David Huntley in support of response of Sierra Club, Inc. statement of reasons: Bureau of Land Management, Internal Board of Land Appeals, IBLA 91-158, OR-EA-020-25.

Kharaka, Y.K., and Mariner, R.H., 1989, Chemical geothermometers and their application to formation waters from sedimentary basins, in Nesser, N.D., and McCulloh, eds., Thermal history of Sedimentary basins: Methods and case histories, SpringerVerlag, N.Y., p. 99-117.

Kharaka, Y.K., Gunter, W.D., Aggarwal, P.K., Perkins, E.H., and DeBraal, J.D., 1988, SOLMINEQ.88: A computer program for geochemical modeling of water-rock interactions: U.S. Geological Survey WaterResources Investigations Report, 88-4227, 420 p.

Kharaka, Y.K., Mariner, R.H., Ambata, G., Evans, W.C., White, L.D., Bullen, T.D., and Kennedy, B.M., 1990, Origins of water and solutes in and north of the Norris-Mammoth Corridor, Yellowstone National Park: Geothermal Resources Council Transactions, v. 14, p. 705-714.

Langer, V.W., 1991, Geology and petrologic evolution of silicic and intermediate volcanic rocks underneath Steens Mountain Basalt, SE Oregon: Corvallis, Oregon, Oregon State University, unpublished Master's Thesis, 109 p.

Lawrence, R.D., 1976, Strike-slip faulting terminates the Basin and Range province in Oregon: Geological Society of America Bulletin, v. 87, p. 846-850. 
Libbey, F.W., 1960, Boron in Alvord Valley, Harney County, Oregon: Oregon Department of Geology and Mineral Industries, The Ore-Bin, v. 22, p. 97-105.

Long, C.L., and Gregory, D.I., 1975, Audio-magnetotelluric apparent resistivity maps for part of Harney County, Oregon: U.S. Geological Survey Open-File Report 75-297, 5 plates.

Mankinen, E.A., Larson, E.E., Gromme, C.S., Prevot, M. and Coe, R.S., 1987, The Steens Mountain (Oregon) geomagnetic polarity transition. 3. Its regional significance: Journal of Geophysical Research, v. 92 , p. 8057-8076.

Mariner, R.H., Presser, T.S., and Evans, W.C., 1983, Geochemistry of active geothermal systems in the northern Basin and Range province: Geothermal Resources Council Special Report no. 13, p. 95119 .

Mariner, R.H., Brook, C.A., Swanson, J.R., and Mabey, D.R., 1980, Chemical and isotopic data for thermal springs and wells of Oregon: U.S. Geological Survey Open-file Report 80-737, 50 p.

Mariner, R.H., Rapp, J.B., Willey, L.M., and Presser, T.S., 1974, Chemical composition and estimated minimum thermal reservoir temperatures of selected hot springs in Oregon: U.S. Geological Survey, Openfile Report, 32 p.

McKenzie, w.F. and Truesdell, A.H., 1977, Geothermai reservoir temperatures estimated from the oxygen isotope compositions of dissolved sulfate and water from hot springs and shallow drill holes: Geothermics, v. 5, p. 51-62.

Michael, R.L., 1989, Tritium deposition in the continental United States, 1953-1983: U.S. Geological Survey Water Resources Investigations Report 89-4072, 46 p.

Michels, D.E., 1991, A heat/mass/solute balance model for Borax Lake, a geothermal feature of the Pueblo Valley, Oregon: Geothermal Resources Council Transactions, v. 15, p. 265-272.

Mifflan, M.D., 1968, Delineation of ground-water flow systems in Nevada: Desert Research Institute Technical Report Series H-W, no. 4, 111 p. 
Mifflan, M.D., 1988, Region 5, Great Basin, in Back, W., Rosenshein, J.S., and Seaber, P.R., eds., Hydrogeology: Boulder, Colorado, Geological Society of America, The Geology of North America, v. $0-2$, p. 69-78.

Minor, S.A., Plouff, D., Esparza, L.E., and Peters, T.J., 1987a, Mineral resources of the High Steens and Little Blitzen Gorge Wilderness Study Area, Harney County, Oregon: U.S. Geological Survey Bulletin (Washington), Report no. B 1740-A, p. A1-A21.

Minor, S.A., Rytuba, J.J., Grubenshy, M.J., Vander Meulen, D.B., Goeldner, C.A., and Tegtmeyer, K.J., 1987b, Geologic map of the High Steens and Little Blitzen Gorge Wilderness Study Area, Harney County, Oregon: U.S. Geological Survey Miscellaneous Field Studies Map MF-1876, scale 1:24,000.

Minor, S.A., Rytuba, J.J., Goeldner, C.A., and Tegtmeyer, H.J., 1987c, Geologic Map of the Alvord Hot Springs Quadrangle, Harney County, Oregon: U.S. Geological Survey Miscellaneous Field Studies Map MF-1915, scale 1:24,000.

Notsu, R., Wakita, H., Nakamura, Y., 1991, Strontium isotopic compositions of hot spring and mineral spring waters: Applied Geochemistry, v. 6, p. 543551 .

Norman, D.I., and Bernhardt, C.A., 1981, Assessment of geothermal reservoirs by analysis of gases in thermal waters: Final Technical Report, New Mexico Energy Institute, New Mexico State University, Las Cruces, New Mexico, $130 \mathrm{p}$.

Olmsted, F.H., Welch, A.H., Van Denburgh, A.S., and Ingebritsen, S.E., 1984, Geohydrology, aqueous geochemistry, and thermal regime of the Soda Lakes and Upsal Hogback geothermal systems, Churchill County, Nevada: U.S. Geological Survay WaterResources Investigations Report 84-4054, 166 p.

Orr, E.L., Orr, W.N., and Baldwin, E.M., Geology of Oregon (Fourth Edition): Dubuque, Iowa, Kendall/Hunt Publishing Company, 254 p. 
Ostlund, H.G., and Dorsey, H.G., 1975, Rapid electrolytic enrichment and hydrogen gas proportional counting for tritium, in: P. Povinec and S. Usacev, eds., Low radioactivity measurements and applications, Proceedings of the International Conference, The High Tatras, CSSR, 6-10 October 1975, Bratislava Slovenske' Pedagogicke' Nakladatelstvo, 542 p.

Palmer, M.R., and Sturchio, N.C., 1990, The boron isotope systematics of the Yellowstone National Park (Wyoming) hydrothermal system: A reconnaissance: Geochimica et Cosmochimica Acta, v. 54, p. 28112815 .

Pampura, V.D., Plyusnin, G.S., and Sandimirova, G.P., 1980, Geochemical and isotopic composition of strontium in mineral forming solutions of the Pauzhetka hydrothermal system (Southern Kamchatka): Geokhimiya, v. 1, p. 122-135.

Parry, W.T., and Bowman, J.R., 1990, Chemical and stable isotopic models for Boundary Creek warm springs, southwestern Yellowstone National Park, Wyoming: Journal of Volcanology and Geothermal Resources, v. 43, p. 133-157.

Pearson, F.J., and Truesdell, A.H., 1978, Tritium in waters of Yellowstone National Park: U.S. Geological Survey Open-file Report 78-701.

Piper, A.M., Robinson, T.W., and Park, C.F., Jr., 1939, Geology and ground-water resources of Harney Valley, Oregon: U.S. Geological Survey WaterSupply Paper 841, 189 p.

Presser, T.S., and Barnes, I., 1974, Special techniques for determining chemical properties of geothermal water: U.S. Geological Survey Water Resources Investigations $22-74,15 \mathrm{p}$.

Roper, M. W., and Wallace, A. B., 1981, Geology of the Aurora uranium prospect, Malheur County, Oregon, in Goodell, P.C. and Waters, A.C. (editors), Uranium in Volcanic and Volcaniclastic Rocks: American Association of Petroleum Geologists Studies in Geology 13, p. 81-88.

Ross, C. P., 1942, Quicksilver deposits in the steens and Pueblo Mountains southern Oregon: U.S. Geological Survey Bulletin 931-J, p. 227-258. 
Russell, I.C., 1885, Geological history of Lake Lahonton: U.S. Geological Survey Monograph 11, 288 p.

Rytuba, J.J., and Conrad, W.K., 1981, Petrochemical characteristics of volcanic rocks associated with uranium deposits in the McDermitt caldera complex: Studies in Geology, Tulsa, Oklahoma, v. 8., p. 63-72.

Rytuba, J.J., and McKee, E.H., 1984, Peralkaline ash flow tuffs and calderas of the McDermitt volcanic field, southeast Oregon and northcentral Nevada: Journal of Geophysical Research, v. 89, p. 8616-8628.

Sammell, E.A. and Craig, R.W., 1981, The geothermal hydrology of Warner Valley, Oregon: A reconnaissance study: U.S. Geological Survey Professional Paper 1044-I, 47 p.

Sass, J.H., Blackwell, D.D., Chapman, D.S., Costain, J.K., Decker, E.R., Lawver, L.A., and Swanberg, C.A., 1981, Heat flow from the crust of the United States, in Toulaukian, Y.S., Judd, W.R., and RoY, R.F., eds., Physical properties of rocks and minerals, Vol. II-2: McGraw-Hill, New York, p. 503-548.

Sheppard, S.M.F., 1986, Characterization and isotopic variations in natural waters, in Valley, J.W., Taylor, H.P., Jr., and O'Neill, J.R., eds., Stable isotopes in high temperature geological processes: Washington, D.C., Mineralogical Society of America, p. 165-183.

Shevenell, L., 1990, Chemical and isotopic investigation of the new hydrothermal system at Mount St. Helens, Washington: University of Nevada, Reno, Nevada, unpublished Ph.D., 282 pp.

Shevenell, L., 1991, Tritium in thermal waters discharging in Loowit Canyon, Mount St. Helens, Washington, U.S.A.: Chemical Geology (Isotope Geoscience Section), v. 94, p. 123-135.

Shevenell, L., Goff, F., Grigsby, C.O., Janik, C.J., Trujillo, P.E., and Counce, D., 1987, Chemical and isotopic characteristics of thermal fluids in the Long Valley caldera lateral flow system, California: Geothermal Resources Council Transactions, v. 11, p. 195-201. 
Sorey, M.L., Suemnicht, G.A., Sturchio, N.C., and Nordquist, G.A., 1991, New evidence on the hydrothermal system in Long Valley caldera, California, from wells, fluid sampling, electrical geophysics, and age determinations of hot-spring deposits: Journal of Volcanology and Geothermal Research, v. 48 , p. 229-263.

Stewart, M.K., Lyon, G.L., Robinson, B.W., and Glover, R.B., 1992, Fluid flow in the Rotorua geothermal field derived from chemical and isotopic data: Geothermics, v. 21, p. 141-163.

Sturchio, N.C., 1990, Radium isotopes, alkaline earth diagenesis, and age determination of travertine from Mammoth Hot Springs, Wyoming, U.S.A.: Applied Geochemistry, v. 5, p.631-640.

Sturchio, N.C. and Binz, C.M, 1988, Uranium-series age determination of calcite veins, VC-1 drill core, Valles caldera, New Mexico: Journal of Geophysical Research, v. 93, p. 6097-6102.

Sturchio, N.C., Bohlke, J.K., and Markun, F.J., 1993, Radium isotope geochemistry of thermal waters, Yellowstone National Park, Wyoming: Geochimica et Cosmochimica Acta, v. 57, p. 1203-1214.

Swanberg, C.A., 1979, Chemistry of thermal and nonthermal waters in the Rio Grande rift and adjacent tectonic provinces, in Reicker, R.E., ed., Rio Grande Rift: Tectonics and magmatism: American Geophysical Union, Washington, D.C., p. 279-288.

Swanberg, C.A., and Alexander, S., 1979, Use of water quality file WATSTORE in geothermal exploration: An example from the Imperial Valley, California: Geology, v. 7, p. 198-211.

Taylor, C.B. and Stewart, M.K., 1987, Hydrology of Rotorua geothermal aquifer, in Isotope techniques in water resources development: Vienna, Austria, IAEA-SM $299 / 95$, p. 25-45.

Taylor, H.P., 1974, The application of hydrogen and oxygen isotopes to problems of hydrothermal alteration and ore deposition: Economic Geology, v. 68, p. 843-883. 
Thompson, J.M., 1975, Selecting and collecting thermal springs for chemical analysis: A method for field personnel: U.S. Geological Survey Open-File Report 75-76, $11 \mathrm{p}$.

Townley, P.J., Soja, C.M., and Sidle, W.C., 1980, Groundwater data for the Riley and Andrews Resource Areas, southeastern Oregon: U.S. Geological Survey Open-File Report 80-419, 32 p.

Truesdell, A.H., 1976, Geochemical techniques in exploration, summary of section III, Proceedings of the Second United Nations Symposium on the Development and Use of Geothermal Resources, San Francisco, Vol. 1: Berkeley, California, University of California, p. 53-78.

Truesdell, A.H., 1985, Introduction to chemical calculations, in Robertson, J.M., ed., Fluidmineral equilibria in hydrothermal systems, Reviews in economic geology, volume 1: Chelsea, Michigan, Society of Economic Geologists, p. 1-8.

Truesdell, A.H., and Hulston, J.R., 1980, Isotopic evidence on environments of geothermal systems, in Fritz, P., and Fontes, J.Ch., eds., Handbook of environmental isotope geochemistry: New York, Elsevier Scientific Publishing, p. 179-226.

Turi, B., 1986, Stable isotope geochemistry of travertines, in Fritz, P., ed., Handbook of environmental geochemistry - B, The terrestrial environment: Amsterdam, The Netherlands, p.207-238.

Varekamp, J.C., and Buseck, P.R., 1983, Hg anomalies in soils: A geochemical exploration method for geothermal areas: Geothermics, v. 12, p. 29-47.

Vuataz, F.D., and Goff, F., 1986, Isotope geochemistry of thermal and nonthermal waters in the Valles Caldera, Jemez Mountains, New Mexico: Journal of Geophysical Research, v. 91, p.1835-1853.

Vuataz, F.D., Goff, F., Fouillac, C., and Calvey, J-Y., 1988, A strontium isotope study of VC-1 core and associated hydrothermal fluids and rocks from Valles Caldera, Inez Mountains, New Mexico: Journal of Geophysical Research, v. 93 (B6), p. 6059-6067. 
Walker, G.W. and Repenning, C.A., 1965, Reconnaissance geologic map of the Adel quadrangle, Lake, Harney and Malheur Counties, Oregon: U.S. Geological Survey Map, I-446, scale 1:250,000.

Wallace, A. B., and Roper, M. W., 1981, Geology and uranium deposits along the northeastern margin, MCDermitt caldera complex, Oregon, in Goodell, P.C. and Waters, A.C., eds., Uranium in Volcanic and Volcaniclastic Rocks: American Association of Petroleum Geologists Studies in Geology 13, p.7379

Watkins, N.D., 1965, Frequency of extrusions of some Miocene lavas in Oregon during an apparent transition of the polarity of the geomagnetic field: Nature, $v$. 206, p. 801-803.

Watkins, N.D., 1969, Non-dipole behavior during an upper Miocene geomagnetic polarity transition in Oregon: Geophysical Journal of the Royal Astronomical Society, v. 17, p. 121-149.

Watkins, N.D., and Baksi, A.K., 1974, Magnetostratigraphy and oroclinal folding of the Columbia River, Steens and Owyhee basalts in Oregon, Washington, and Idaho: American Journal of Science, v. 274, p. 148-189.

Welch, A.H., and Preissler, A.M., 1987, Geothermal resources of the western arm of the Black Rock Desert, northwestern Nevada: Part II, Aqueous Geochemistry and hydrology: U.S. Geological Survey WaterResources Investigations Report 87-4062, 90 p.

White, A.F., Peterson, M.L., Wollenberg, H., and Flexser, S., 1990, Sources and fractionation processes influencing the distribution of $\mathrm{D},{ }^{18} \mathrm{O}$, and ${ }^{13} \mathrm{C}$ in the Long valley hydrothermal system California, USA: Applied Geochemistry, v. 5, p. 571-585.

White, D.E., 1965, Saline waters of sedimentary rocks, in Young, A. and Galley, G.E., eds., Fluids in subsurface environments, American Association of Petroleum Geologists Memoir 4, p. 342-366.

White, D.E., 1970, Geochemistry applied to the discovery, evaluation, and exploitation of geothermal energy resources: Rapporteur's Report, in Proceedings, United Nations Symposium on the Development and Utilization of Geothermal Resources, Piza, 1970: Geothermics Special Issue 2, v. 1, p. 58-80. 
White, D.E., and Williams, D.L, 1975, Assessment of geothermal resources of the United States, 1975: U.S. Geological Survey Circular, v. 790, 155 p.

Whiticar, M.J., 1990, A geochemical perspective of natural gas and atmospheric methane: Advances in Organic Geochemistry, v. 16, p. 531-547.

Wilkerson, W.L., 1958, The geology of a portion of the southern Steens Mountains, Oregon: Eugene, Oregon, University of Oregon, unpublished Master's Thesis.

Williams, H., and Compton, R.R., 1953, Quicksilver deposits of the Steens Mountain and Pueblo Mountains, southeast oregon: U.S. Geological Survey Bulletin 995-B, p. 19-77.

Wood, W.W., 1976, Guidelines for collection and field analysis of ground-water samples for selected unstable constituents: U.S. Geological Survey Techniques of Water-Resources Investigations Book 1, Chapter D2, 24 p.

Zoback, M.L., and Thompson, G.A., 1978, Basin and Range rifting in northern Nevada, clues from a midMiocene rift and its subsequent offsets: Geology, v. 6 , p. 111-116.

Zoltai, T. and Stout, J. H., 1984, Mineralogy Concepts and Principles: Burgess Publishing Company, Minneapolis, Minnesota, 505 p. 
APPENDIX

HYDROGEOCHEMICAL DATA 
TABLE XIV

CHEMISTRY OF THERMAL AND NON-THERMAL WATER
IN THE ALVORD BASIN, $1953-1989$

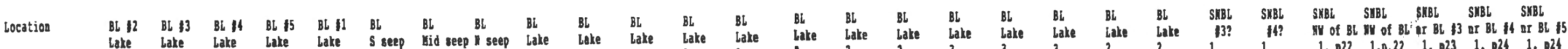

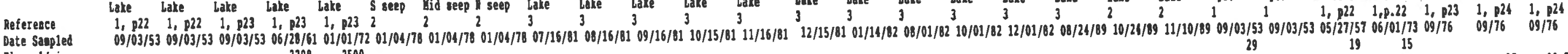

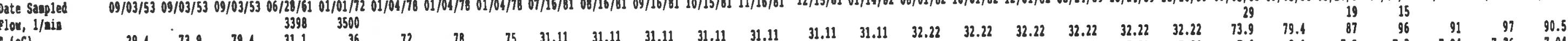

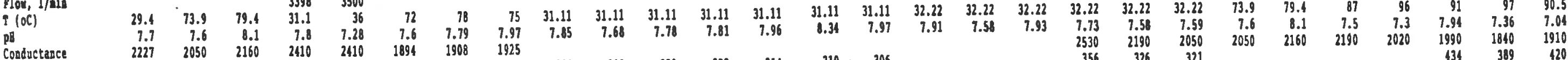

1lkainst

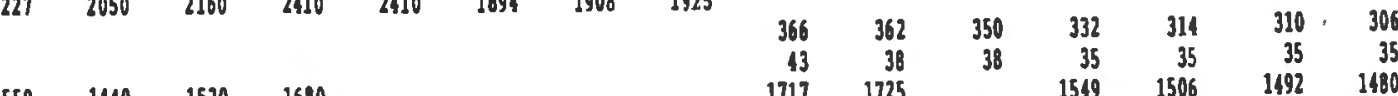

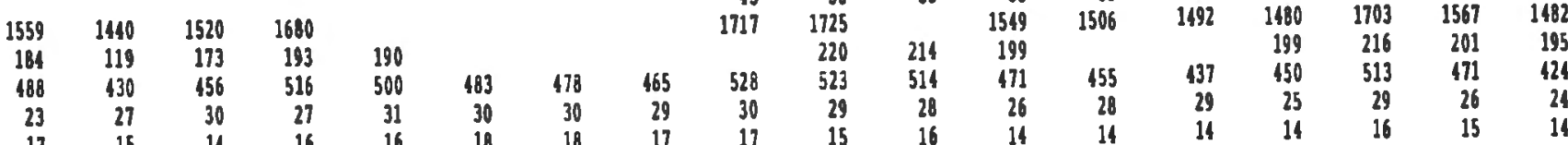

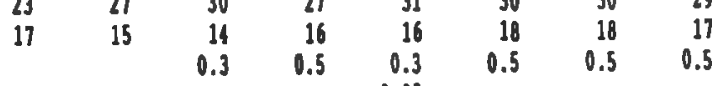

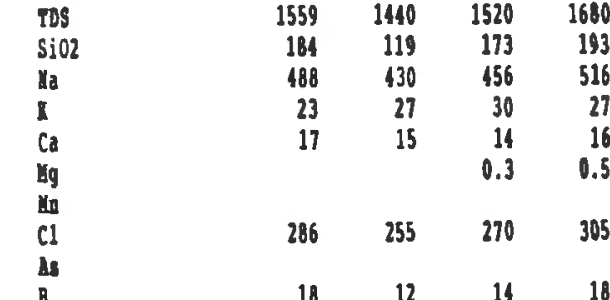

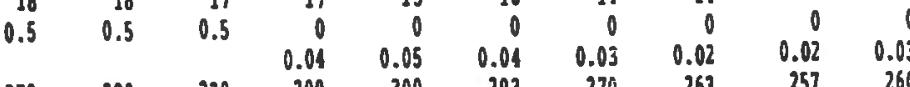

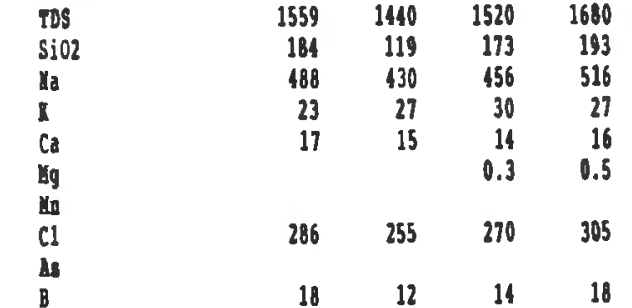

$\begin{array}{rrrrrrrr} & & 220 & 300 & 300 & 293 & 270 & 2.03 \\ 16.1 & 16.2 & 15.8 & 1.53 & 1.46 & 1.36 & 1.255 & 1.2 .2 \\ & 16.5 & 16.2 & 14.5 & 14 .\end{array}$

$\begin{array}{rrr}2530 & 2190 & 2050 \\ 356 & 326 & 321 \\ 40.5 & 38 & 38.9\end{array}$

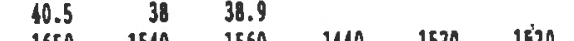

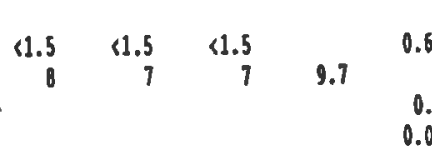

$\begin{array}{lll}17.1 & 16\end{array}$

$\begin{array}{rrr}495 & 433 & 119 \\ 29.3 & 27.4 & 26 . \\ 15.8 & 14.8 & 15.1\end{array}$

$\begin{array}{rrr}1440 & 1520 & 1520 \\ 119 & 173 & 160\end{array}$

$\begin{array}{rrrrrrr}430 & 456 & 426 & 150 & 189 & 169 & 154 \\ 27 & 30 & 29 & 28 & 29 & 435 & 135 \\ 15 & 14 & 9.6 & 14 & 15 & 13 & 26 \\ & 0.3 & 15 & 0.3 & 0.3 & 0.2 & 0.3\end{array}$

ie (total)

0.01
0.05
0.05
0.05
0.03
0.005
0.025
0.1
0.0004
0.03
0.23
0.12
0.42

\begin{tabular}{lllllll}
9.5 & 8.48 & 0.7 & 7.9 & 7.7 & 7.2 & 8.02 \\
\hline
\end{tabular}

$\begin{array}{lllllll}255 & 270 & 265 & 250 & 270 & 250 & 250\end{array}$

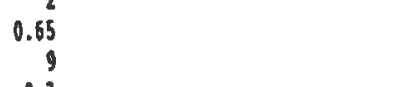

$\begin{array}{lllllll}0.04 & 0.02 & 0 & 0 & 0.01 & 0.05 & 0.01\end{array}$

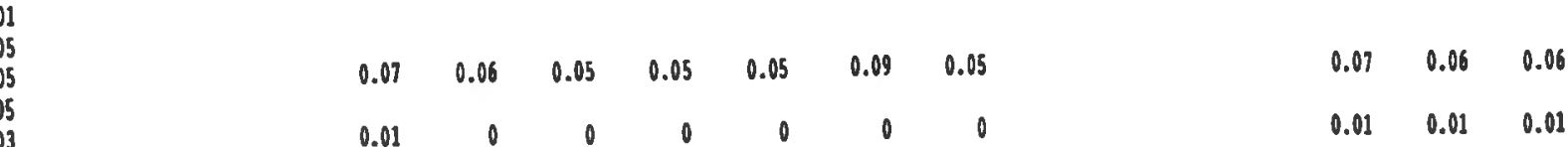

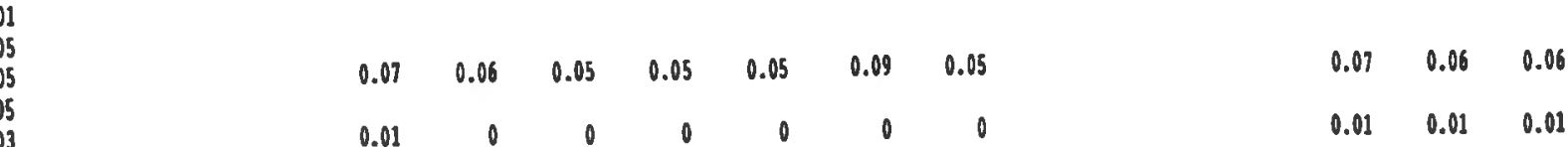

$\begin{array}{llll}0.51 & 0.5 & 0.5 & 0.5\end{array}$

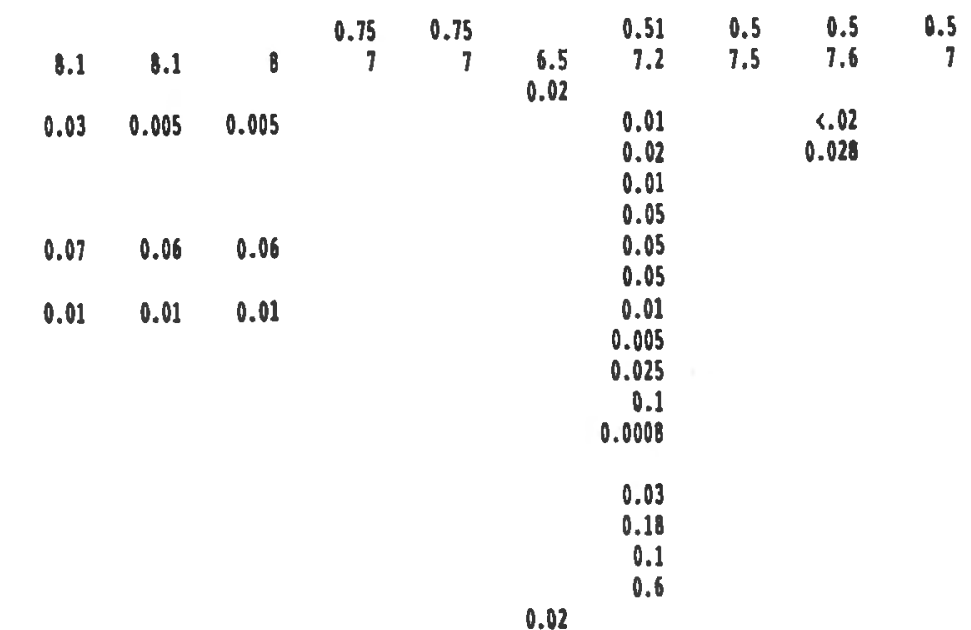

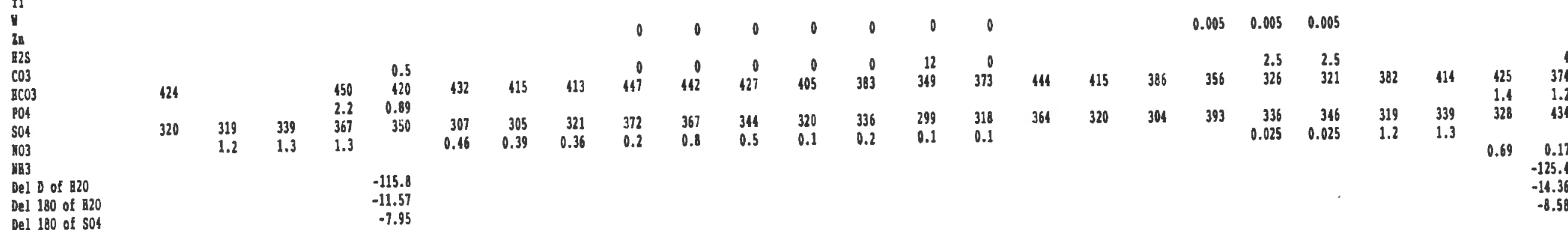

Del 1800 of 504

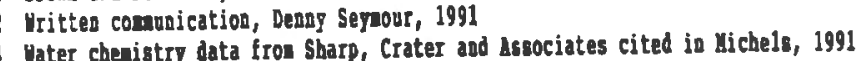


LHEMISTRY OF THERMAL AND NON-THERMAL WATET

IN THE ALVORD BASIN, 1953 - 1989

(continued)

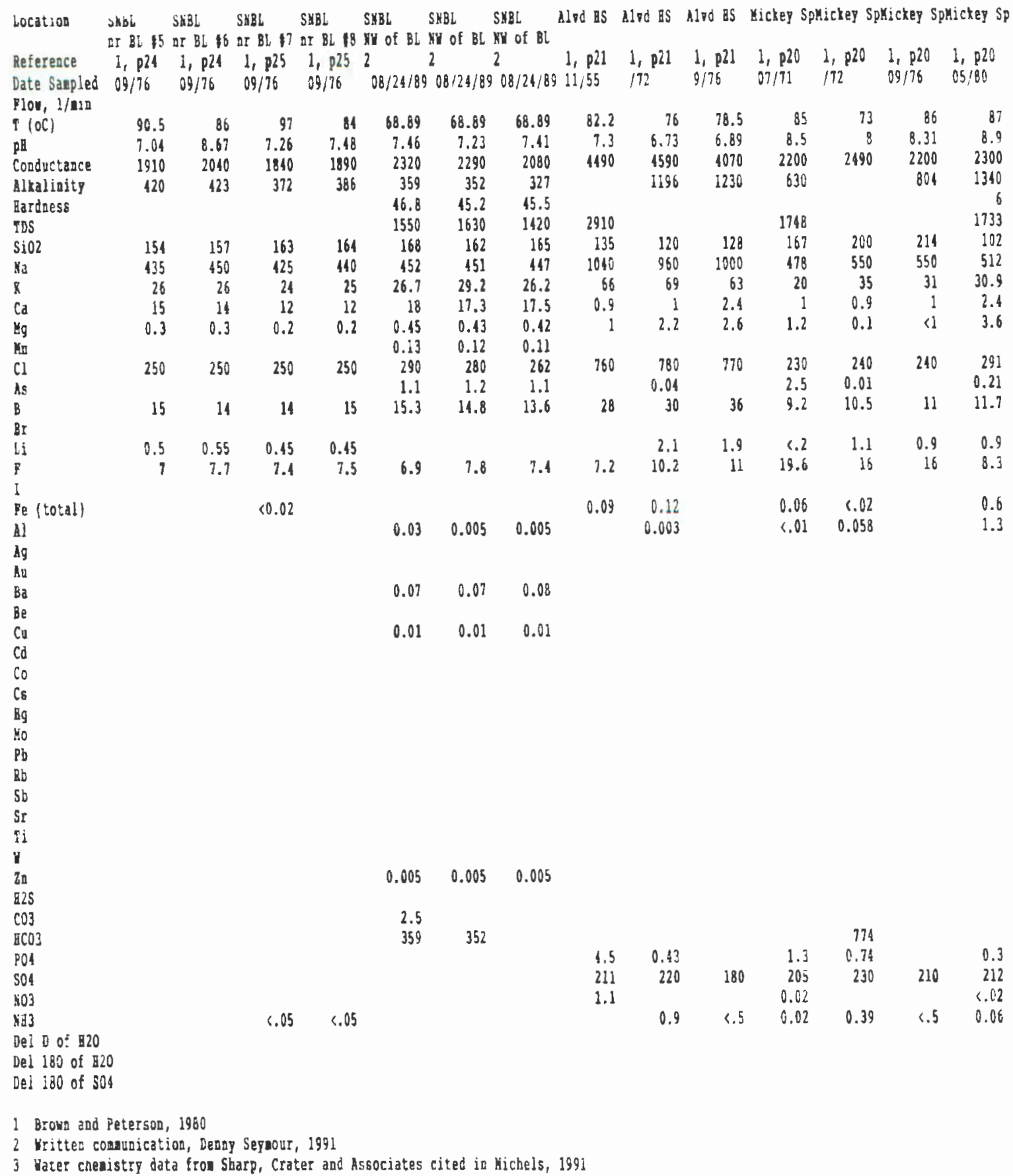


TABLE XV

FLUID-MINERAL EQUILIBRIA FOR COLD WATERS IN THE ALVORD BASIN

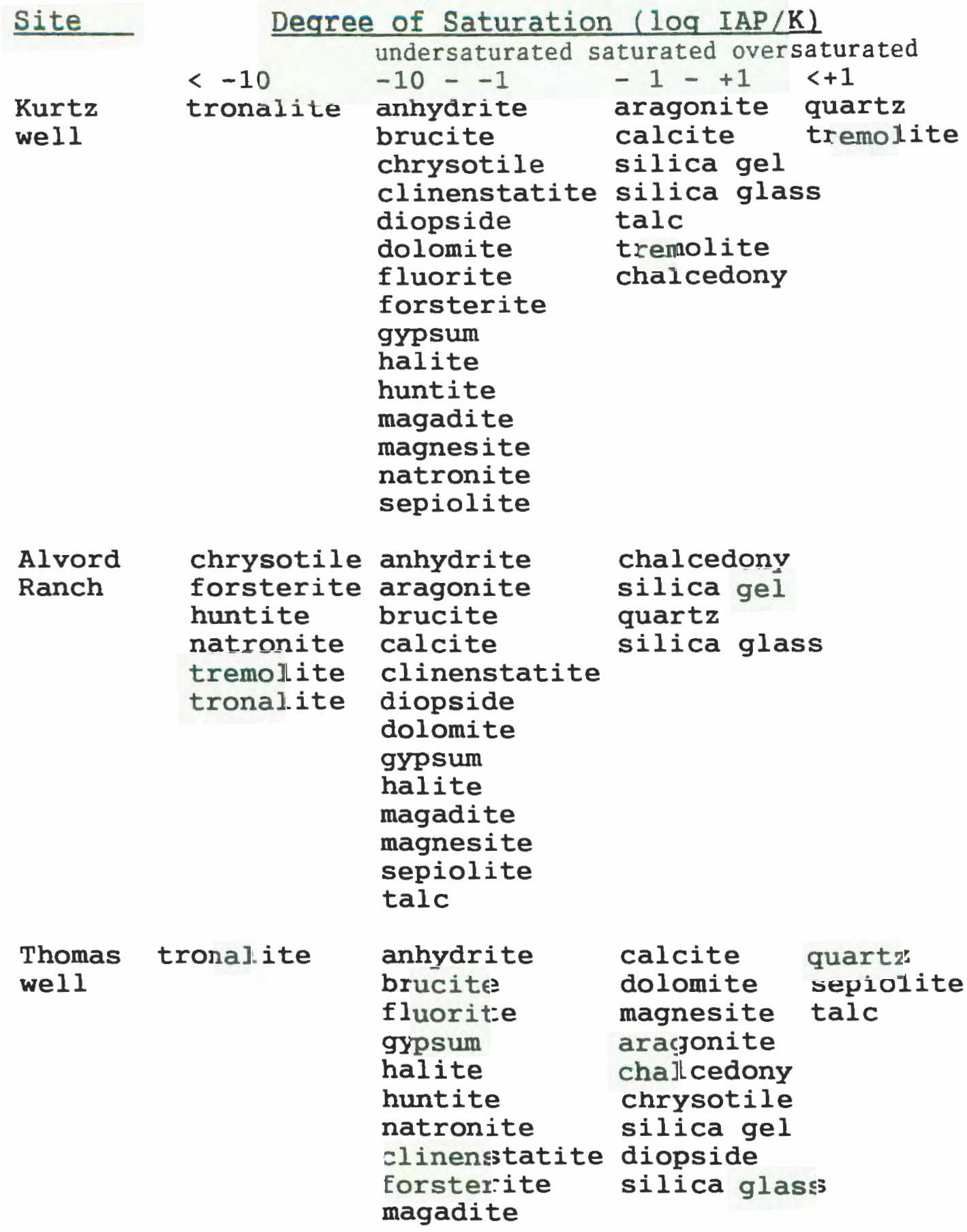

Saturation indices calculated using PCWATEQ. 
TABLE XVI

SATURATION INDICES ( $\log ($ IAP/Ksp))

FOR THERMAL FLUIDS

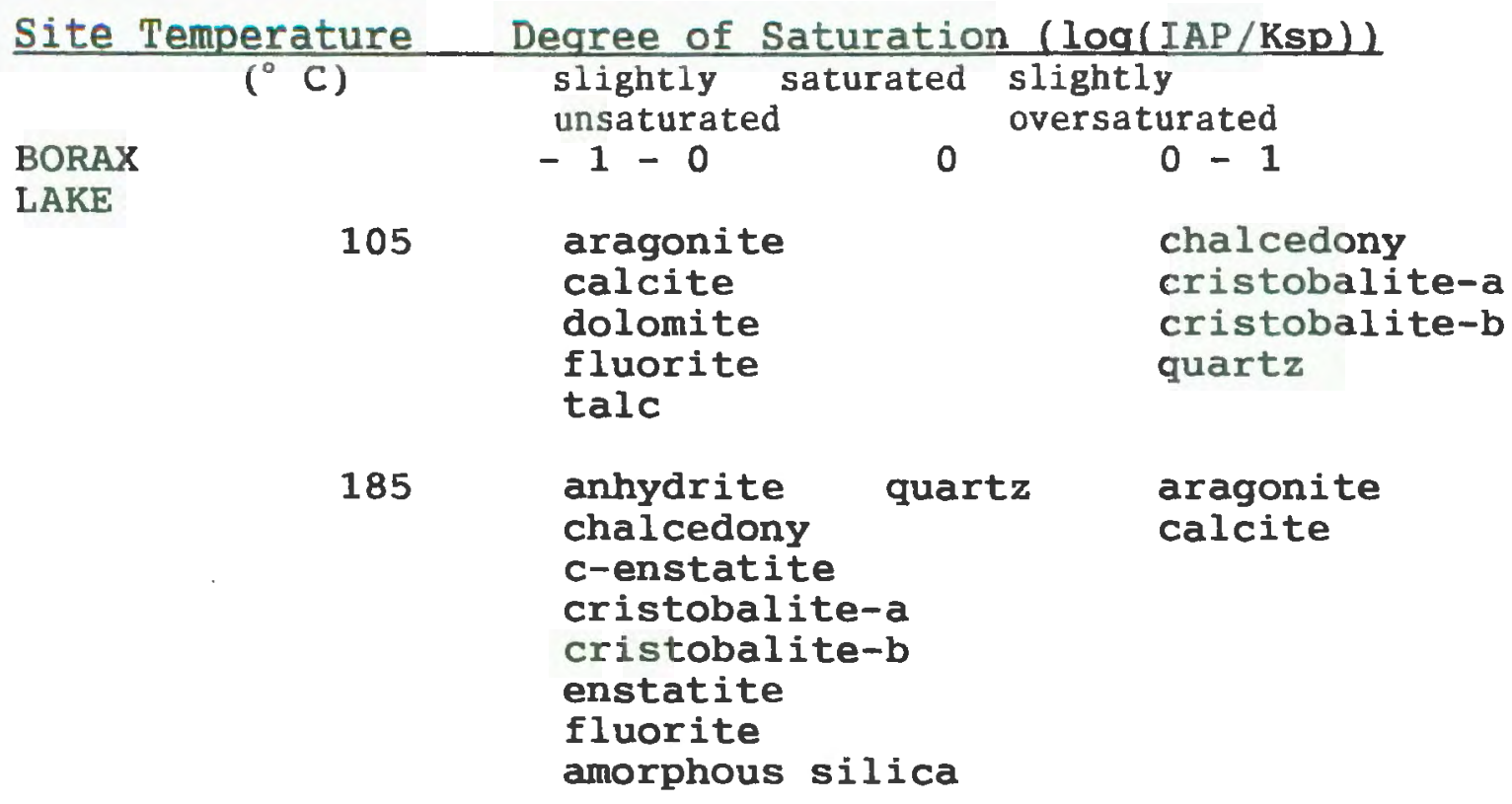

SPRINGS NORTH

OF BORAX LAKE

\begin{tabular}{|c|c|}
\hline 95.4 & $\begin{array}{l}\text { aragonite } \\
\text { barite } \\
\text { calcite } \\
\text { chalcedony } \\
\text { amorphous silica }\end{array}$ \\
\hline 152 & $\begin{array}{l}\text { anhydrite } \\
\text { barite } \\
\text { c-enstatite } \\
\text { cristobalite-a } \\
\text { cristobalite-b } \\
\text { enstatite }\end{array}$ \\
\hline
\end{tabular}

cristobalite-a cristobalite-b dolomite talc quartz

aragonite calcite chal cedony quartz

FLOWING WELL NORTHEAST OF BORAX LAKE

$\begin{array}{cl}58.6 & \begin{array}{l}\text { aragonite } \\ \text { barite } \\ \text { calcite }\end{array} \\ 180 & \begin{array}{l}\text { anhydrite } \\ \text { barite } \\ \text { brucite }\end{array}\end{array}$

chalcedony cristobalite-a cristobalite-b amorphous $\mathrm{SiO}_{2}$ aragonite calcite chalcedony 


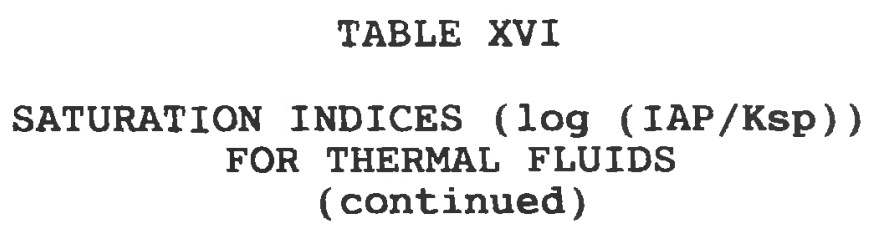

Site Temperature Degree of Saturation (log(IAP/KSP)) $\left.{ }^{\circ} \mathrm{C}\right)$ slightly saturated slightly unsaturated oversaturated
$-1-0$
0
$0-1$

FLOWING WELL NORTHEAST OF BORAX LAKE

180

cristobalite-a

c-enstatite cristobalite-b forsterite enstatite magnesite quartz

ALVORD HOT SPRINGS

77.6

aragonite

calcite

barite

fluorite magnesite amorphous silica

amorphous $\mathrm{SiO}_{2}$ chalcedony cristobalite-a cristobalite-b

quartz

160

barite chalcedony quartz cristobalite-a cristobalite-b magnesite amorphous silica

aragonite calcite c-enstatite enstatite sepiolite

MICKEY

SPRINGS

94.4

aragonite

barite amorphous silica

cristobalite-b calcite magnesite chalcedony c-enstatite cristobalite-a enstatite quartz

190 chalcedony cristobalite-b forsterite quartz amorphous silica

aragonite c-enstatite enstatite sepiolite

Saturation indices are calculated using SOLMINEQ.88 (Kharaka et al., 1988). 
TABLE XVII

GEOCHEMISTRY OF PORE FLUIDS FROM ALVORD LAKE

Depth (m)

Core 89-1

1.96-2.06

$3.01-3.13$

4. 44-4.56

Core $89-2$

$0.25-0.40$

1. 30-1. 45

2. $02-2.15$

3. 05-3.20

3. $90-4.05$

4. 70-4.85

Indian C.

Scoubes $C$

Depth (m)

Core 89-1

1. 96-2.06

$3.01-3.13$

4. 44-4.56

Core 89.2

$0.25-0.40$

1. 30-1. 45

2. $02-2.15$

3. $05-3.20$

3. $90-4.05$

$4.70-4.85$

Indian C.

Scoubes
Constituent (ppm)

$\mathrm{Na} \quad \mathrm{K} \quad \mathrm{Ca} \quad \mathrm{Mg}$ Fe Āl

$\begin{array}{llllll}7270 & 237 & 7.6 & 1.8 & 0.3 & <0.1 \\ 3000 & 41 & 4.3 & 1.4 & 0.1 & <0.1 \\ 2270 & 38 & 1.7 & <0.5 & <0.1 & <0.1\end{array}$

$\begin{array}{llllll}8440 & 1290 & 1.6 & <0.5 & 0.3 & <0.1 \\ 9960 & 253 & 3.8 & 0.6 & 0.4 & <0.1 \\ 11270 & 240 & 3.2 & 2.8 & <0.1 & <0.1 \\ 10940 & 203 & 3.3 & <0.5 & <0.1 & <0.1 \\ 7200 & 103 & 2.4 & 1.6 & <0.1 & <0.1 \\ 5500 & 95 & 3 & 2.2 & 0.2 & <0.1 \\ 19 & <1 & 24.3 & 10.1 & -- & <0.1 \\ 25 & <1 & 39 & 16.9 & 0.3 & <0.1\end{array}$

Cl

$\mathrm{S} \quad \mathrm{CO}_{3}{ }^{--} \mathrm{SiO}, \mathrm{Br} \quad \mathrm{F}$

B I

$\begin{array}{llllllll}4300 & 770 & 3180 & 108 & <20 & 27 & 79.6 & <0.5 \\ 2600 & 400 & 1520 & 95.0 & <20 & 28 & 36.6 & <0.5 \\ 2200 & 250 & 1140 & 73.3 & 70 & 22 & 27 & <0.5\end{array}$

$\begin{array}{llllllll}14000 & 190 & 9160 & 131 & 130 & 10 & 65.3 & <4.0 \\ 9000 & 1900 & 6270 & 88.2 & 90 & 30 & 154 & <2.0 \\ 14000 & 3200 & 5210 & 154 & 40 & 100 & 143 & <2.0 \\ 8000 & 2600 & 5200 & 103 & 110 & 80 & 128 & <2.0 \\ 6800 & 1100 & 3020 & 104 & 20 & 62 & 71.4 & <0.5 \\ 5200 & 670 & 2250 & 51.9 & 20 & 40 & 44.6 & <0.5 \\ 4 & 1 & 143 & 46.1 & <2.0 & <2.0 & <0.2 & <0.5 \\ 14 & 4.7 & 181 & 40.9 & 6 & <2.0 & <0.2 & \\ & & & & & & <0.5 & \end{array}$

Analyzed by J. C. Matthews, University of IIlinois (written communication, May 16, 1992). 